\title{
Recognition of high risk patients with acute myocardial ischemia
}

Citation for published version (APA):

de Zwaan, C. (1989). Recognition of high risk patients with acute myocardial ischemia. [Doctoral Thesis, Maastricht University]. Rijksuniversiteit Limburg. https://doi.org/10.26481/dis.19890420cz

Document status and date:

Published: 01/01/1989

DOI:

$10.26481 /$ dis. $19890420 \mathrm{cz}$

Document Version:

Publisher's PDF, also known as Version of record

\section{Please check the document version of this publication:}

- A submitted manuscript is the version of the article upon submission and before peer-review. There can be important differences between the submitted version and the official published version of record.

People interested in the research are advised to contact the author for the final version of the publication, or visit the DOI to the publisher's website.

- The final author version and the galley proof are versions of the publication after peer review.

- The final published version features the final layout of the paper including the volume, issue and page numbers.

Link to publication

\footnotetext{
General rights rights.

- You may freely distribute the URL identifying the publication in the public portal. please follow below link for the End User Agreement:

www.umlib.nl/taverne-license

Take down policy

If you believe that this document breaches copyright please contact us at:

repository@maastrichtuniversity.nl

providing details and we will investigate your claim.
}

Copyright and moral rights for the publications made accessible in the public portal are retained by the authors and/or other copyright owners and it is a condition of accessing publications that users recognise and abide by the legal requirements associated with these

- Users may download and print one copy of any publication from the public portal for the purpose of private study or research.

- You may not further distribute the material or use it for any profit-making activity or commercial gain

If the publication is distributed under the terms of Article $25 \mathrm{fa}$ of the Dutch Copyright Act, indicated by the "Taverne" license above, 


\section{RECOGNITION OF HIGH RISK PATIENTS}

WITH ACUTE MYOCARDIAL ISCHEMIA 



\title{
RECOGNITION OF HIGH RISK PATIENTS WITH ACUTE MYOCARDIAL ISCHEMIA
}

\author{
Proefschrift \\ ter verkrijging van de graad van doctor \\ aan de Rijksuniversiteit Limburg te Maastricht, \\ op gezag van de Rector Magnificus, Prof Dr FIM Bonke, \\ volgens het besluit van het College van Dekanen, \\ in het openbaar te verdedigen in de Aula der Universiteit \\ op donderdag, 20 april 1989 om 16.00 uur precies \\ door
}

Christoffel de Zwaan 
Promotor:

Beoordelingscommissie:
Prof Dr HJJ Wellens

\author{
Prof Dr RS Reneman (voorzitter) \\ Prof Dr BK Janevski \\ Prof Dr KJ Lie \\ Prof Dr OCKM Penn \\ Prof Dr EO Robles de Medina
}

CIP-GEGEVENS KONINKLIJKE BIBLIOTHEEK, DEN HAAG

Zwaan, Christoffel de

Recognition of high risk patients with acute myocardial ischemia / Christoffel de Zwaran ; [ill, by the author].

[S.I. : s.m.]. - Ill.

Proclschrift Mastrich - Met lit. opg.

ISBN 90-902)2749-1

SISO 605.12 UDC $616,12-072(043.3)$

Trefw: cardiologio.

This thesis has been prepared in the Department of Cardiology of the Academic Hospital, Maastricht, The Netherlands.

Financial support for the publication of this thesis was given by the Rescar Foundation,

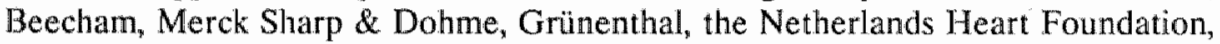
Bakken Research Center (Medtronic), 3M Riker, Ciba-Geigy, Hoechst, Bard, Kabi, Boehringer Ingelheim, Knoll. Their help is gratefully acknowledged.

Produktie: Datawyse - Maastricht

Druk: Krips Repro Meppel 


\section{CONTENTS}

\section{CHAPTER I}

Introduction

\section{CHAPTER II}

Characteristic electrocardiographic pattern indicating a critical stenosis high in left anterior descending coronary artery in patients admitted because of impending myocardial infarction. . . . . . . . . . . 3

\section{CHAPTER III}

Angiographic and clinical characteristics of patients with unstable angina showing an electrocardiographic pattern indicating critical narrowing of the proximal left anterior descending coronary artery. . . . 13

\section{CHAPTER IV}

Proximal left anterior descending coronary artery disease: are we able to recognize this "High-Risk" lesion.

\section{CHAPTER V}

Left ventricular wall motion in patients treated for unstable angina showing an electrocardiographic pattern indicating critical narrowing of the proximal left anterior descending coronary artery.

\section{CHAPTER VI}

Effects of thrombolytic therapy in unstable angina: clinical and angiographic results

\section{CHAPTER VII}

Clinical diagnoses in patients showing electrocardiographic changes as seen in patients with unstable angina and a critical narrowing of the proximal left anterior descending coronary artery. . . . . . . . 73

CHAPTER VIII

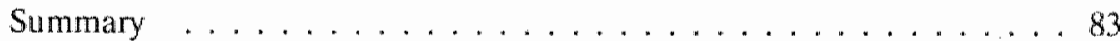

SAMENVATTING . . . . . . . . . . . . . . . 85

NAWOORD . . . . . . . . . . . . . . . . . . . . . . . 89

CURRICULUM VITAE $\ldots \ldots \ldots \ldots \ldots \ldots \ldots$ 



\section{INTRODUCTION}

Unstable angina has probably existed as long as mankind and has been related to myocardial ischemia for at least two hundred years. Until recently however the clinical. syndrome was poorly defined and the pathophysiology poorly understood.

Multiple clinical presentations have been placed under the heading of unstable angina, like: crescendo angina at rest, recent onset of angina at rest, crescendo angina on effort, recent onset of angina on effort, recent onset of angina both on effort and at rest, reappearence of rest and effort angina in a patient who had become asymptomatic after myocardial infarction.

Many names have been given to the different clinical presentations like: preinfarction angina, preinfarction syndrome, impending myocardial infarction, prinzmetal angina, variant angina, status anginosus, intermediate coronary syndrome, impending acute coronary occlusion, preliminary pain in coronary thrombosis, acute coronary insufficiency, cresendo angina, accelerated angina, progressive angina and unstable angina.

In the literature of the last decades, the one-year mortality rate for patients with these syndromes has been reported to range from 3 to 60 percent, while the incidence of the development of myocardial infarction should vary from $0-90$ percent. This variability suggests that different patient populations were included.

Because the pathophysiologic alterations during acute myocardial ischemia will determine the prognosis and the selection of appropriate treatment, it is clearly necessary that the clinician becomes informed about the pathophysiologic mechanisms and the proper definition of the various subcategories.

In the last years understanding of the pathophysiology of the various syndromes has been greatly enhanced by technical advances allowing radiographic and echocardiographic visualization of the coronary arteries, and estimation of myocardial blood flow and ventricular wall motion. These diagnostic tools play an important role in the selection of the proper treatment are used best however when there is thorough understanding of the clinical aspects of the syndrome.

We now appreciate that among the syndromes there is a prognostic spectrum: some patients are at a relatively low risk for infarction and death, whereas others are at a higher risk. Chapter II and III give the findings and characteristics of a subgroup of patients with unstable angina that can be identified as being at high risk. That population is characterized by an abnormal repolarization pattern in the precordial leads of the electrocardiogram and abnormal left ventricular function on contrast left ventricular angiography.

This elevated risk is caused by a lesion located proximally in the left anterior descending coronary artery. This vessel supplies a large area of the left ventricle. Evidence of the increased risk of such a lesion is given in Chapter IV.

Chapter $V$ shows that in those patients the abnormal electrocardiogram is accompanied by echocardiographic findings indicating an abnormal left ventricular contrac- 
tion and relaxation pattern. Both findings are usually transient if appropiate measures are taken to restore bloodflow to the threatened area.

Although our understanding of the pathophysiology of myocardial ischemia in general has increased during the past decade, the pathogenesis of the different forms of "unstable angina" is still incompletely understood. Several possible mechanisms have been proposed, including platelet aggregates, reducing the luminal orifice (usually in the region of an atheromatous plaque) or the release of vasoactive substances, which increase coronary artery smooth muscle tone. Evidence supporting the first mechanism is described in Chapter VI where the effects are reported of thrombolytic therapy in patients admitted to hospital with unstable angina showing ST-T segment changes.

Proximal left anterior descending coronary artery disease is not always found in patients presenting with the abnormal ECG suggestive of the "high LAD" lesion. The history, outcome of clinical examination and coronary angiographic and echocardiographic findings of 39 High LAD mimicry patients are described in Chapter VII, illustrating the importance of the clinical history in making the correct diagnosis and selecting appropiate treatment.

The purpose of this thesis is to stress the walue and necessity of risk stratification of patients with acute myocardial ischemia and to emphasize the importance of the electrocardiographic pattern suggestive of a high-risk lesion in the LAD.

In recent years increasing attention has been given to acute, frequently invasive, studies in patients admitted to hospital because of acute myocardial ischemia. The information presented indicates that a far less costly procedure like the recording and proper interpretation of the electrocardiogram can identify high-risk patients resulting in a more individualized and cost effective approach of these patients. 


\title{
Characteristic electrocardiographic pattern indicating a critical stenosis high in left anterior descending coronary artery in patients admitted because of impending myocardial infarction
}

\author{
Chris de Zwaan, M.D., Frits W.H. Bär, M.D., and Hein J.J. Wellens, M.D.
}

Am.Heart J. 1982; 103: 730-735

\begin{abstract}
$\overline{\text { ABSTRACT }}$
In patients admitted to the hospital because of unstable angina, a subgroup can be recognized that is at high risk for the development of an extensive anterior wall myo. cardial infarction. These patients, who show characteristic ST-T segment changes in the precordial leads on or shortly after admission, have a critical stenosis high in the left anterior descending coronary artery. Of 145 patients consecutively admitted because of unstable angina, 26 (18\%) showing this ECG pattern, suggesting that this finding is not rare. In spite of symptom control by nitroglycerin and beta blockade, 12 of 16 patients $(75 \%)$ who were not operated on developed a usually extensive anterior wall infarction within a few weeks after admission. In view of these observations, urgent coronary angiography and, when possible, coronary revascularization should be done in patients with unstable angina who show this ECG pattern.
\end{abstract}

\section{INTRODUCTION}

The management of patients admitted to the coronary care unit because of ischemic chest pain of recent onset or sudden exacerbation of chronic stable angina not result. ing in immediate myocardial infarction has been a subject of intensive discussion in recent years. In most hospitals, the usual approach is to treat such patients medically with nitroglycerin and beta blockade. Calcium antagonists are given to those suspected of having Prinz-metal's angina. Only patients not responding within a few days to this type of management are considered candidates for coronary angiography to identify those who can and should be helped by coronary bypass surgery or coronary angioplasty (13).

We believe that among patients at risk of an impending myocardial infarction, a subgroup can be recognized who do poorly with conservative management, even though initially they seem to respond well to treatment. This subgroup, for whom the value of more aggresive management should be evaluated, is described here. 


\section{MATERIAL AND METHODS}

Of 145 patients consecutively admitted because of an impending myocardial infarction, 26 had or developed within 24 hours after admission abnormal ST segments and negative $T$ waves in the anterior chest leads without changes in the QRS complex.

Impending myocardial infarction was defined as crescendo angina of recent onset, sudden worsening of stable angina, or crescendlo postinfarction angina developing after an initiall asymptomatic period.

As illustrated in Fig.1, all 26 patients showed a typical pattern of the ST-T segment in leads $V_{2}$ and $V_{3}$ consisting of an isoelectric or minimally elevated $(1 \mathrm{~mm})$ takeoff of the ST segment from the QRS complex, a concave or straight ST segment passing into a negative $T$ wave at an angle of 60 to 90 dlegrees, and a symmetrically inverted $T$ wave.

Twenty-five of the 26 patients also had a typical pattern in lead $V_{1}$ : an isoelectric or minimally elevated $(1 \mathrm{~mm})$ takeoff of the ST segment and a concave or straight ST segment passing into the first part of the $T$ wave at an angle of approximately 135 degrees, followed by T wave inversion. In addition, 22 had an ST-T segment pattern in lead $V_{4}$, and sometimes $V_{5}$ and $V_{6}$ consisting of a takeoff of the ST segment from the QRS complex below the isoelectric line and a convex ST segment passing into a negative T wave at an angle of about 120 degrees with a deep symmetrically inverted T wave (Fig. 1, B).

In 13 patients this ECG pattern was present on admission; in the remaining 13 it developed within 24 hours after admission. No pathologic Q waves or QS complexes were present or developed in the precordial leads. Patients with complete right bundle branch block, incomplete left bundle branch block, or criteria for probable or definite left or right ventricular hypertrophy were excluded. Also excluded were patients showing a loss in initial $\mathbb{R}$ wave voltage in lead $V_{1}$ or disappearance of $Q$ waves in lead $V_{5}$ or $\mathrm{V}_{6}$.
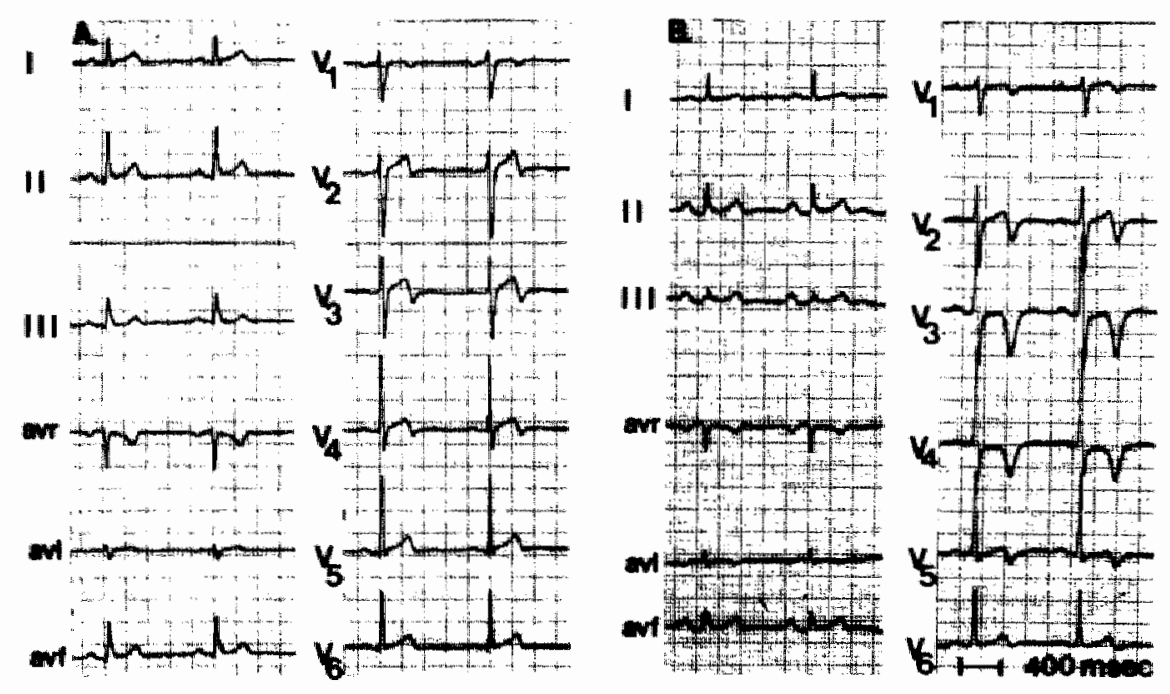

FIGURE 1. ECG patterns in precordial leads of the patients reported. Pattern A was found in four patients; pattern $B$, in 22 patients. See text. 
Serial enzyme values for creatinine phosphokinase (CPK), serum glutamic oxaloacetic transaminase (SGOT), and serum lactic dehydrogenase (SLDH) were determined in all patients every 8 hours for 3 consecutive days after admission. Twenty-two patients had normal serial enzyme values (CPK, SGOT, SLDH). Four patients showed a minor rise in serial enzyme levels, not exceeding twice the upper limit of normal.

The patients ranged in age from 38 to 81 years, with a mean of 58 years. There were 18 men and eight women. Seven patients had a history of hypertension, and three had suffered a previous myocardial infarction.

We divided our patients into two groups: group A (patients 1 to 9) had these ECG findings before the prognostic significance was realized; group B (patients 10 to 26) showed the same ECG abnormalities after the prognostic significance was suspected.

Coronary angiography was performed in multiple projections by using the Judkins technique. A stenosis in a coronary artery had to affect at least $70 \%$ of the luminal diameter in any view to be considered an important lesion. Abnormalities in left ventricular wall motion were assessed from the 30-degree right anterior oblique and the 60degree left anterior oblique views. From these projections, the left ventricular silhouette was divided into seven segments (anterobasal, anteroseptal, anterolateral, apical, posterobasal, diaphragmatic and posterolateral). The ventricular ejection fraction was determined from the 30 -degree right anterior oblique left ventriculogram. The catheterization variables were interpreted in conference by at least two of the same three experienced angiographers.

\section{RESULTS}

\section{Case History}

The tracings shown in Fig.2 were obtained from a 45-year-old man who experienced ischemic chest pain (New York Heart Association class II) for 4 weeks before admission. Tracing A was recorded on admission. The maximal serum enzyme values were not diagnostic for acute myocardial infarction: CPK $106 \mathrm{U} / \mathrm{L}$, SGOT $26 \mathrm{U} / \mathrm{L}$, SLDH 343 U/L (upper limit of normal: CPK $200 \mathrm{U} / \mathrm{L}$, SGOT $40 \mathrm{U} / \mathrm{L}$, SLDH $400 \mathrm{U} / \mathrm{L}$ ). The patient was treated with a beta-blocking agent and long-acting nitroglycerin and became symptom free. Tracing B was recorded 23 hours after admission at a time when the patient had no complaints. During the next 3 days, the ECG returned to "normal", and the patient remained symptom free and was mobilized. On the ninth day after admission, the patient had an attack on chest pain that did not respond to nitroglycerin (tracing C). He subsequently developed an extensive anterior wall infarction, complicated by severe pump failure and died 12 hours later.

At autopsy, the normal-sized heart showed an extensive fresh anteroseptal infarction. At the bifurcation of the left coronary artery into the left anterior descending (LAD) and the circumflex branch, there was a complete occlusion by a fresh thrombus, seated on a severely narrowed arteriosclerotic artery. The right coronary artery showed no significant stenoses. 

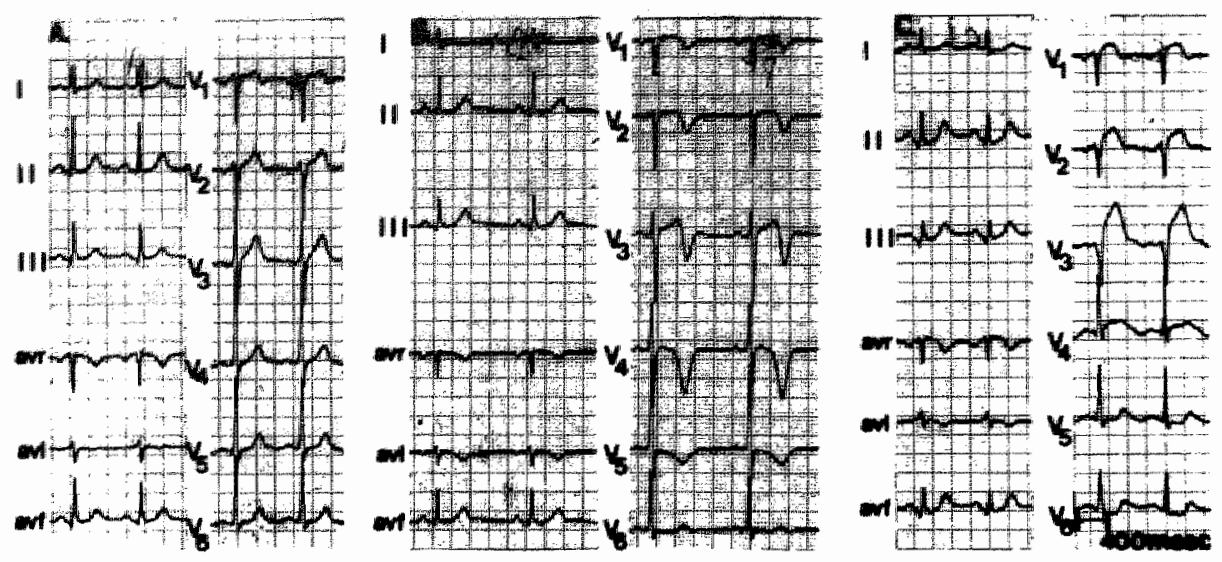

FIGURE 2, ECG palterns from patient 2. A, ECG recorded on admission. B, ECG recorded 23 hours later. The patient was without pain in the interwal between tracings $A$ and $B$. Four days after admission, the tracings were like those in A. C, ECG made on day 9 following admission. At that time, the patient suffered from severe chest pain and did not respond to nitroglycerin. He died from progressive pump failure 12 hours later.

\section{Clinical Data}

All 26 patients fulfilled the criteria for unstable angina (Table 1). Eighteen patients had crescendo angina of recent onset (range 1 day to 4 weeks; mean 16 days). Five patients had sudden worsening of previously stable angina. The remaining three had developed crescendo postinfarction angina after an initial asymptomatic period; their infarctions had occurred 5 weeks, 7 months, and 3 years, respectively, before this admission.

In all 26 patients, chest pain was alleviated with drug therapy: 25 were administered long-acting nitroglycerin and a beta-blocking agent; one patient, with a typical history of Prinzmetal's angina, received a calcium antagonist.

The prognostic significance of the ECG pattern was not initially recognized, which may, in part, explain why eight of the first nine patients (group A) developed a myocardial infarction. In all, 12 patients (eight in group $A$ and four in group $B$ ) developed a myocardial infarction (Table 2), 11 within 39 days (range 4 to 38 , mean 21 days) and one patient 307 days after the onset of complaints of impending infarction. The maximal SGOT value ranged in nine patients from 56 to $607 \mathrm{U} / \mathrm{L}$ (mean $315 \mathrm{U} / \mathrm{L}$ ). Two patients died within 12 hours. One patient's ECG showed an anteroseptal infarction on the first outpatient clinic visit 23 days after admission for an impending infarction. Enzyme values were normal at that time. Table 2 gives data on the size of the infarctions (the maximal SGOT value) and on complications.

In addition to the two patients (patients 2 and 6 ) who died of congestive heart failure within 12 hours after infarction, one patient died 6 weeks after infarction, following aneurysmectomy performed because of intractable ventricular tachycardia. 
TABLE 1. Characteristics of the 26 patients studied

\begin{tabular}{|c|c|c|c|c|c|c|c|c|}
\hline \multirow[b]{3}{*}{ Patient } & \multirow[b]{3}{*}{$\operatorname{Sex}$} & \multirow[b]{3}{*}{$\begin{array}{l}\text { Age } \\
\text { (yr) }\end{array}$} & \multicolumn{3}{|c|}{ Past medicall history } & \multirow{2}{*}{\multicolumn{3}{|c|}{ Clinical course }} \\
\hline & & & \multirow[b]{2}{*}{ HT } & \multirow{2}{*}{$\begin{array}{l}\text { On } \\
\text { Previous } \\
\text { MI(location) }\end{array}$} & \multirow{2}{*}{$\begin{array}{l}\text { anset or exacablyation } \\
\text { of chest pain } \\
\text { (wk) }\end{array}$} & & & \\
\hline & & & & & & AMI & Cath & $\mathrm{CABG}$ \\
\hline 1 & M & 67 & + & - & 1 & + & + & \\
\hline 2 & M & 45 & - & - & 4 & $+\rightarrow+1$ & & \\
\hline 3 & $\mathbb{F}$ & 68 & + & - & $1 / 2$ & $+x \rightarrow H$ & th & \\
\hline 4 & M & 61 & - & - & 4 & & + & + \\
\hline 5 & $\mathbb{F}$ & 81 & - & - & 5 & + & & \\
\hline 6 & $\mathbf{M}$ & 75 & - & 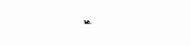 & 2.5 & $+\rightarrow t$ & & \\
\hline 7 & $\mathbf{M}$ & 69 & - & - & 2.5 & + & & \\
\hline 8 & M & 43 & + & - & 0.5 & + & & \\
\hline 9 & M & 65 & - & - & 1 & + & & \\
\hline 10 & $\mathrm{M}$ & 43 & the & Anterior & $<6$ & & + & + \\
\hline 11 & $\mathrm{~F}$ & 64 & + & $*$ & 0.5 & & $-(r)$ & \\
\hline 12 & $\mathbf{F}$ & 58 & - & - & 4 & & + & - \\
\hline 13 & $\mathbf{F}$ & 54 & - & - & 2 & & + & $+w$ \\
\hline 14 & $\mathbf{M}$ & 41 & - & - & 2 & & + & + \\
\hline 15 & $\mathrm{M}$ & 49 & - & . & 2 & & $H$ & + \\
\hline 16 & $\mathbf{F}$ & 59 & - & - & 4 & & + & + \\
\hline 17 & $\mathbb{F}$ & 38 & - & - & 0.33 & & + & + \\
\hline 18 & $M$ & 60 & - & Inferior & 1.5 & & $(\mathbf{r})$ & \\
\hline 19 & $\mathbf{M}$ & 70 & - & - & 1.5 & + & $-(a)$ & \\
\hline 20 & $\mathbf{M}$ & 63 & - & - & 4 & + & $-(r)$ & \\
\hline 21 & $\mathrm{~F}$ & 69 & + & - & 2 & & (a) & \\
\hline 22 & $\mathrm{M}$ & 44 & + & - & 2 & & + & + \\
\hline 23 & $\mathrm{M}$ & 60 & $\sim$ & - & 0.14 & + & $-(r)$ & \\
\hline 24 & $\mathrm{M}$ & 54 & . & - & 4 & & + & \\
\hline 25 & $\mathrm{M}$ & 55 & - & 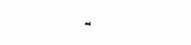 & 3 & & + & 4 \\
\hline 26 & $\mathrm{M}$ & 44 & - & Inferior & 0.33 & + & $-(\mathbb{r})$ & \\
\hline
\end{tabular}

AMI, Acute myocardial infarction; $\mathrm{CABG}$, coronary artery bypass graft; Cath, cardiac catheterization;

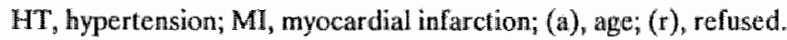

$+=$ present; - = absent; $\hat{\dagger}=$ death.

\section{Catheterization Findings}

Following our experience with the first nine patients, we performed early cardiac catheterization and coronary angiography in 10 of the next 17 patients within 1 to 8 days (mean 4 days) after admission. Two patients were considered ton old for the procedure, and five patients refused catheterization. Including three of the first nine patients, a total of 13 catheterizations were done. 
TABLE 2. Chatracteristics of 12 patients who developed acute myocardial infarction

\begin{tabular}{|c|c|c|c|c|c|}
\hline Patient & $\begin{array}{l}\text { Time between } \\
\text { admutision and } \\
\text { inflarction(days) }\end{array}$ & $\begin{array}{l}\text { Time from onisel } \\
\text { of complaints to } \\
\text { infarction(days) }\end{array}$ & $\begin{array}{l}\text { Maximum } \\
\text { SGOT } \\
\text { (U/L) }\end{array}$ & Complications & Antopsy \\
\hline 1 & 7 & 14 & 358 & $\begin{array}{l}\text { CRBBB,pericarditis } \\
\text { CHF,AF }\end{array}$ & \\
\hline 2 & 9 & 37 & $?$ & $\mathrm{VT}_{8} \mathrm{CHF}$, & $\begin{array}{l}\text { Complete } \\
\text { occlusion } \\
\text { bifurcation LCA }\end{array}$ \\
\hline 3 & 8 & 11 & 390 & $\begin{array}{l}\text { CRBBB,CHF,VT } \\
\text { aneurysmectomy, } \dagger\end{array}$ & \\
\hline 5 & 1 & 36 & 56 & & \\
\hline 6 & 22 & 39 & $?$ & $\mathrm{CHF}, t$ & $\begin{array}{l}\text { Complete } \\
\text { occllusion } \\
\text { proximal LAD }\end{array}$ \\
\hline 7 & 290 & 307 & 420 & $\mathrm{AF}$ & \\
\hline 8 & 5 & 8 & 350 & & \\
\hline 9 & 5 & 12 & 131 & & \\
\hline 19 & 23 & 33 & $?$ & & \\
\hline 20 & 3 & 31 & 607 & Pericarditis, $\mathrm{CHF}, \mathrm{AF}$ & \\
\hline 23 & 9 & 10 & 328 & & \\
\hline 26 & 2 & 4 & 194 & & \\
\hline
\end{tabular}

$\mathrm{AF}$, Atrial fibrillation; $\mathrm{CHF}$, congestive heart failure; CRBBB, complete right bundle branch block; LAD, left anterior descending coronary artery; LCA, left coronary artery; SGOT, serum glutamic oxaloacetic transaminase; VT, ventricular tachycardia.

$\dagger=$ death.

Twelve patients - three in group $\mathrm{A}$ and nine in group $\mathrm{B}$ - had coronary artery disease. Of those in group $\mathrm{A}$, two had already suffered a myocardial infarction and one patient was catheterized after the significance of the ECG pattern was realized. The two in group A (patients 1 and 3 ) who had suffered a myocardial infarction and were catheterized showed a complete occlusion of the LAD artery proximal to the first septal branch. One patient in group B (patient 12), whose ECG was like that in Fig. 1, B, had normal coronary arteries and a prolapse of the posterior leaflet of the mitral vallve. The hemodynamic and angiographic findings in the one patient in group A who had not developed myocardial infarction and the 10 patients in group B are given in Table 3 . As shown, in all patients with coronary artery disease, a significant stenosis ( $\geq 90 \%$ ) was present in the LAD artery. In seven, the stenosis was located proximal to the first septal branch, and in three, between the first and second septal branches. In all 10 patients the ejection fraction was normal or near normal. Except in two patients, the left ventricular end-diastolic pressure was normal. Hypokinetic segmental wall motion 
TABLE 3. Hemodynamic and angiographic findings in one patient from group $A$ and 10 parients from group B

\begin{tabular}{lccll}
\hline Patient & $\begin{array}{c}\text { LVEDP } \\
(\mathrm{mm} \mathrm{Hg})\end{array}$ & $\begin{array}{c}\text { Ejection } \\
\text { fraction } \\
(\%)\end{array}$ & $\begin{array}{c}\text { Areas of hypokinetic } \\
\text { wall motion }\end{array}$ & $\begin{array}{l}\text { Sienosis } \\
(290 \%)\end{array}$ \\
\hline 4 & 18 & 70 & AP,AL & LAD \\
10 & 20 & 59 & AS,AP,AL & LAD,RCA \\
$12 *$ & 14 & 71 & - & - \\
13 & 6 & 62 & AP,AL & LAD \\
14 & 8 & 65 & AP,AL & LAD \\
15 & 12 & 73 & AP & LAD \\
16 & 12 & 71 & AP & LAD,RCA \\
17 & 10 & 71 & AP & LAD,Circ \\
22 & 8 & 54 & AS,AP,AL & LAD,Circ, RCA \\
24 & 10 & 74 & AP & LAD \\
25 & 8 & 77 & AP & LAD \\
\hline
\end{tabular}

AL, Anterolateral; AP, apical; AS, anteoseptal, Circ, circumflex coronary artery; $L A D$, left anterior descending coronary artery, LVEDP, left ventricular end-diastolic pressure; RCA, right coronary artcry.

*Prolapsed mitral valle.

in the area supplied by the LAD branch was seen in all 10 patients. No complications occurred during catheterization.

Of the 11 patients without myocardial infarction studied by coronary angiography, nine underwent coronary bypass surgery 17 to 56 days (average 33 days) after the onset of complaints and 2 to 28 days (average 14 days) after admission to the hospital. All patients received grafts to the $\mathrm{LAD}$ artery. In four patients two vessels, in two patients three, and in one patient four vessels were bypassed. All patients became symptom free. The mean follow-up period was 7.5 months. Postoperatively, seven patients showed a normal ST-T segment in the precordial leads, and two patients had negative $T$ waves in the precordial leads. The abnormal ST-T segments (Fig. 1) disappeared in all cases. One patient will be operated on shortly.

\section{Duration of ST-T Segment Characteristics}

Nine of the 12 patients who developed a myocardial infarction showed the reported ST-T segment abnormalities during the last days preceding infarction. Of the nine patients operated on, three still had the same abnormalities the day before surgery, five had nonspecific ST-T segment changes, and one patient's ECG was normal. Of the three patients in group B who did not develop a myocardial infarction and who were not catheterized, two still exhibited the ST-T segment abnormalities 3 and 9 months, respectively, after admission. In the patient with a history of Prinzmetal's angina, the ECG became normal after treatment with a calcium antagonist. The ST-T abnormali- 
thes in the patient with mitral walve prolapse were still present on an outpatient clinic visit 10 months after admission.

\section{DISCUSSION}

Our study indicates that certain ST segment and $T$ wave abnormalities in the anterior chest leads, in the setting of an impending myocardial infarction, are suggestive of extensive ischemia of the anterior wall, most likely caused by a critical lesion in the proximal portion of the LAD artery. Twenty-six of $145(18 \%)$ patients consecutively admitted because of recent onset or exacerbation of chronic stable angina exhibited these ECO changes, indicating that this is not a rare finding. Our observations suggest that this group of patients is at high risk for the subsequent development of an extensive myocardial infarction of the anterior wall. Twelve of the 16 patients not investigated by coronary angiography developed a usually extensive anterior wall infarction. In 11, the myocardial infarction occurred within 1 to 23 days (mean 8.5 days) after admission.

Of interest is the difference between the time from admission to infarction in the 11 patients who suffered a myocardial infarction (mean 8.5 days) and the interval from admission to bypass surgery in the nine patients who were operated on (mean 14 days). One possible explanation for the lack of infarction in the latter group could be the restriction in physical activities imposed on them following catheterization.

Patients showing the type of ST-T segment abnormalities described usually are classified as having either nontransmural or subendocardial ischemia (in the absence of enzyme changes) or a subendocardial infarction of the anterior wall (in the presence of an enzyme rise). In recent years, it has been stressed that the 1-year prognosis of patients with subendocardial infarction is no different from that of patients with a transmural infarction (4-7). Our data suggest that the poor prognosis of patients with subendocardial infarction may be the result of the inclusion in those series of the type of patients described here. In our patients, the control of symptoms by drug therapy was not indicative of a more benign course. With regard to the ST-T segment abnormalities, we could not identify a particular sign having prognostic significance, such as the degree of the ST segment elevation in lead $V_{2}$, the shape of the ST segment in leads $V_{2}$ and $V_{3}$, the depth of the inverted T waves, or the duration of the ST-T segment abnormalities.

We do not have an explanation for the mechanism of these ST-T segment abnormalities. Although the possibility of a subendocardial infarction cannot be excluded, perhaps the ECG manifestations of persistent myocardial abnormalities may be the consequence of brief periods of severe ischemia not associated with necrosis $(8,9)$. As would be expected, the ECG changes do not predict the presence or absence of significant stenoses in other coronary arteries.

In one patient (patient 12) ECG abnormalities were present in the absence of coronary artery disease. Table 3 shows that a normal or near normal ejection fraction was found in patients with a critical LAD lesion who underwent catheterization and did not develop myocardial infarction. Only two of these had a left ventricular end-diastolic pressure of more than $14 \mathrm{~mm} \mathrm{Hg}$. All 10 had areas of hypokinesis (but not akinesis or 
dyskinesis) in the anterior wall. Nitroglycerin was not routinely given during the catheterization. Because not all the patients were recatheterized after surgery, information about the reversibility of these wall motion abnormalities is not available.

\section{$\overline{\text { CONCLUSIONS }}$}

It is of importance that the time course between complaints, ST-T segment abnormalities, and subsequent myocardial infarction allows early coronary angiography in the majority of patients showing these ECG abnormalities. We conclude that in patients admitted with chest pain and with the ECG pattern described who have no or slight myocardial damage as reflected by enzyme values, urgent coronary angiography should be performed to identify candidates for early revascularization. The morbidity and mortality of cardiac catheterization and surgery can be expected to be less than that of an extensive myocardial infarction of the anterior wall (10). The long-term benefit of bypass surgery in these patients needs further evaluation.

\section{REFERENCES}

1. Plotnick GD, Conti CR:

Unstable angina: Angiography, short- and Jong-term morbidity, mortality and symptomatic status of medically treated patients. Am.J.Med. 63: 870, 1977.

2. National Cooperative Study Group:

Unstable angina pectoris: National Cooperative Study Group to compare surgical and medical therapy. II. In-hospital experience and initial follow-up results in patients with one-, two- and three-vessel disease. Am.J.Card. 42: 839, 1978.

3. Kolibask AJ, Goodenow JS, Busk CA, Tetalman MR, Lewis RP: Improvement of myocardial perfusion and left ventricular function after coronary artery bypass grafting in patients with unstable angina. Circulation 59: 66, 1979.

4. Rigo P, Murray M. Taylor DR, Weisfeldt ML, Strauss HW, Pitt B:

Hemodynamic and prognostic findings in patients with transmural and non-transmural infarction. Circulation 51: 1064, 1975.

5. Madias JE, Gorlin R:

The myth of "mild" myocardial infarction. Ann.Intern Med. 86: 347, 1977.

6. Madigan NP, Rutlerford BD, Frye RL:

The clinical course, early prognosis and coronary anatomy of subendocardial infarction. Am.J.Med. 60: 634, 1976. 
7. Szklo M, Goldberg R, Kennedy HL, Tonascia JA:

Survival of patients with non-transmural myocardial in farction: A populationbased study. Am.J.Cardiol. 42: 648, 1978.

8. Kloner RA, DeBoer LWV, Darsee JR, Ingwal JS, Braunwald E:

Persistent myocardial abnormalities following brief periods of temporary coronary occlusion not associated with necrosis. Circulation 62 (suppl. III): 80, 1980.

9. DeBoer LWV, Kloner RA, Ingwal JS, Hale S, Dinello A, Braunwald E:

ATP resynthesis and purine metabolism after brief ischemia and prolonged reperfusion. Circulation 62 (suppl. III): 176, 1980.

10. Kennedy JW, Kaiser GC, Fisher LD, Maynard C, Fritz JK, Myers W, Mudd JG, Ryan TJ, Coggin J:

Multivariate discriminant analysis of the clinical and angiographic predictors of operative mortality from the Collaborative Study in Coronary Artery Surgery (CASS). J.Thorac. Cardiovasc.Surg. 80: 876, 1980. 


\section{Angiographic and clinical characteristics of patients with unstable angina showing an electrocardiographic pattern indicating critical narrowing of the proximal left anterior descending coronary artery.}

Chris de Zwaan MD, Frits W Bär MD, Johan HA Janssen MD, Willem RM Dassen Ph.D, Pedro Brugada MD, Olaf CKM Penn MD, Hein JJ Wellens MD.

Am.Heart $\mathrm{J}$. in press

\section{$\overline{\text { ABSTRACT }}$}

One hundred and eighty of 1260 patients consecutively admitted to the hospital because of unstable angina pectoris had the typical ST-T segment changes suggestive of a critical stenosis in the proximal left anterior descending coronary artery (LAD). In 108 patients the ECG abnormalities were present at the time of admission. In the remaining 72 patients they developed shortly thereafter. The difference between these 2 groups was a longer duration of anginal complaints in the former (mean 2.3 days).

Results of coronary angiography, performed a mean of 4.6 days after the last attack of chest pain, showed $50 \%$ of more narrowing in the proximal LAD in all patients. Thirty-three patients had complete occlusion of the LAD and 75 had collateral circulation to the LAD.

Results of left ventricular angiography showed abnormal systolic left ventricular wall motion in 137 patients and normal systolic motion in the remaining 43 patients. The difference between these 2 groups was a shorter mean time interval between the last attack of chest pain and angiography in the former group $(p<0.001)$. Twenty-four patients had only abnormal diastolic wall motion.

Twenty-one patients had a small increase in the creatine kinase level at the time of admission. Fifteen patients (nine before and 6 during early revascularization) had an anterior wall myocardial infarction in the hospital; these patients had a patent but severely narrowed LAD and a low incidence of collateral circulation to the LAD. One hundred fifteen patients underwent revascularization shortly after admission. Of 56 patients treated medically; 26 eventually underwent revascularization (a mean of 8 months and 15 days after the initial admission).

During the follow-up period (mean 4.2 years) 8 of the 30 patients treated medically died of a cardiac cause. There was one cardiac death among the 136 patients discharged after revascularization. During follow-up most of the patients showed normalization of the ECG and left ventricular wall motion abnormalities, suggesting hibernation or stunning of the myocardium as the mechanism of these abnormalities. 
We conclude that in risk stratification of patients with unstable angina, the ECG is of great value for recognizing a subset of patients with a proximal LAD lesion having a poor prognosis because of a substantial area of jeopardized myocardium. Early cardiac catheterization is indicated so that appropriate therapy can be selected.

\section{INTRODUCTION}

In 1982 we reported on a typical electrocardiographic (ECG) pattern pointing to a critical reduction in flow in the left anterior descending coronary artery (LAD) in patients admitted to hospital, because of unstable angina (1). These patients characteristically had abnormal ST segments and negative $T$ waves in the precordial leads $V_{2}$ and $V_{3}$ in the absence of pathologic $\mathrm{Q}$ waves. Similar observations were made by Haines et al (2) and Boden et al (3). The ECG abnormalities were frequently only present during a limited period of time.

Considering the importance of the $\mathrm{LAD}$ in perfusing a large area of the left ventricular myocardium, awareness of this electrocardiographic pattern is helpful in identifying patients with unstable angina who are at risk for losing a considerable amount of myocardial tissue.

In this article we report our findings in a prospective study of 180 consecutive patients with unstable angina who had this ECG pattern.

\section{METHODOLOGY}

\section{Patient selection}

From July 1, 1980 to December 31, 1985, a total of 204 patients admitted to the hospital because of unstable angina, had a typical ECG pattern (1). Thirteen of them had a myocardial infarction just before cardiac catheterization. Data were incomplete in 11 patients. The remaining 180 patients underwent coronary and left ventricular angiography within a mean of 3.3 days after admission. They represent $14 \%$ (180 of 1260$)$ of patients hospitalized during that period with a diagnosis of unstable angina.

\section{Diagnosis of unstable angina:}

Unstable angina was defined as angina of recent onset, sudden worsening of preexisting stable angina or angina after a pain free period (at least 3 months) after a non-anterior myocardial infarction. Chest pain had to have started within 6 weeks before admission. Severity of complaints was classified according to the New York Heart Association (NYHA) Functional Class III or IV. The last episode of chest pain should have taken place within five days before the patient entered the study and could have lasted for a long period of time (more than 20 minutes).

\section{Other inclusion and exclusion criteria}

All patients were less than 76 years of age. If pain was present at the time of admission, it had to respond to sublingual or intravenous nitroglycerin. Patients were excluded if 
they had severe pump failure (New York Heart Association Class III of IV), cardiomyopathy, or previous cardiac surgery or coronary angioplasty; also exchded were those with a pacemaker or anemia.

\section{Electrocardiographic features}

In all patients 12-lead ECGs were routinely obtained twice daily. Additional ECGs were obtained during and after new episodes of chest pain.

All patients had at the time of entry into the study and outside an episode of chest pain ST segment and $T$ wave abnormalities in leads $V_{2}$ and $V_{3}$ (see figure 1).

The abnormalities in leads $V_{2}$ and $V_{3}$ consisted of an isoelectric or minimally elevated $(<1 \mathrm{~mm})$ take-off of the ST segment followed by a concave or straight ST segment and a symmetrically inverted $\mathrm{T}$ wave. One hundred and twenty-one patients also had these changes in lead $V_{1}$.

One hundred thirty-six patients also had ST-T segment abnormalities in lead $V_{4}$, and sometimes in $\mathrm{V}_{5}$ or $\mathrm{V}_{6}$ characterized by a take-off of the ST segment below the isoelectric line followed by a convex ST segment passing into a symmetrically inverted $\mathrm{T}$ wave (fig 1B).

Excluded were patients with $Q$ waves or QS complexes in leads $V_{2}$ to $V_{4}$, patients with a left or right bundle branch block pattern, left or right ventricular hypertrophy and patients with a loss of initial $R$ wave voltage in leads $V_{1}$ to $V_{3}$.

\section{Enzyme measurements}

Serial enzyme values for creatine kinase (CK), serum glutamic oxaloacetic transaminase (SGOT) and serum lactic dehydrogenase (SLDH) were measured in all patients
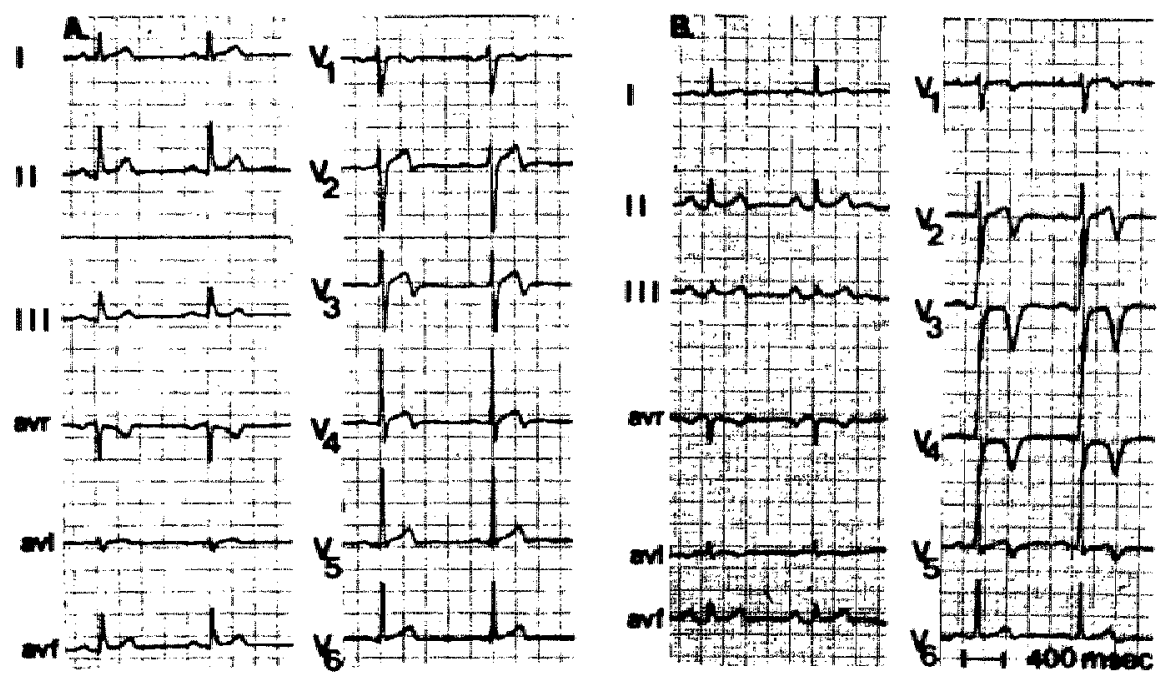

FIGURE 1. Examples of ECG patterns found in precordial leads of paticnts. reported. A, Pattern found in 44 patients; B, Pattern found in 136 patients. (See text for details). 
every 8 hours for 3 consecutive days after admission and were repeated after a new attack of chest pain during hospitalization. The peak values had to be less than twice the upper limit of the normal values $(220,40,400 \mathrm{U} / \mathrm{L}$ respectively) if the patient was to be included in the study.

\section{Cardiac catheterization}

The investigation was performed 3 hours to 10 days (mean 3.3 days) after admission, or 12 hours to 14 days (mean 4.6 days) after the last attack of chest pain.

Coronary angiography was performed by the Judkins technique with multiple projections. The severity of the stenosis was graded subjectively. In 61 of 147 patients with a non-occluded ischemia-related artery, grading was also done quantitatively by means of the previously validated and described computer-based Cardiovascular Angiography Analysis System (CAAS) with high resolution digital subtraction images (4).

Collateral filling of the $\mathrm{LAD}$ was considered to be present if there was visualization of the distal portion of the LAD different from anterograde flow, after injection of the contrast medium either into the right or the circumflex coronary artery or by bridging collaterals from the proximal to the distal segment of the $\mathbb{L A D}$.

Diminished flow was considered to be present if there was anterogradely no distal filling within 3 cardiac cycles.

Abnormalities in left ventricular wall motion were assessed from the 30 -degree right anterior oblique (RAO) and the 60- degree left anterior oblique (LAO) view by means of the modified method of Ingels et al (5). The left ventricular silhouette was divided into anterobasal, anterolateral, apical, diafragmatic, posterobasal and anteroseptal, posterolateral segment respectively. Systolic left ventricular wall motion was graded as normal, hypokinetic, akinetic or dyskinetic.

Diastolic motion of the anterior wall segments was considered to be abnormal if a biphasic or triphasic relaxation pattern and a prolonged relaxation time were present. The films were examined by at least two experienced angiographers.

\section{Treatment regimen}

Medical management consisted of a beta-adrenergic-blocking agent (metoprolol), a nitrate (isosorbide dinitrate). A calcium channel blocker (nifedipine) was given when indicated.

Since 1984 antiplatelet drugs (aspirin, dipyridamole) have been added to this treatment regimen.

\section{Follow-up}

Follow up ended 1.5 years after the last patient was admitted to the study.

Incidence of angina pectoris, myocardial infarction, death, coronary artery bypass surgery (CABG) and coronary angioplasty (PTCA) was recorded after 1 year and at the end of the follow-up period. The mean duration of follow-up was 4.2 years for the survivors. 


\section{OBSERVATIONS}

\section{Clinical characteristics}

As shown in table 1 the mean age of the 180 patients was 55 years. The majority were men. Almost half of the patients had previously had angina pectoris. In $73 \%$ of patients the severity of angina was considered as Class IV (attacks of angina at rest). In this group of patients the last attack of pain had occurred 1.2 days (mean) before admission and had lasted an average of 39 minutes. The mean duration of unstable angina was 4.9 days. In patients with angina during slight exercise (Class III) these values were 1.8 days, 11 minutes and 11.4 days, respectively.

\section{Findings at coronary angiography}

As shown in table 2 all patients had abnormalities in the LAD. The site of most severe occlusion or narrowing was proximal to the first septal perforator in $29 \%$ of patients $(\mathrm{n}=53)$ and between the first and second septal branch in $54 \%(\mathrm{n}=97)$. The lesion in the LAD was the only abnormality (single-vessel disease) in 75 patients. Sixty-six patients had additional disease in one vessel and 39 patients had significant narrowing in both remaining coronary arteries. Severe mainstem disease as the "culprit" lesion was not found in these patients. More than half of the patients had calcifications in the LAD.

The LAD was completely obstructed in 33 patients. In the remaining 147 patients the degree of narrowing varied from 50 to $99 \%$, with a mean of $85 \%$ according to subjective analysis and $79 \%$ according to quantitative analysis (CAAS).

Diminished anterogradely flow over the stenosis in the LAD was observed in 25 patients; in 18 of 77 vessels with near-total occlusion (90-99\%), in 5 of 46 arteries with diameter narrowing of $80-90 \%$, and in 2 vessels with diameter narrowing of $50-80 \%$.

TABLE 1. Clinical characteristics of patients at the time of entry into the study.

\begin{tabular}{lrl}
\hline No of patients & 180 & \\
Age in years, mean $\pm \mathrm{SD}$ & 55 & \pm 9 \\
Men & 124 & \\
Previous angina pectoris & 86 & \\
Previous myocardial infarction & 20 & \\
Severity of AP at entry - - Class III & 49 & \\
$\quad$ - Class IV & 131 & \\
Duration of unstable angina pectoris at & & \\
entry in days, mean \pm SD & 6.6 & \pm 9.0 \\
$\quad$ median & 3.0 & \\
Time interval between last attack of chest & & \\
pain and admission in days, mean \pm SD & 1.3 & \pm 1.3 \\
CK - 1x to $2 x$ upper limit. of normal & 21 & \\
$\quad$ - normal & 157 &
\end{tabular}

$\mathrm{AP}=$ angina pectoris; $\mathrm{CK}=$ creatine kinase. 
TABLE 2. Coronary angiographic characteristics of patients.

\begin{tabular}{|c|c|c|c|}
\hline No of patilients & & 180 & \\
\hline No of diseased vessels - & 1 & 75 & \\
\hline & 2 & 66 & \\
\hline & 3 & 39 & \\
\hline Occluded LAD & & 33 & \\
\hline Narrowed LAD & & & \\
\hline diameter narrowing & subjectivaly $(n=14$ & & \\
\hline & in $\%$, mean $\pm S D$ & 85 & \pm 10 \\
\hline area of stenosis - & $\operatorname{CAAS}(n=61)$ & & \\
\hline & in $\%$ mean $\mathrm{AD}$ & 79 & \pm 16 \\
\hline Diminished anterogradle & Wow over LAD & 25 & \\
\hline Calcilication of LAD & & 97 & \\
\hline Collaterals to LAD & & 75 & \\
\hline
\end{tabular}

$\mathrm{CAAS}=$ cardiovascular angiography analysis system; LAD = left anterior descending artery.

Collateral circulation was present in all 33 totally obstructed arteries, in 35 of 77 vessels with near-total occlusion (90-99\%) and in 7 of 46 arteries with diameter narrowing of $80-90 \%$.

We did not find any significant relation between results of coronary angiography and duration of unstable angina pectoris, although no occluded vessels and a low incidence of collaterals (4/14) were found in 14 patients with a duration of unstable angina of only one day. Comparison with severity of anginal complaints, Class IV as compared to Class III, yielded a reduced incidence of collaterals ( 49 of 131 ws 26 of 49 patients, CHI-2 test: $p=0.08$ ) and a lower incidence of totally occluded arteries ( 20 of 131 vs 13 of 49 patients, CHI-2 test: NS) in Class IV angina.

\section{Findings at left ventricular angiography}

Systolic left ventricular wall motion abnormalities related to the diseased LAD were present in 137 patients. The abnormal systolic motion was hypo- or akinesis in 130 patients. In the remaining 7 patients regional dyskinesis was observed. Many patients had systolic wall motion abnormalities in more than one segment. The anteroseptal region was most commonly involved $(n=97)$ as compared to the apical $(n=75)$, anterolateral $(n=66)$ and anterobasal $(n=28)$ segments.

The interval between the last attack of chest pain and angiography was an average of $4.1( \pm 2.5)$ days for the 137 patients with abnormal systolic wall motion and $6.4( \pm$ $3.3)$ days for the remaining 43 patients with normal systolic left ventricular function (Student's unpaired 'T-test, $\mathrm{p}<0.001$ ).

Abnormal diastolic left ventricular wall motion was observed in 153 patients: 129 of 137 with abnormal systolic wall motion and 24 of 43 with normal systolic wall motion.

No serious complications occurred during or after cardiac catheterization in this group of patients with unstable angina. One patient had non-sustained ventricular tachycardia during coronary angiography. 


\section{Electrocardiographic findings}

The ellectrocardiographic findings described in the Methodology section were present at the time of admission to the hospital in 108 patients. In 72 patients the ECG abnormalities develloped later: within 24 hours after admission in 56 patients, within 2 days in 10 , within 3 days in 5 and within 5 days in one.

During an attack of chest pain at the time of or after admission to the hospital, the clescribed ST-T segment abnormalities in the precordial leads normalized or the patient had ST segment elevation.

When we studied correlations between clinical and angiographic findings in patients with the typical ECG pattern "at the time of" admission or "after" admission, we found that the mean duration of unstable angina in the former group was insignificantly longer $(\mathrm{n}=108$, mean \pm SD $7.6 \pm 8.1$ vs $\mathrm{n}=72$, mean \pm SD $5.3 \pm 557.1$ days $)$. Furthermore a higher incidence of collaterals (52/108 vs $23 / 72$, CHI 2 test: $p<0.05$ ) was present in patients with ST-T segment changes on admission.

We also correlated the presence or absence of abnormal ST-T the presence or absence of abnormal systolic left ventricular wall motion. If the ECG was still abnormal there was a greater chance of abnormal systolic left ventricular wall motion as when the ECG had normalized ( 131 of 159 vs 6 of 21 patients, CHI-2 test: $p<0.001$ ).

The long-term duration of the ST-T segment abnormalities could be established from visits to the outpatient clinic in 152 of 180 cases (table 3). As shown normalization of the ST-T segments occurred in the majority of patients. In 28 patients no ECGs were reviewed because of death or the development of a myocardial infarction or because the ECG was not available.

\section{Enzyme measurements}

Twenty-one patients had a small increase in enzyme values. In 10 patients only the creatine kinase level was elevated (mean: $294 \mathrm{U} / \mathrm{L}$ ). In 11 patients there was also release of SGOT, which was always less than twice the upper limit of normal (mean 53 $\mathrm{U} / \mathrm{L})$.

Of these 21 patients 19 had Class IV angina, 17 had angina of recent onset and eight had total occlusion of the ischemia-related LAD. These incidences are higher in comparison to the total study population. However, the incidence of collaterals at the time of catheterization ( 9 of 21) was not different.

TABLE 3. Electrocaudiographic findings in the outpatient clinic.

\begin{tabular}{lrrrr}
\hline Treatment Group & & I & II & \multicolumn{1}{c}{ III } \\
\hline ST-T segment-normal at first visit & $(\%)$ & $12 / 26(46)$ & $48 / 101(48)$ & $6 / 25(24)$ \\
ST-T segment-normalized $<6$ months & $(\%)$ & $21 / 26(81)$ & $95 / 101(94)$ & $21 / 25(84)$ \\
ST-T segment-remained abnormal & $(\%)$ & $5 / 26(19)$ & $6 / 101(6)$ & $4 / 25(16)$ \\
\hline
\end{tabular}

$\mathrm{I}=$ medical therapy (assigned and ultimate treatment); II = early revascularization;

III = late revascularization. 


\section{Clinical course}

At the time of admission to the hospital all patients were treated with medical therapy (nitrates, beta-adrenergic blocking agents and/or calcium channel blockers).

In view of our earlier experience in 26 patients (1) where we found a high incidence of anterior wall myocardial infarction during hospitalization and large areas at risk at the time of cardiac catheterization, most of our patients had early revascularization.

In the present study nine patients had a myocardial infarction 6 days (mean) after admission to the hospital and before scheduled revascularization. The mean peak SGOT value was $320 \mathrm{U} / \mathrm{L}$. During hospitalization 2 of the patients with infarctions died, both because of pumpfailure.

As shown in figure 2,115 patients underwent (within a mean of 12 days after hospital admission) bypass surgery ( 103 patients) or angioplasty (12 patients), whereas 56 patients were treated medically.

During early bypass surgery 6 patients had myocardial infarction. During hospitalization 3 early revascularized patients died: two of the 6 infarcted patients because of pump failure and 1 of the 109 non-infarcted patients because of sepsis.

Of the 56 initially medically treated patients, 26 remained unstable or became refractory to drug therapy and ultimately underwent a revascularization procedure (a mean of 8 months and 15 days after the initial admission).

\begin{tabular}{ccc} 
EARLY & MEDICAL & LATE \\
AEVASCULARIZATION & THERAPY & REVASCULARIZATION \\
\hline
\end{tabular}

NO PTS

AMI BEFORE

revasculatization

124

56

REVASCULLARIZED

AMI DUFING

REVASCULAAIZATION

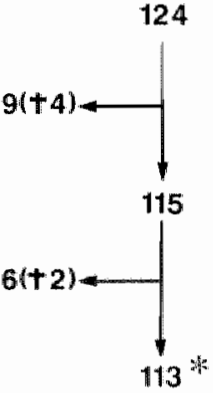

AMI DURING

FOLLOW-UP

AT END

FOLLOW-UP
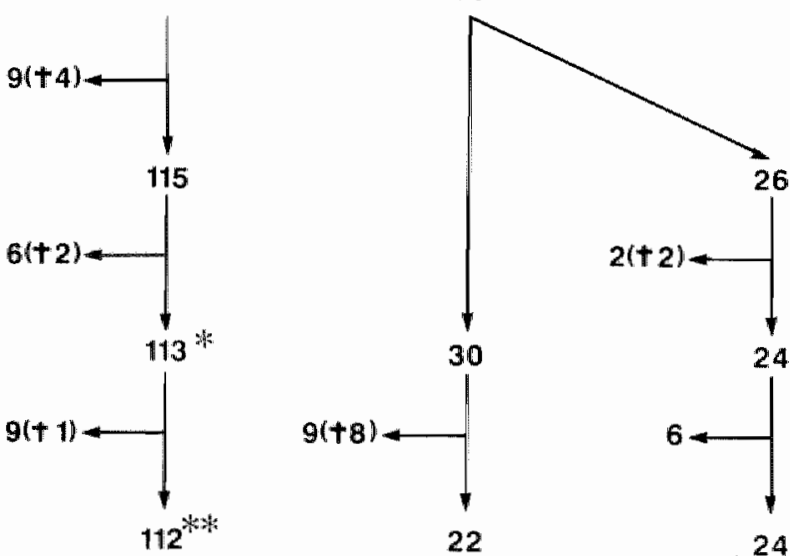

FIGURE 2. Flow chart showing modes of treatment, and incidence of acute myocardial infarction (AMI) and cardiac death during follow-up.

AMI $=$ acute myocardial infarction; $\dagger=$ number of patients with cardiac death; ${ }^{*}=$ one patient died of sepsis: $^{* *}$ = five patients died of noncardiac-related causes. 


\section{Treatment}

Twenty-five surgically treated patients received only one bypass graft, 36 received two, 29 received three, 20 received four, 16 received five, 2 received six and 1 patient received seven (mean: 2.8 ).

In only 6 of 99 operation reports was a scar of myocardial infarction mentioned as being present. The overall operative mortality rate (early and late revascularization surgery) was 5 of 129 patients; four patients died of pump failure from myocardial injury that developed during surgery (two of these patients also received a valve prosthesis); one patient died of sepsis.

During follow-up 98 of 141 revascularized patients became asymptomatic. Five patients required either reoperation $(n=3)$ or a second angioplasty $(n=2)$.

Thirty patients did not undergo a revascularization procedure for one or more reasons such as control by medication ( $(n=21)$, less than $65 \%$ LAD stenosis $(n=4)$, extensive collateral circulation to $L A D(n=13)$, or location of the ischemia-related lesion in the first diagonal branch $(n=2)$. Other reasons included: inoperability $(n=3)$ and refusal $(\mathrm{n}=2)$.

Only 8 of the 30 nonrevascularized patients continued to have no complaints, including all 4 patients with non-severely narrowed vessels and 4 of 12 patients with an occluded ischemia-related LAD at the time of the initial angiography. Eight of the 30 patients died ( 2 with extensive collateral circulation, 2 considered to be inoperable, and one who refused intervention).

\section{Myocardial Infarction and Cardiac Death}

According to figure 2 twenty-four patients had a myocardial infarction during followup. For the sake of simplicity we incorporated in this group of myocardial infarction 6 cases who had sudden death ( 1 of the early revascularization and 5 of the medical therapy group).

In 35 patients who had a proven myocardial infarction we observed the following: 1) According to the baseline angiogram the mean number of diseased coronary arteries was higher compared to the remaining patients in the total study population ( 2.1 of 35 vs 1.7 of 145 patients, CHI-2 test: $p<0.01$ ).

2) Patients who had the acute myocardial infarction in the hospital (9 before and 6 during early revascularization) had no occluded ischemia-related left anterior descending coronary arteries (CHI-2 test: NS) and less collaterals compared to the non-infarcted patients of the total series ( 2 of 15 vs 73 of 165 patients, CHI-2 test: $p<0.05$ ). 3) In both the "medically" treated and the revascularization-related groups with myocardial infarction, the infarct was always located in the anterior wall. In the two series of postintervention myocardial infarction this was the case in only $43 \%$.

\section{COMMENTS}

In view of the importance of the LAD in supplying blood to the left ventricular myocardium (6), recognition of patients with unstable angina and severe narrowing of the LAD is of obvious importance. 
We became aware of an ECG pattern suggestive of a critical lesion in the proximal LAD when we retrospectively studied the electrocardiographic findings in patients admitted with unstable angina. Our study reported in 1982 was also composed of patients studied prospectively. Our impression at that time was that medical treatment of patients with unstable angina showing the described ECG pattern was followed by a high incidence of extensive anterior wall myocardial infarction (1).

This experience and the angiographic finding of extensive segmental myocardial dysfunction prompted us to treat this subgroup of patients with unstable angina - in principle - more aggressively by way of coronary artery bypass grafting or angioplasty.

\section{Location and severity of LAD disease and incidence of collateral circulation.}

Patients with unstable angina have a higher incidence of left main and of proximal left anterior descending coronary artery disease compared to patients with stable angina pectoris (7). When patients with unstable angina have the typical ECG pattern decribed, $83 \%$ will have their "culprit" lesion proximall to the second septal perforator. In our study 106 patients had a complete $(n=33)$ or almost totally occluded $(n=73)$ ischemia-related vessel, which is in agreement with the study of Plotnick et al (8).

In the stenotic vessels the mean degree of narrowing was $85 \%$ with subjective analysis and $79 \%$ with quantitative analysis (CAAS). According to McMahon (9) the subjectively graded coronary artery severity is comparable to the quantitatively assessed area of stenosis. The percentage of stenosis determined by videodensitometry correlates well with the percentage of reduction in cross-sectional area as measured by histologic planimetry in postmortem hearts $(r=0.97)(10)$.

Our patients were characterized by absence of the development of $Q$ wave infarction in the anterior wall. It is well known that the presence of collaterals affects the extent and severity of myocardial injury $(8,11,12)$. Collateral vessels were visualized in this study in all (of 33 ) totally occluded coronary arteries, in 35 of 77 vessels with neartotal occlusion (90-99\%) and in 7 of 46 segments with $80-90 \%$ diameter narrowing.

\section{Angiographic Findings Related to Clinical Findings}

An occluded LAD and collaterals were more often seen in Class III angina pectoris than in Class IV, although these differences were not statistically significant.

The mean duration of the interval between the last attack of chest pain and angiography was longer in the former compared to the latter group (5.9 vs 4.2 days) as was the mean duration of unstable angina at the time of admission (11.4 vs 4.9 days). It is possible that Class III unstable angina is the result of a slowly diminishing flow over a gradually increasing vessel diameter narrowing and a moderate flow over collaterals, whereas Class IV unstable angina is caused by a "sudden" reduction of flow in a severely stenosed artery and sluggish flow by way of collaterals (if present).

It is of interest that all 15 patients, who subsequently had an anterior myocardial infarction had no occluded LAD and of the 33 patients with an occluded vessel at the time of initial angiogram had an acute myocardial injury during hospitalization. Aggressive therapy therefore seems to be more important in unstable patients with proximal LAD stenosis and no collaterals compared to patients with an occluded LAD and collateral circulation. 


\section{Left Ventricular Wall! Motion}

Whereas only 21 patients had a slight increase in enzyme levels, abnormal systolic wall motion was found in 137 patients. These wall motion abnormalities were most likely caused by hibernating or sturned myocardium (13-16). The fact that in only 6 of 99 operation reports an anterior wall myocardial scar was mentioned to be present is sug. gestive of that mechanism. Although not quantified the alterations described in diastolic wall motion can be another illustration of stunning (17). Recent evidence suggests that abnormalities in diastolic function persist beyond the recovery of normal systolic function in patients rendered ischemic for brief periods during percutaneous transluminal coronary angioplasty (18).

\section{Electrocardiographic Observations}

During the phase of terminal T wave negativity in the left precordial leads most patients had transient QT prolongation. These changes were partly produced by incorporation of a negative $U$ wave in the terminal part of the negative $T$ wave.

The group with ST-T segment abnormality at the time of admission to the hospital, had a history of unstable angina which was 2.3 days longer, whereas the severity of coronary disease was the same compared to the population in which the abnormality developed later. This finding suggests that duration of myocardial ischemia was responsible for development of the ST-T segment changes.

Ninety percent of patients regained a normal ST-T segment over time. The recovery time was longest in patients who continued to have complaints or became refractory to medical therapy, also suggesting persistence of myocardial ischemia.

However, more collaterals were visualized at the initial angiography in the group with abnormal ECGs on admission compared to those in whom the changes developed during hospitalization ( 52 of 108 vs 23 of 72 patients). This suggests that reperfusion by collaterals may have accelerated desintegration of injured cells in the former group (19).

\section{Myocardial Infarction and Death}

During the study period 204 patients initially had unstable angina and a typical ECG pattern. Eleven patients had incomplete data and 13 patients had an anterior wall myocardial infarction before angiography was performed. Fifteen of 180 patients who entered the study had an extensive anterior wall infarction soon after angiography. Therefore 28 of $204(13,7 \%)$ patients initially seen with the syndrome had extensive myocardial damage during hospitalization. As a consequence of this injury 9 patients died shortly after admission ( 4 of the earlier mentioned preangiography infarcted 13 patients and 5 of the 15 postangiography infarcted patients). The incidence of myocardial infarction in this high-risk group was low in comparison to data in the literature $(20,21)$. We believe that this low incidence was obtained by our approach, which was to treat these patients aggressively on an urgent basis. The death - acute MI ratio was high, indicating the short-term "risk" in this patient population.

Following discharge after the initial hospitalization, at the end of the follow-up period, another 26 patients had acute MI ( 2 during late revascularization) and 11 patients died of cardiac-related causes. Most of the cardiac deaths occurred in suggesting bet- 
ter outcome with revascularization. However, in the absence of randomization to medical or revascularization therapy, such a conclusion should be made with caution.

\section{Revascularization}

Data have been published showing that disease of the proximal LAD is associated with a high risk (22) and that those patients have a better chance of survival when treated with coronary bypass surgery (23). It is suggested that ischemia (in our study illustrated by the large areas of jeopardized left ventricular myocardium during angiography) is likely to be responsible for cardiac death and morbidity (24), and that revascularization is far more effective in relieving ischemia than pharmacologic therapy (24-26).

Coronary bypass surgery was ultimately performed in the present study in 129 patients. Five patients died. If we exclude the 3 patients with an additional artificial value the operative mortality rate (1.6\%) is as low as described by Rahimtoola et al (27) in 1282 patients with unstable angina, namely $1.8 \%$. The perioperative myocardial infarction rate in our study of unstable angina was 8 of 129 patients (6.2\%).

\section{Limitations of the Study}

The present study does not allow a comparison of efficacy of medical versus revascularization therapy because no randomization procedure was followed in either treatment group.

Also the study was done at a time when coronary angioplasty was not performed as often as at the present time and thrombolytic therapy was not used in unstable angina. Now early revascularization by PTCA plays an important role in this subgroup of patients with unstable angina $(28,29)$. However, although a high incidence of thrombosis has recently been shown in unstable angina $(30,31)$ the value of thrombolytic therapy in these patients has not yet been established.

\section{Practical implications}

Risk stratification and correct treatment of patients admitted because of acute coronary syndromes is one of the most important challenges in modern cardiology.

This study stresses the importance of being aware that a distinct electrocardiographic pattern, present on admission or developing shortly thereafter, allows recognition of patients with unstable angina and a critical lesion proximal in the LAD as having a poor prognosis.

We found that the risk of myocardial infarction was lowest in patients with an occluded LAD and collateral circulation and highest in those with a high degree of stenosis without collaterals. Especially the latter group of patients should be revascularized on an urgent basis.

We believe that early catheterization is indicated in these patients to identify those requiring early revascularization.

\section{Acknowledgment}

The authors express their gratitude to Dr Frank JGM Kubben for his contribution to this study. 


\section{REFERENCES}

1. de Zwaan C, Bär FWHM, Wellens HJJ:

Characteristic electrocardiographic pattern indicating a critical stenosis high in left anterior descending coronary artery in patients admitted because of impending myocardial infarction. Am.Heart J. 1982; 103: 730-735.

2. Haines DE, Raabe DS, Gundel WD, Wackers FJTh:

Anatomic and prognostic significance of new $T$-Wave inversion in unstable angina. Am. J. Cardiol. 1983; 52: 14-18.

3. Boden WE, Bough EW, Benham J, Shulman RS:

Unstablle angina with episodic ST segment elevation and minimal creatine kinase release culminating in extensive recurrent infarction. I. Am. Coll. Cardiol. 1983; 2: 11-20.

4. Reiber JHC, Serruys PW, Kooyman CJ:

Assessment of short-, medium-, and long-term variations in arterial dimensions from computer-assisted quantitation of coronary cineangiogram. Circulation 1985; $71: 280-288$.

5. Ingels NBJr, Daughters GT, Stinson EB, Alderman EL:

Evaluation of methods for quantitating left ventricular segmental wall motion in man using myocardial markers as a standard. Circulation 1980; 61: 966-972.

6. Edwards WD, Tajk AJ, Seward JB:

Standardized nomenclature and anatomic basis for regional tomographic analysis of the heart. Mayo Clin. Proc. 1981; 56: 479-497.

7. Plotnick GD, Greene HL, Carliner NH, Becker LC, Fisher ML:

Clinical indicators of left main coronary artery disease in unstable angina. Ann. Intern. Med. 1979; 91: 149-153.

8. Plotnick GD, Fisher ML, Lerner B, Carliner NH, Peters RW, Becker LC:

Collateral circulation in patients with unstable angina. Chest 1982; 82: 719-725.

9. McMahon MM, Brown BG, Cukingnan R, Rolett EL, Bolson E, Frimer M, Dodge HT:

Quantitative coronary angiography: measurement of the "critical" stenosis in patients with unstable angina and single vessel disease without collaterals. Circulation $1979 ; 60$ : 106-113.

10. Nichols AB, Gabrieli CFO, Fenoglio JJ, Esser PD:

Quantification of relative coronary arterial stenosis by cinevideo densitometric analysis of coronary arteriograms. Circulation 1984; 69:512-522. 
11. Gorlin $R$, Fuster $V$, Ambrose JA:

Anatomic physiologic links between acute coronary syndromes. Circulation 1986; 74: 6-9.

12. Epstein $\mathrm{SE}$ :

Influence of stenosis severity on coronary collateral development and importance of collaterals in maintaining left ventricular function during acute coronary occlusion. Am. J. Cardiol. 1988; 61:866-868.

13. Kloner RA:

Persistent myocardial abnormalities following brief periods of temporary coronary occlusion not associated with necrosis. Circulation 1980; 62: III 80 (Abstract).

14. Flameng W, Wouters L, Sergeant P, Lewi P, Borgers M, Thone F, Suy R:

Multiwariate analysis of angiographic, histologic and electrocardiographic data in patients with coronary heart disease. Circulation 1984; 70; 7-17.

15. Braunwald E, Rutherford JD:

Reversible Ischemic Left Ventricular Dysfunction: Evidence for the "Hibernating Myocardium". J. Am. Coll. Card. 1986; 8: 1467-1470.

16. Preuss KC, Gross GJ, Brooks HL, Warltier DC:

Time course of recovery of "stunned" myocardium following variable periods of ischemia in conscious and anesthetized dogs. Am. Heart J. 1987; 114:696-703.

17. Przyklenk K, Patel B, Kloner RA:

Diastolic abnormalities of postischemic "stunned" myocardium. Am. J. Cardiol 1987; 60: 1211-1213.

18. Wijns W, Serruys PW, Slager CJ, Grimm J, Krayenbuehl HP, Hugenholtz PG, Hess OM:

Effect of coronary occlusion during percutaneous transluminal angioplasty in humans on left ventricular chamber stiffness and regional diastolic pressure-radus rellations. J. Am. Coll. Cardiol. 1986; 7: 455-463.

19. Jennings RB, Reimer KA:

Factors involved in salvaging ischemic myocardium: Effect of reperfusion of arterial blood. Circulation 1983; 68: I, 25-36.

20. Neill WA, Whorton TPJr, Fluri-Lundeen J, Cohen JS*

Acute coronary insufficiency-coronary occlusion after intermittent ischemia attacks. N. Engl. J. Med. 1980; 302: 1157-1162. 


\section{HINT Research Group:}

Early treatment of unstable angina in the coronary care unit: a randomised, double blind, placebo-controlled comparison of recurrent ischaemia in patients treated with nifedipine or metoprolol or both. Br. Heart J. 1986; 56: 400-413.

22. Ellis S, Alderman E, Cain K, Fisher L, Sanders W, Bourassa M, and the CASS investigators:

Prediction of risk of anterior myocardial infarction by lesion severity and measurement method of stenoses in the left anterior descending coronary distribution: a CASS registry study. JACC 1988; 11, 908-916.

23. Neill WA:

Staccato left anterior descending artery occlusion: a recognizable subset of unstable angina. J. Lab. Clin. Med. 1985; 105: 390-396.

24. Rahimtoola SH:

Coronary bypass surgery for unstable angina. Circulation 1984; 69: 842-848.

25. Rahimtoola SH:

Coronary bypass surgery for chronic angina - 1981: a perspective. Circulation 1982; 65: $225-241$.

26. Mock MB, Fisher LD, Holmes DRJr, Gersh BJ, Schaff HV, Mc Conney M, Rogers WJ, Kaiser GC, Ryan TJ, Meyers WO, Killip III Th, and participants in the CASS: Conparaison of effects of medical and surgical therapy on survival in severe angina pectoris and two-vessel coronary artery disease with and without left ventricular dysfunction: a CASS registry study. Am. J. Cardiol. 1988; 61: 1198-1203.

27. Rahimtoola SH, Nunley D, Grunkemeier G, Tepley J, Lambert L, Starr A:

Ten year survival after coronary bypass surgery for unstable angina. N. Engl. J. Med. $1983 ; 308: 676-681$.

28. de Feyter PJ, Serruys PW, Suryapranata $H$, Beatt $K$, van den Brand M:

Coronary angioplasty early after diagnosis of unstable angina. Am. Heart J. 1987; 114: 48-54.

29. Leeman DE, McCabe CH, Faxon DP, Lorell BH, Kellett MA, McKay RG, Varricchione T, Baim DS:

Use of percutaneous transluminal coronary angioplasty and bypass surgery despite improved medical therapy for unstable angina pectoris. Am. J. Cardiol. 1988; 61: $38 \mathrm{G}-44 \mathrm{G}$. 
30. Gold HK, Johns JA, Leinbach RC, Yasuda T, Grossbard E, Zusman R, Collen D: A Randomized, blinded, placebo-controlled trial of recombinant human tissuetype plasminogen activator in patients with unstable angina pectoris. Circulation 1987; 75: 1192-1199.

31. Gotoh K, Minamino T, Katoh O, Hamano Y, Fukui S, Hori M, Kusuoka H, Mishima $M$, Inoue $M$, Kamada $T$ :

The role of intracoronary thrombus in unstable angina; angiographic assessment and thrombolytic therapy during ongoing anginal attacks. Circulation 1988; $77: 526-$ 534.

32. de Zwaan C, Bär FW, Janssen JHA, de Swart HB, Vermeer F, Wellens HJJ: Effects of thrombolytic therapy in unstable angina: clinical and angiographic results. J. Am. Coll. Cardiol. 1988; 12: 301-309. 


\title{
CHAPTER IV
}

\section{Proximal left anterior descending coronary artery disease: are we able to recognize this "high- risk" lesion}

\author{
Chris de Zwaan MD and Hein JJ Wellens MD.
}

Submitted for publication

\section{Introduction}

The left anterior descending coronary artery (LAD) supplies a large portion of the interventricular septum and the anterior and apical segments of the left ventricle, all together 40 to $55 \%$ of left ventricular myocardial mass (1). The importance of the LAD is reflected in a twice higher mortality rate in non surgically treated patients with single vessel disease in the $L A D$ as compared to right coronary artery disease (2).

Autopsy studies in patients who die of acute myocardial infarction (AMI) have shown an overall incidence of stenosis in the proximal LAD of $23 \%$ However, an acute thrombotic lesion in the proximal LAD was responsible for $61 \%$ of fatal myocardial infarctions, which is therefore approximately 3 times higher than anticipated (3).

Importance of $L A D$ disease is related to its location. Differentiation has to be made in a lesion located proximal and distal to the first septal perforator. The 5 year mortality rate in isolated LAD disease is much higher in the former than in the latter location (5 years combined medical and surgical mortality rate $11 \%$ vs $2 \%$ respectively) (4). The same differences are found in medically treated patients with combined stenoses of a proximal or a non proximal LAD and of a proximal circumflex coronary artery ( 5 year survival $54 \%$ vs $70 \%)(5)$.

There are also significant differences in mortality rate in survivors of acute myocardial infarction comparing proximal to non proximal left coronary artery disease. At 30 months this is $27 \%$ in patients with proximal left CAD and only $4 \%$ in those with non proximal left CAD (6).

In survivors of myocardial infarction it has also been shown that at 3 years, the mortality rate from cardiac causes and the incidence of recurrent myocardial infarction in patients with LAD disease is similar to that of the total group of patients with multivessel disease, including LAD disease (table 1). At 3 years the presence of LAD disease accounts for $80 \%$ of all deaths (7).

\section{Identification of the high risk patient:}

The important question arises if it is possible to identify patients with such a higlh-risk lesion. Preferably before occlusion leads to anterior wall infarction, there are electrocardiographic patterns which are very suggestive for a critical narrowing in the proximal LAD. Patients with angina pectoris during exercise and patients with an impend- 
TABLE 1: Survivors of Acute Myocardial Infarction Not Treated with Coronary Bypass Surgery (De Feyter el al $(7)$ ).

\begin{tabular}{|c|c|c|c|}
\hline \multirow{2}{*}{$\begin{array}{l}\text { Eutent of } \\
\text { disease }\end{array}$} & \multirow{2}{*}{$\begin{array}{c}\text { No. ol } \\
\text { patients. }\end{array}$} & \multicolumn{2}{|c|}{ Cumulative Incidence at 3 years } \\
\hline & & Cardiac deathsi & Recurrent MI \\
\hline 1.-wessel * & 81 & $9.7 \%$ & $16.1 \%$ \\
\hline 2-Wessive: & 72 & $8.1 \%$ & $10.8 \%$ \\
\hline 3*Wessel: & 26 & $35.7 \%$ & $21.4 \%$ \\
\hline Multiwessel oligeasot & 98 & $15.7 \%$ & $13.7 \%$ \\
\hline LAD discase only & 125 & $14.5 \%$ & $12.9 \%$ \\
\hline
\end{tabular}

* Including $\mathrm{LAD}$ disease; $\mathrm{LAD}=$ left anterior descending coronary artery; $\mathrm{MI}=$ myocardial infarction.

A

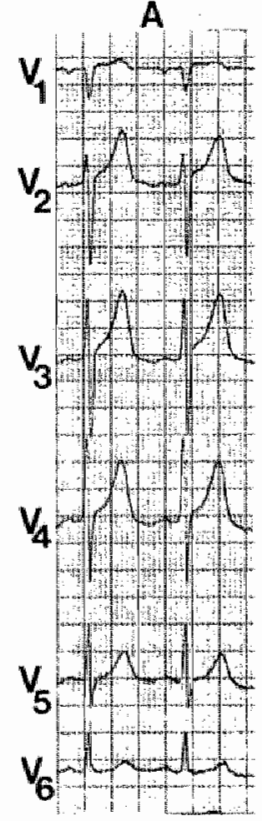

B
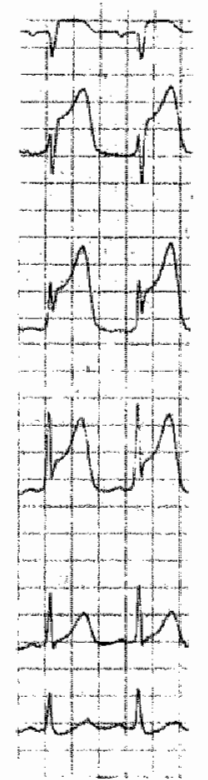

C

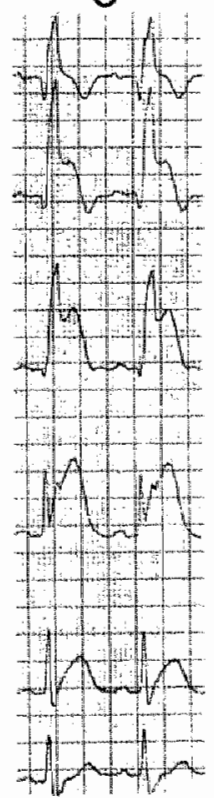

D

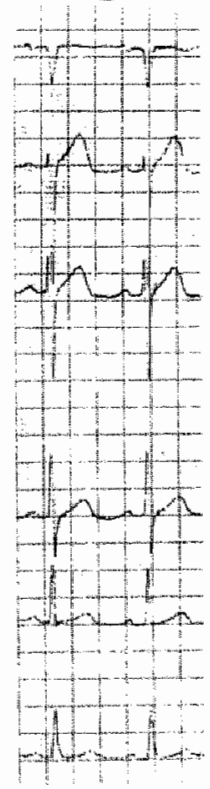

$E$

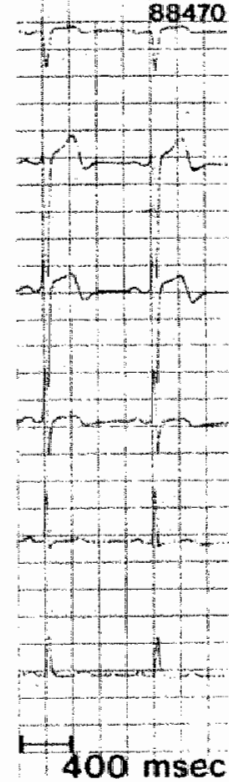

FIGURE 1: Recording of ECG before (A), during $(\mathrm{B}, \mathrm{C})$ and after (D,E) an attack of angina pectoris. As shown a pattern of transient $Q$ wave and complete right bundle branch block (C) was present during pain. 
A

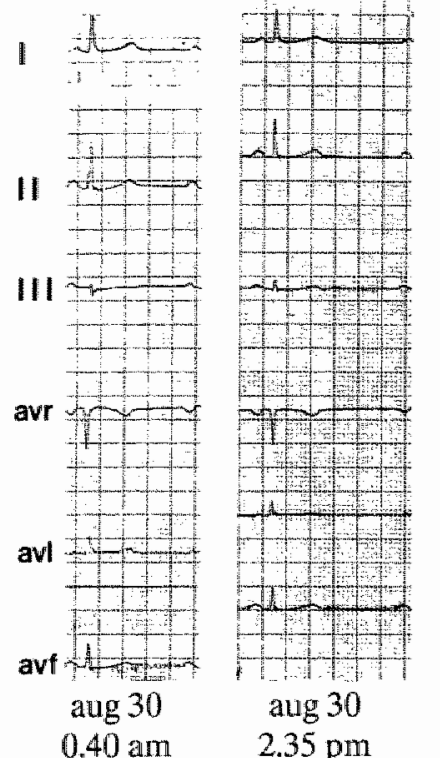

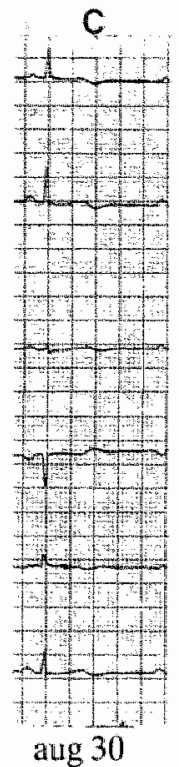

$6.15 \mathrm{pm}$
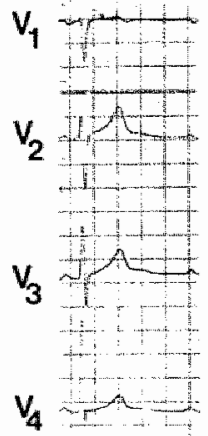

$V_{5}+\log _{1}$

$V_{6}$
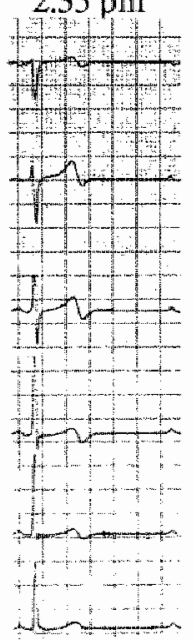

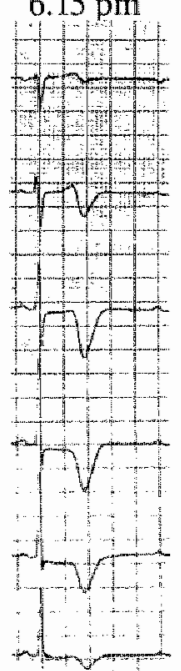

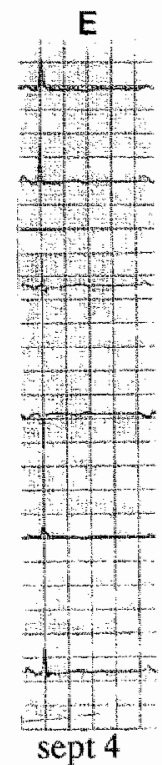

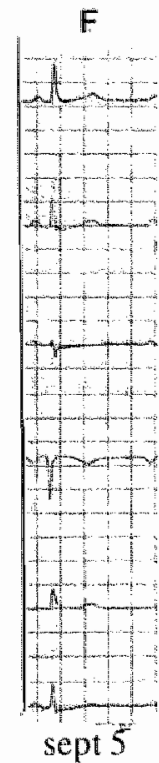

$9.40 \mathrm{pm}$

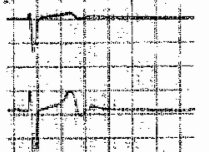

$8.10 \mathrm{am}$

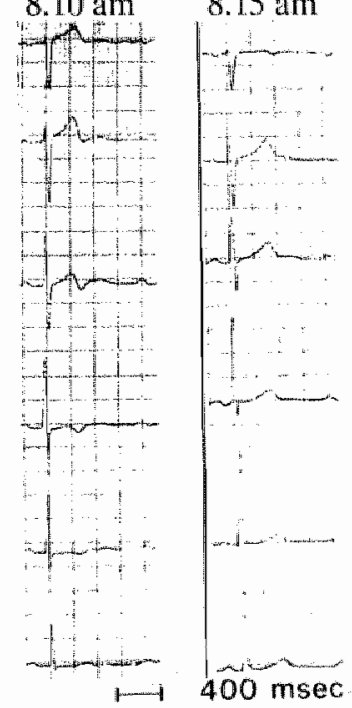

FIGURE 2: Panels A to F show the electrocardiographic changes in the ST-T segment of the precordial leads in a patient admitted because of unstable angina having a critical narrowing in the proximal $L A D$. Panel A was recorded on admission while the patient was without complajnts. Panels B to $\mathrm{F}$ were made respectively 14 and 17.5 hours and 1,4 and 5 days after admission during a symptom free follow-up period. During hospitalization the CK walues remained normal. In panels B to D the characterist ic ST-T $\mathrm{T}$ segment changes are present. As shown in panel $B$ a concave ST segment is followed by an inverted $T$ wave. Panel $C$ illustrates the development of deep terminal $T$ wave negativity. Panels $D$ to $F$ show a return of these ST-T segment changes to normal. 
ing myocardial infarction at rest seldomly show during pain a pattern of left anterior hemiblock (8) or a complete right bundle branch block (figure 1). From our experience the incidence was 3 and 2 of 180 patients respectively.

Much more common is another typical electrocardiographic pattern pointing to a severe stenosis in the proximal LAD and seen in patients admitted to hospital because of an impending myocardial infarction (9-11). In a recent study (12) we found this electrocardiographic pattern consisting of abnormalities in the ST-T segment in the precordial leads (figure 2) in 204 of 1260 patients (16\%) admitted to hospital because of unstable angina. These ECG changes, which are accompanied by wall motion abnormalities, are suggestive for a stunned or hibernating left ventricular anterior and septal wall consequent to a severe reduction in blood flow in the LAD in the vicinity of the first septal branch. Restoration of blood flow by anti-ischemic drugs, PTCA or coronary bypass surgery led within days to weeks to normalization of the ellectrocardiogram and wall] motion (13).

Unfortunately the ECG pattern shown in figure 2 does not allow to predict accurately which patient with unstable angina is at highest risk to develop extensive anterior wall infarction. In the future non-invasive assessment like digital two-dimensional echocardiography (14) and transesophageal color Doppler technique (15) might be used to estimate the presency and severity of LAD stenosis and its consequences for coronary flow. Up to now coronary angiography is required. In our study (12) patients with a stenosis of more than $90 \%$ without collaterals were at highest risk. No infarction occurred early during follow-up in patients having an occluded LAD and collateral circulation.

In the CASS study (16) medically treated patients having a 90 to $98 \%$ narrowing in the LAD had a $15 \%$ three years risk of non fatal anterior wall myocardial infarction as compared to a 7\% risk of those having a totally occluded LAD. In the CASS study multiple maximal percent stenoses of $>50 \%$ severity measured by computer techniques

TABLE 2: The European prospective Randomized Study of Coronary Bypass Surgery in Stable Angina Pectoris and multiwessel disease $(17,18)$.

\begin{tabular}{|c|c|c|}
\hline & $\begin{array}{c}\text { Prox. LAD } \\
\text { discase absent }\end{array}$ & $\begin{array}{c}\text { Prox. LAD } \\
\text { disease present }\end{array}$ \\
\hline \multicolumn{3}{|l|}{ Mortallity at 5 years } \\
\hline Medically treated & $8 \%$ & $18 \%$ \\
\hline Surgically lreated & $7 \%$ & $7 \%$ \\
\hline p walue & NS & 0.0004 \\
\hline \multicolumn{3}{|c|}{ Mortallity int 10 years } \\
\hline Medically treated & $17 \%$ & $35 \%$ \\
\hline Surgically treated & $19 \%$ & $24 \%$ \\
\hline p value & NS & 0.007 \\
\hline
\end{tabular}

\footnotetext{
* Number of patients entering study: medical 102, surgical 104.
}

+ Number of patients entering study: medical 240, surgical 262. 
carried a particularly severe hazard for subsequent infarction. These findings indicate that at present quantitative coronary angiography is required to assess risk in patients suspected of having LAD disease. An extra argument for performing coronary angiography is the finding that LAD coronary arterial obstruction is frequently associated with disease in other coronary arteries. In our own series of 180 patients presenting with unstable angina and the ECG pattern indicating critical narrowing in the proximal LAD additional disease in 1 or 2 other coronary arteries was present in 37 and $21 \%$ respectively (12).

\section{How to diminish the risk:}

Data are available which illustrate that patients with proximal LAD disease have a better survival when treated by coronary bypass surgery.

The data from the European Coronary Surgery Study $(17,18)$ show an improved survival with surgery in patients having mild to moderate angina pectoris and a stenosis in the proximal one-third of the LAD as a component of either 2-vessel or 3-vessel disease (table 2). This is also true in patients with unstable angina and a proximal LAD lesion (19). Benefit from surgery over medical management increases when left ventricular dysfunction is present as in patients with unstable angina and stunned myocardium (20).

More information is needed about prognosis and treatment of the asymptomatic patient with an isolated proximal LAD stenosis, especially in those having silent ischemia on Holter monitoring or exercise testing (21-23).

In conclusion we believe that all patients with proximal LAD stenosis, leading to symptoms of myocardial ischemia or the ECG changes discussed above, should be considered candidates for coronary reperfusion (for instance by coronary bypass grafting or PTCA (24)). The value of these interventions in the asymptomatic patient requires further study.

A high incidence of thrombosis has been reported in patients with unstable angina (25-26). The short and long term benefit of thrombolytic therapy in patients with LAD disease presenting with unstable angina should also be evaluated.

\section{REFERENCES}

1. Edwards WD, Tajik AJ, Seward JB:

Standardized nomenclature and anatomic basis for regional tomographic analysis of the heart. Mayo Clin.Proc. 1981; 56:479-497.

2. Califf RM, Tomabechi $Y$, Lee KL, Phillips $\mathrm{H}$, Pryor DB, Harrell FE Jr., Harris PJ, Peter RH, Behar VS, Kong Y, Rosati RA:

Outcome in one-vessel coronary artery disease. Circulation 1983; 67: 283-290. 
3. Schuster EH, Griffith LSC, Bulkley BH*

Preponderance of acute proximal left anterior descending coronary arterial lesions in fatal myocardial infarction." a clinicopathologic study. Am.J.Cardiol. 1981; 47: $1189-1196$.

4. Brooks $N$, Cattell M, Jennings $K$, Balcon $R$, Honey $M$, Layton $C$ :

Isolated disease of left anterior descending coronary artery: angiographic and clinical study of 218 patients. Br. Heart J. 1982; 47: 71-77.

5. Chaitman BR, Davis K, Fisher LD, Bourassa MG, Mock MB, Lesperance J, Rogers WJ, Fray D, Tyras DH, Judkins MP, Ringvist J, Killip T:

A life table and cox regression analysis of patients with combined proximal left anterior descending and proximal left circumflex coronary artery disease: non-left main equivalent lesions (CASS). Circulation 1983; 68:1163-1170.

6. Taylor GJ, Humphries JO, Mellits ED, Pitt B, Schulze RA, Griffith LSC, Aschuff $\mathrm{SC}$ :

Predictors of clinical course, coronary anatomy and left ventricular function after recovery from acute myocardial infarction. Circulation 1980; 62: 960-970.

7. De Feyter PJ, Van Eenige MJ, Dighton DH, Visser FC, De Jong J, Roos JP: Prognostic value of exercise testing, coronary angiography and left ventriculography 6-8 weeks after myocardial infarction. Circulation 1982; 66: 527-536.

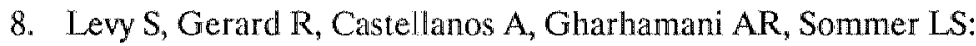

Transient left anterior hemiblock during angina pectoris: coronarographic aspects and clinical significance. Europ.J.Cardiol. 1979; 9:215-225.

9. de Zwaan C, Bär FWHM, Wellens HJJ:

Characteristic electrocardiographic pattern indicating a critical stenosis high in left anterior descending coronary artery in patients admitted because of impending myocardial infarction. Am. Heart J. 1982; 103: 730-735.

10. Haines DE, Raabe DS, Gundel WD, Wackers FJTh:

Anatomic and prognostic significance of new $T$ wave inversion in unstable angina. Am.J.Cardiol. 1983; 52: 14-18.

11. Boden WE, Bough EW, Benham J, Shulman RS:

Unstable angina with episodic ST segment elevation and minimal creatine kinase release culminating in extensive occurrent infarction. J.Am.Coll.Cardiol. 1983; 2: $11-20$. 
12. de Zwaan C, Bär FW, Janssen JHA, Cheriex EC, Dassen WRM, Brugada P, Penn OCKM, Wellens HJJ:

Angiographic and clinical characteristics of patients with unstable angina showing an electrocardiographic pattern pointing to a critical narrowing in the left anterior descending coronary artery. Am.Heart J., in press.

13. de Zwaan C, Cheriex EC, Braat SHJG, Stappers JLM, Bauer LHB, Wellens HJJ: Left ventricular wall motion in patients treated for unstable angina showing an electrocardiographic pattern pointing to critical narrowing in the proximal left anterior descending coronary artery. Submitted for publication.

14. Presti CF, Feigenbaum H, Armstrong WF, Ryan T, Dillon JC:

Digital two-dimensional echocardiographic imaging of the proximal left anterior descending coronary artery. Am.J.Cardiol. 1987; 60:1254-1259.

15. Yamagishi M, Miyatake K, Beppu S, Kumon K, Suzuki S, Tanuka N, Nimura Y. Assessment of coronary blood flow by transesophageal two-dimensional pulsed doppler echocardiography. Am.J.Cardiol. 1988; 62:641-644.

16. Ellis S, Alderman E, Cain K, Fisher L, Sanders W, Bourassa M, and the CASS investigators.

Prediction of risk of anterior myocardial infarction by lesion severity and measurement method of stenoses in the left anterior descending coronary distribution. A CASS registry study. J.Am.Coll.Cardiol. 1988; 11:908-916.

17. European Coronary Surgery Study Group:

Long-term results of prospective randomized study of coronary artery bypass surgery in stable angina pectoris. Lancet 1982;2: 1173-1180.

18. Varnauskas E, and the European Coronary Surgery Study Group.

Twelve-year follow-up of survival in the randomized European Coronary Surgery Study. N.Eng.J.Med. 1988; 319:332-337.

19. Rahimtoola SH, Nunley D, Grunkemeyer G, Tepley J, Lambert L, Starr A. Ten-year survival after coronary bypass surgery for unstable angina. N.Engl.J.Med. 1983; 308: 676-681.

20. Mock MB, Fisher LD, Holmes DR, Gersh BJ, Schaff HV, McConney M, Rogers WJ, Kaiser GC, Ryan TJ, Meyers WO, Killip III T and participants in the CASS. Comparison of effects of medical and surgical therapy on survival in severe angina pectoris and two-vessel coronary artery disease with and without left ventricular dysfunction: A CASS registry study. Am.J.Cardiol. 1988; 61: 1198-1203. 
21. Dearfield JE, Maseri A, Selwyn AP, Ribeiro P, Chierchia S, Krikler S, Morgan M: Myocardial ischemia during daily life in patients with stable angina; its relation to symptoms and heart rate changes. Lancet 1983; 2:753-758.

22. Gottlieb SO, Weisfeldt ML, Ouyang P, Mellits ED, Gerstenblith G.

Silent ischemia as a marker for early unfavourable outcomes in patients with unstable angina. N.Engl.J.Med. 1986; 314:1214-1219.

23. Nademanee K, Intarachot V, Josephson MA, Rieders D, Vaghaimalla-Mody F, Singh BN.

Prognostic significance of silent myocardial ischemia in patients with unstable angina. J.Am.Coll.Cardiol. 1987; 10:1-9.

24. Leeman DE, McCabe CH, Faxon DP, Lorell BH, Kellett MA, McKay RG, Varricchione T, Baim DS.

Use of percutaneous transluminal coronary angioplasty and bypass surgery despite improved medical therapy for unstable angina pectoris. Am.J.Cardiol. 1988; $61: 38 \mathrm{G}-44 \mathrm{G}$.

25. Sherman CT, Litvack F, Grundfest W, Lee M, Hickey A, Chaux A, Kass R, Blanche C, Matloff J, Morgenstern L, Ganz W, Swan HJC, Forrester J.

Coronary angioscopy in patients with unstable angina pectoris. N.Engl.J.Med. 1986; $315: 913-919$.

26. de Zwaan C, Bär FWHM, Janssen JHA, de Swart HB, Vermeer F, Wellens HJJ: Effects of thrombolytic therapy in unstable angina: clinical and angiographic results. Am.Coll.Cardiol. 1988; 12: 301-309 


\section{Left ventricular wall motion in patients treated for unstable angina showing an electrocardiographic pattern indicating critical narrowing of the proximal left anterior descending coronary artery.}

Chris de Zwaan MD and Emile C. Cheriex MD; Simon HJG Braat MD; Jan LM Stappers MD; Leo HB Bauer MD; Hein JJ Wellens MD.

Submitted for publication

\section{$\overline{\text { ABSTRACT }}$}

Effect of anti-ischemic treatment on left ventricular wall motion was stuclied in 35 patients (pts) with unstable angina pectoris and an electrocardiogram (ECG) indicating severe proximal left anterior descending coronary artery ( $L A D)$ narrowing. Treatment consisted of either a revascularization procedure (17 pts) or anti-anginal drug therapy (18 pts). All patients underwent two-dimensional (2D) echocardiographic studies within 48 (mean 20) hours of entry into the study. In 1.6 patients this investigation was combined with an apical interventricular septal wall motion study using M-mode echocardiography. A repeat ultrasonic study was performed at least 1 month (median 2 months 7 days) after admission.

Semi-quantitative wall motion analysis was performed:

In the $2 \mathrm{D}$ study a score was based on the systolic motion of the ischemia-related left ventricular segments. In both treatment groups patients showed significant improvement in wall motion of the anterior and apical segments.

In the M-mode study the classification was based on the pattern of both systolic and early diastolic excursion of the apical interventricular segment. Likewise, patients demonstrated significant amelioration in myocardial function.

The data indicate that regional myocardial function improves in the majority of patients admitted for unstable angina having an ECG pattern indicating severe proximal LAD disease and successfully treated by revascularization or anti-anginal drug therapy.

\section{INTRODUCTION}

In 1982 we reported on a typical electrocardiographic (ECG) pattern indicating critical reduction in flow in the left anterior descending coronary artery (LAD) in patients admitted to hospital because of unstable angina (1). The characteristic ECG is composed of abnormal ST segments and negative $T$ waves in the precordial leads $V_{2}$ and 
$V_{3}$ in the absence of pathologic $Q$ waves (1). The ECG abnormalities normalize in ninety percent of cases within 60 days (2).

Contrast left ventricular angiography showed a high incidence of abnormal systolic anteroseptal wall motion in these patients. The incidence was significantly related to the time interval between the last attack of chest pain and cardiac catheterization. Also, an abnormal diastolic anteroseptal wall motion was observed in $85 \%$ of the patients. These observations suggested that the electrocardiographic and angiographic abnormalities were caused by hibernating or stunned myocardium (2).

M-mode and two-dimensional echocardiography have been shown to be accurate noninvasive methods to detect and quantify regional wall motion abnormalities in the setting of acute myocardial infarction (3-5). However, the use of serial echocardiography to assess the recovery of regional wall motion in patients with unstable angina has seldomly been reported (6). The purpose of the present study was to evaluate the effect of anti-ischemic treatment on left ventricular function in patients with unstable angina pectoris consequent to severe proximal LAD disease and to identify those likely to have a less favourable outcome.

\section{METHODS}

\section{Patient selection}

Thirty-eight patients underwent an echocardiographic study after hospitalization for unstable angina. To be included in the study the patient had to undergo an echocardiographic study within 2 days of presentation and another one a minimum of one month after admission. Three patients suffered a myocardial infarction before the repeat ultrasonic study and were excluded from follow-up. The remaining thirty-five patients constituted the study population.

They all fulfilled the following criteria $(1,2)$ :

1) Typical ischemic chest pain, with a severity of functional Class III or IV according to the New York Heart Association Classification. 2) Typical ST segment and T wave abnormalities in at least the precordial leads $V_{2}$ and $V_{3}$ (see figure 1) outside an episode of chest pain. 3) Serial enzyme values for creatine kinase (CK), measured 8 hourly for 3 consecutive days, with a maximal value of less than twice the upper limit of normal. 4) A coronary angiogram quantifying the stenosis severity in the proximal left anterior descending coronary artery.

Seventeen of the 35 patients underwent revascularization (coronary bypass surgery in 14 patients, coronary angioplasty in 3 patients) with a median of 11 days after hospital admission. All these patients had early revascularization and were operated upon because of triple vessel disease ( 6 patients), refractoriness to conventional medical treatment ( 5 patients) or because of a large area at risk without collateral circulation $(1,2)$. These patients had their late echocardiographic study a median of 3 months 20 days after revascularization. Eighteen patients were treated with "conventional" drug therapy including a beta-adrenergic blocking agent (metoprolol), a nitrate (isosorbidedinitrate) and antiplatelet drugs (asperin, dipyridamole). A calcium channel blocker (nifedipine) was given when indicated. They had their repeat ultrasonic study a median 


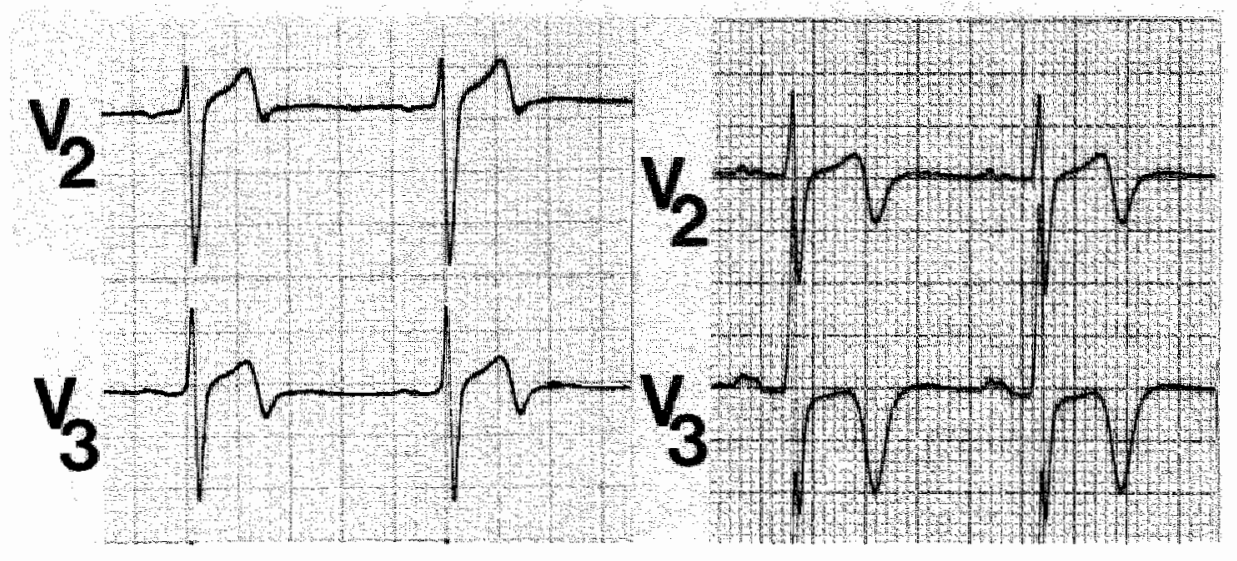

FIGURE 1: The two typical ECG patterns found in the precordiall leads $V_{2}$ and $V_{3}$ in the patients reported.

of 1 month 29 days after hospital admission. No patient of the study population suffered myocardial infarction between the early and late echocardiographic investigation.

In 28 patients a Thallium-201 myocardial perfusion scintigraphy was performed at rest on the same day as the early echocardiographic study.

\section{Echocardiographic studies}

Studies were performed during a painfree period within 2-48 hours (mean 20 hours) of entry into the study and again at a minimum of one month (a median of 2 months 7 days) after admission. Echocardiograms were obtained using commercially available 2D echocardiographic equipment (Hewlett Packard $77020 \mathrm{~A}(\mathrm{C})$ ). All studies were technically adequate for scoring regional endocardial wall motion.

2 D studies: Two-dimensional echocardiograms were recorded on video tape (VHS) to allow semi-quantitative analysis later. The 2D study consisted of the parastemal long and short-axis view, the apical two and four chamber and long-axis view. To assess changes in regional myocardial function, the left ventricular wall was divided into 13 segments. Six areas were divided into a basal and an apical segment (anteroseptal: segment 1,2, anterior 3,4, lateral 5,6, posterior 7,8, inferior 9,10 and inferoseptal 11,12). Also an apical segment (segment 13) was defined. Segmental wall motion was semiquantitatively evaluated using the real time, slow motion and still frame images. A numerical score was assigned to each ischemia related segment (segments $1,2,3,4$ and 12,13 ) according to the degree of asynergy. The score was given as follows: score 0 for normal, 1 for slight hypokinesis with minor decrease in endocardial thickening, 2 for moderate hypokinesis, 3 for severe hypokinesis, 4 for akinesis and 5 for dyskinesis. The score for each segment was used to calculate a total wall motion score by adding the scores of all "ischemia related" segments. 

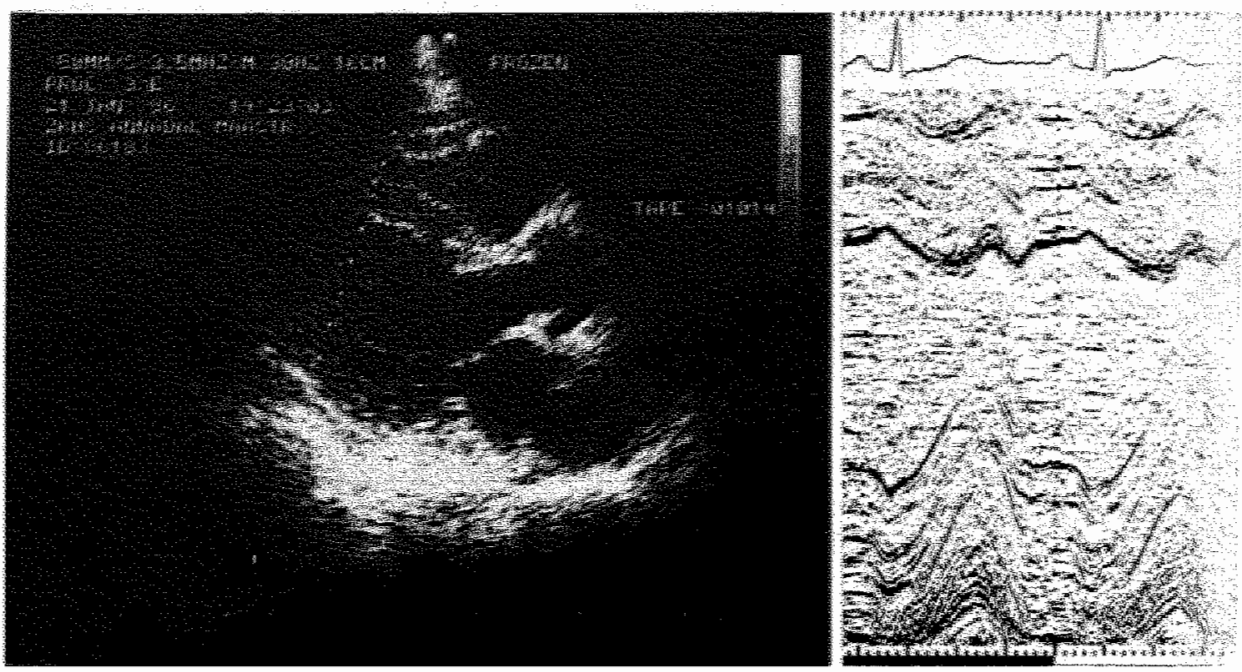

FCURE 2: Whistration of the drection of the uhtrasonie beam for estimation for the apreal interwentricular sepula excursion (M-mode study) and an exmple of this tereursion.

The semi-quantitative interpretation of regional myocardial function was done by wo individuals without knowledge of the temporal secquence in which the studies were acquired.

M-mode stadies: During $2 \mathrm{D}$ echocardiography we observed the sume abnormal diastolic anteroseptal wall motion as seen during contrast teft ventricular angiography (2). We therefore paid special attention to the motion of the frequently involved apical interventricular septum in systole and early diastole using $M$-mode registration. A stripchart recorder (Hewlett Packard $77500 \mathrm{C}$ ) was adapted for analysis. For this purpose the transducer was placed parasternally. The ultrasonic beam was directed toward the apical interventricular septal segment as perpendicular to this segment as possible (figure 2). Both posterior excursions of the endocardial border in systole and early diIstole were semi-quantitatively estimated. The analysis was based on a wall motion pattern, giving a typification: type I-II for normal, III-IV for near normal and abnormal pronounced early diastolic excursion, V-VI for decreased systolic and pronounced early diastolic excursion and VII for dyskinetic excursion (figure 3). The time interval between the initial activity of the ORS complex (or the $\mathrm{R}$ wave on the right precordial ECO) and the peak systolic and (if present) peak early diastolic excursion of the apical interventricular septum were measured.

Also the thickness of the apical interventricular septum (WS) in systole(s) and diastole(d) was analyzed and the maximal posterior excurston of the endocardial border of this apical interventricular septum nystole and early diastole was investigated. 


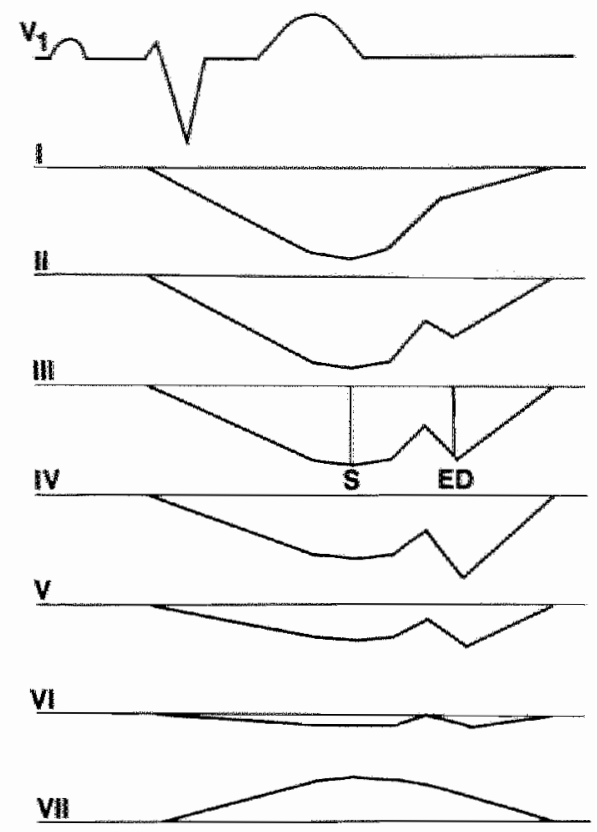

FIGURE 3: The seven patkerns of systolic and earty diastolic septal wall excursion (M-mode study, see text). $\mathrm{S}=$ systolic; $\mathrm{ED}=$ earty diastolic.

In addition, the basal left ventricular internal dimension in systole(s) and diastole(d) was analyzed. These measurements were done according to the ASE recommendations (7).

By way of the apical interventricular septal wall thicknesses (IVS d,s) and the basal left ventricular internal dimensions (LVID $d, s$ ) the septal percent thickening (IVS $d$ IVS $s$ : IVS $d x$ 100) (8) and the fractional shortening (LVID d - LVID s : LVID $d x$ 100)(9) were calculated respectively.

The results of the M-mode study were compared to values of a healthy population of 22 persons with normal coronary arteries, having no muscular or valvular disease, and the same distribution of age and sex (table 2).

\section{Statistics}

Data are expressed as mean \pm standard deviation. Quantitative improvement of results in the ischemia related segments (according to the M-mode study) and semi-quantitative differences in initial and final wall motion scores and types (according to the $2 \mathrm{D}$ and M-mode studies) were compared by means of Student's paired and unpaired Ttest. 


\section{RESULTS}

\section{Clinical and angiographic findings}

The clinical characteristics are listed in table 1. In $54 \%$ of patients the severity of angina was classified as being Class IV (anginal attacks at rest). The last attack of pain had occurred 5.6 hours (mean) before entry into the study and had lasted an average of 24 minutes. The mean value in the 9 patients with a small rise in maximal $\mathrm{CK}$ value was $314 \mathrm{IU} / \mathrm{L}$ (upper limit of normal: $240 \mathrm{HU} / \mathrm{L}$ ). No patient had coronary bypass surgery or angioplasty in the past.

A lesion in the proximal LAD was the only abnormality in 14 patients. Fourteen cases had additional disease in another vessel and 7 patients in the remaining 2 vessels. Ten patients had their site of most severe narrowing proximal to the first, 20 cases proximal to the second septal branch. The LAD was completely obstructed in 4 patients. The mean diameter narrowing of the 31 non-occluded vessels was 85 percent. No distal filling within 3 cardiac cycles over the stenosis in the LAD was anterogradely observed in 5 of 31 patients. Collateral circulation was present in all 4 patients having a totally obstructed $\mathrm{LAD}$ and in 11 patients having vessels with a $80-99$ percent diameter narrowing.

Apart from refractoriness to medical treatment and a not significantly higher incidence of three vessel disease the revascularized patients had no significant differences in other clinical characteristics or angiographic findings compared to the conventionally treated patients.

TABLE 1: Clinical characteristics of all 35 patients

\begin{tabular}{|c|c|c|}
\hline \multicolumn{2}{|l|}{ Age in years, mean $\pm S D$} & $56 \pm 9$ \\
\hline \multicolumn{2}{|l|}{ Sex (malc:female) } & $26: 9$ \\
\hline \multicolumn{2}{|l|}{ Previous nyyocardial infarction } & 1 \\
\hline \multicolumn{2}{|l|}{ Previous angina pectoris } & 18 \\
\hline \multirow[t]{2}{*}{ Severity of AP on eniry } & - Class III & 16 \\
\hline & - Class IV & 19 \\
\hline \multicolumn{2}{|c|}{ Duration of unstable angina on entry in days, median } & 4 \\
\hline \multicolumn{3}{|c|}{ Time interval between last attack of chestpain and } \\
\hline \multirow[t]{2}{*}{ Creatine kinase } & $-1 x$ to $2 x$ upper limit of normal & 9 \\
\hline & - normal & 26 \\
\hline \multirow[t]{3}{*}{ Thallium-201-uptake at rest } & - diminished & 8 \\
\hline & normal & 20 \\
\hline & - unknown & 7 \\
\hline
\end{tabular}

$A P=$ angina pectoris. 


\section{Echocardiographic findings}

2D studies: All patients underwent serial two-dimensional echocardiographic studies. Findings of the revascularized (group I) and medically treated patients (group II) are given in figure 4.

In the early study the mean total wall motion score of group I having a more diseased coronary artery system was not significantly higher as compared to the value of group II $(6.9 \pm 4.8$ vs $4.6 \pm 4.6$, respectively $)$.

During follow-up the wall motion remained normal in 5 and normalized in 15 patients of the total study population. In 11 patients the wall motion score decreased (to values greater than or equal to 1) while in 2 cases an increase was noticed. Two scores remained unalteredly elevated. The improvement in regional wall motion was significant $(\mathrm{p}<0.001)$ in both study groups. The amelioration was mainly present in segments 2,4 and 13 .

M-mode studies: The M-mode echocardiographic findings of the patients are listed in table 2. Apical myocardial function improved significantly $(\mathrm{p}<0.001)$ from abnormal to near normal, according to the pattern of the interventricular septal excursion. An example is given in figure 5. The time interval between the peak systolic and (if present) peak early diastolic excursion became less (prolonged) on repeat examination.
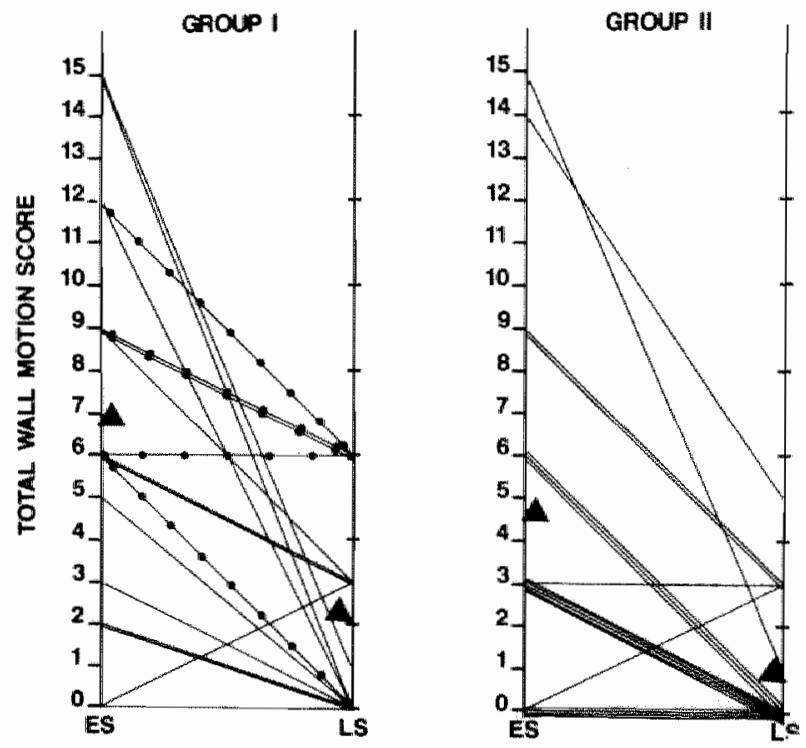

FIGURE 4: Changes in total wall motion score in patients undergoing either revascularization (group I) or anti-ischemic drug treatment (group II). (2D study).

Dotted lines represent patients who were refractory for medical therapy and operated upon. Closed triangles represent the mean walue of wall motion score for each group; In both groups the differences in mean values of the early (ES) and late study (LS) were statistically significant ( $p<0.001$ ). 
TABLE 2: Early and late M-mode echocardiographic findings of patients compared to 22 normal controls

Normal

controls

$\frac{\text { Study population }}{\text { Early }} \quad$ P value

\begin{tabular}{|c|c|c|c|c|}
\hline \multicolumn{5}{|l|}{ APICALIVS EXCURSION * } \\
\hline systolic excursion in mm & $9.3 \pm 1.1$ & $6.4 \pm 3.3$ & $7.8 \pm 3.0$ & \\
\hline early diastolic excursion present in \% & 36 & 100 & 69 & \\
\hline if present in mm & $6.6 \pm 1.0$ & $5.8 \pm 2.6$ & $6.7 \pm 2.0$ & \\
\hline heart rate per minute & $75 \pm 18$ & $65 \pm \mathbb{1}$ & $68 \pm 1.5$ & \\
\hline R-systolic excurstion in msec. & $352 \pm 51$ & $325 \pm 34$ & $364 \pm 60$ & $<0.05$ \\
\hline R-early diastolic excursion in msec. & $441 \pm 32$ & $491 \pm 45$ & $505 \pm 33$ & \\
\hline \multicolumn{5}{|l|}{ APICAL IVS THICKNESS ${ }^{*}$ : } \\
\hline diastole in mm & $6.1 \pm 0.8$ & $6.8 \pm 0.7$ & $6.7 \pm 0.7$ & \\
\hline systole in mm & $9.4 \pm 1.2$ & $8.8 \pm 1.2$ & $9.9 \pm 1.1$ & \\
\hline percent thickening & $54 \pm 18$ & $31 \pm 18$ & $48 \pm 12$ & $<0.005$ \\
\hline \multicolumn{5}{|l|}{ BASAL LVID ${ }^{++4}$ : } \\
\hline diastole in mm & $47 \pm 4$ & $50 \pm 4$ & $49 \pm 4$ & \\
\hline systole in mm & $30 \pm 4$ & $32 \pm 25$ & $31 \pm 4$ & \\
\hline fractional shortening & $37 \pm 4$ & $37 \pm 6$ & $38 \pm 5$ & \\
\hline
\end{tabular}

IVS $=$ interventricular septal; LVID $=$ left ventricular internal dimension;

$+: 16$ patients; $+4: 35$ patients; $*$ = late ws early study.

In the follow-up echocardiogram there was an increase in apical septal thickness during systole, resulting in an increase in percent thickening of this segment compared to the baseline study $(\mathrm{p}<0.005)$.

The basal left ventricular internal dimensions in the early study were not different from those during the late investigation, or the values from the healthy controls.

In no case left ventricular hypertroplay or valvular disease was diagnosed.

\section{Clinical course}

During the time interval between hospital admission and the late echocardiographic study 17 patients were revascularized.

Three of 17 revascularized patients suffered very limited myocardial injury "during" operation as shown by a minimal rise in CK value. This finding was not accompanied with the development of a $\mathrm{Q}$ wave or a change in $\mathrm{R}$ wave voltage on the ECG.

At the time of the second echocardiographic investigation 10 patients had angina Class II and one man complained of angina pectoris at slight excercise (Class III). The remaining 24 patients were free of angina. 

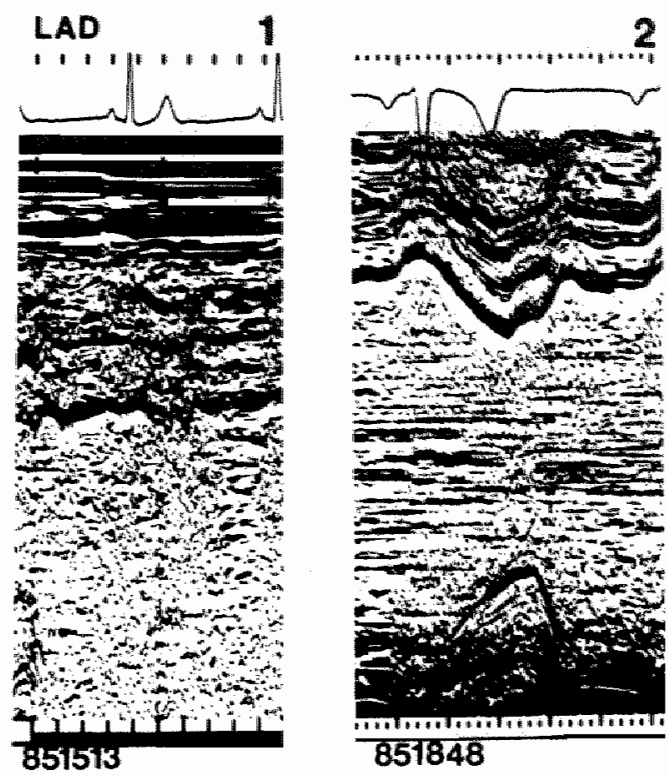

Figure 5: Two types of systolic and early diastolic septal wall excursion of the carly (left panel) and late (right panel) $M$-mode study in the same patient.

1) Left panel - paper-speed $25 \mathrm{~mm} / \mathrm{sec}$; wall motion-pattern = type $\mathrm{V}$

2) Right panel - paper-speed $50 \mathrm{~mm} / \mathrm{sec}_{;}$wall motion-pattern = type II

During follow-up (mean duration 2.7 years) and after the late echocardiographic study another 3 patients were revascularized because of refractoriness to medical therapy. Another patient suffered a non fatal acute anterior wall myocardial infarction and one patient died suddenly. Four of the 5 patients with a cardiac event following the repeat ultrasonic examination had a normal systolic wall motion pattern at the late 2D study.

Thirty-four patients regained a normal ST-T segment on the ECG over time: 19 of them at the first visit to the out-patient clinic, 15 of them later (mean time interval between hospital admission and normalized ECG: 4.4 weeks and 3.4 months respectively).

All 8 patients showing a diminished uptake of Thallium-201 at rest on the early study did not show that defect on repeat myocardial perfusion scintigraphy during follow-up.

\section{DISCUSSION}

For many years it has been accepted that imbalance of the myocardial oxygen supply/demand relation could lead to two patterns of clinical, electrocardiographic, biochemical and mechanical features of acute ischemia: 
1) Rapid reversal of changes when myocardial oxygen balance was restored before irreversible injury developed, 2) irreversible myocardial damage when the duration of ischemia was prolonged beyond a critical point.

It is now clear that the effects of ischemia on the myocardium are more complex. Rather than causing these two principal syndromes we now recognize two additional syndromes: prolonged postischemic cardiac dysfunction after acute ischemia (myocardial stunning) (10) and severe persistent cardiac dysfunction secondary to chronic ischemia with viable though poorly contractile myocardium (cardiac hybernation) (11).

We previously reported on a typical ECG pattern in patients with unstable angina indicating a critical reduction in flow in the LAD and an abnormal regional myocardial function $(1,2)$. The ECG pattern normalized in $90 \%$ of cases within a limited period of time. In that angiographic study a significant difference $(p<0.001)$ in mean duration of time interval between the last attack of chest pain and catheterization was present between the group with an abnormal $(4.1 \pm 2.5$ days) compared to the patients with a normal systolic left ventricular wall motion $(6.4 \pm 3.3$ days). That finding suggested to us the presence of myocardial stunning. We also observed in $85 \%$ of cases abnormalities in diastolic ventricular function (2).

Echocardiography has been shown to be of value to detect left ventricular wall motion abnormalities induced by myocardial ischemia. Both $\mathrm{M}$-mode and $2 \mathrm{D}$ echocardiographic techniques accurately identify myocardial dysfunction in acute and chronic ischemic heart disease in humans (3-6). Furthermore, serial echocardiographic studies after acute myocardial infarction identify a reduction in the extent of regional dysfunction caused by diminishing peri-infarctional ischemia (12-14).

The present study describes the experience in 35 patients with unstable angina and an impending anterior wall infarction. It shows that serial regional 2D and M-mode echocardiographic examinations detect transient and persistent left ventricular segmental wall motion abnormalities.

2D studies: The initial 2D echocardiographic technique revealed a (not significantly) higher total wall motion score in the revascularized group (group I) as compared to the conventionally treated group (group II), possibly influenced by a (not significantly) higher incidence of 3-vessel disease in the former group ( $6 \mathrm{vs} 1$ patient).

The transient wall motion abnormalities in 15 patients can be interpreted as regional segmental dysfunction induced by previous acute ischemia (myocardial stunning). An illustration of the transient ischemia can be the normalization of Thallium-201 uptake in 8 restudied patients (showing a mean total wall motion score of 7.0 in the early and 1.9 in the late 2D echocardiographic study).

Incomplete recovery was present in 11 patients and worsening of segmental dysfunction was observed in 2 patients. These persistent abnormalities may represent continuing "asymptomatic" ischemia (cardiac hybernation). This possibility is consistent with reports that many patients with unstable angina progress to coronary occlusion within a limited period of time (15). Another explanation can be that in patients still suffering from angina pectoris these abnormalities may represent small areas of new myocardial necrosis not recognizable with conventional clinical methods (16). This could have been the case in four patients who had a wall motion score of 6 in the late study. They formed $80 \%$ of patients who were refractory to conventional medical therapy and 
who had to be treated with early bypass surgery. A third explanation can be that surgical intervention may have resulted in a small amount of myocardial injury (in 3 of 9 possible cases documented by enzyme changes). And lastly a persistently elevated wall motion score may also represent old myocardial injury. Although we tried to exclude patients who might have suffered from a previous anterior wall infarction, we cannot exclude that previous injury may have escaped detection by clinical means.

M-mode studies: The initial semi-quantitative M-mode echocardiographic technique revealed a "pronounced" septal dip caused by an increased early diastolic septal excursion in the presence of a decreased systolic septal excursion. In the late quantitative studies there was a recovery of systolic excursion and in 5 of 16 patients a disappearance of the pronounced early diastolic excursion. These findings were responsible for the significant change in type of apical interventricular septal excursion pattern according to the semi-quantitative analysis of the M-mode studies.

"Prolongation" of the relaxation pattern in the early study was caused by a shorter time interval from the beginning of the QRS complex to the diminished (and maybe nat complete) peak systolic excursion compared to the for heart rate adjusted value of healthy controls. During follow-up the time interval from $\mathrm{R}$ wave to peak systolic excursion normalized, resulting in a decrease of the "prolongation" of the relaxation pattern.

Experimental studies of regional myocardial function in animals and humans have documented transient abnormalities of diastolic left ventricular wall motion after coronary arterial occlusion. Przyklenk et al (17) reported diastolic abnormalities of postischemic "stunned" myocardium in 9 anesthetized open-chest dogs. Left ventricular pressure vs segment length loops showed that the systolic contraction, isovolumic relaxation and diastolic relaxation time were impaired for at least 3 hours after a brief, transient period of occlusion of the proximal LAD. A recent article by Wijns et al (18) suggests that abnormalities in diastolic function persist beyond the recovery of normal systolic function in patients rendered ischemic for brief periods during percutaneous transluminal coronary angioplasty.

In 20 to $30 \%$ of healthy human beings the early diastolic excursion of a septal dip can be provoked or exaggerated by respiration. This observation suggests that RV volume and prolongation of RV ejection time may play a role in the normal variation of the diastolic dip. An abnormal variation of the early diastolic excursion (or M-mode wall motion excursion type III-VI) may develop as a result of delay in RV contraction leading to a posterior excursion of the interventricular septum during early diastolic LV relaxation. This mechanism can be the result of ischemia of the right bundle branch fibers, vascularized by the moderator band artery, a proximally located septal branch of the LAD (19).

The early M-mode echocardiographic study showed a diminished increase in systolic septal thickness. However, paradoxical septal thinning (20) was never observed. In the late study systolic thickness and percent thickening returned to near normal values.

Basal left ventricular internal dimensions and fractional shortening remained normal in both early and late examinations. This indicates that the fractional shortening cannot be used as a guide to severity of ischemia. This has already been shown in laboratory studies in dogs (20). 
Prognosis: Approximately one-third to one-fourth of patients with unstable angina subsequently develop episodes of intractable angina pectoris $(15,21)$. Several clinical features have been implicated as predictors of an unfavourable course during followup (22). In our study with a mean duration of follow-up of 2.7 years 17 patients had early and 3 patients late revascularization. After the repeat echocardiographic examination one patient suffered a non fatal acute anterior wall myocardial infarction and one died suddenly. Four of the 5 patiënts with a cardiac event following the late $2 \mathrm{D}$ ultrasonic study showed a normal systolic wall motion score according to this technique. The limited number of patients and the short duration of follow-up did not allow us to find parameters able to identify those most likely to have a less favourable outcome after hospital discharge.

\section{$\overline{\text { CONCLUSION }}$}

This study shows that regional myocardial function improves in the majority of patients treated for unstable angina showing an ECG pattern indicating proximal LAD disease. Improvement was independent of type of anti-ischemic treatment (bypass surgery, PTCA or drugs) and correlated with clinical characteristics. Serial M-mode and 2D echocardiography is of help to document that improvement.

\section{Acknowledgment}

The authors express their gratitude to Dr. Cees A. Visser for his suggestions during the preparation of this manuscript and to Mrs. Andrea P. Palmans-Meulemans for technical assistance. 


\section{REFERENCES}

1. de Zwaan C, Bär FW, Wellens HJJ:

Characteristic electrocardiographic pattern indicating a critical stenosis high in left anterior descending coronary artery in patients admitted because of impending myocardial infarction. Am. Heart J. 1982; 103: 730-735.

2. de Zwaan C, Bär FW, Janssen JHA, Cheriex EC, Dassen WRM, Brugada P, Penn OCKM, Wellens HJJ:

Angiographic and clinical characteristics of patients with unstable mgina showing an electrocardiographic pattern pointing to a critical narrowing in the left anterior descending coronary artery. Am.Heart J.; accepted for publication $(1989 ; 117$ :-).

3. Weiss JL, Bulkley BH, Hutchins GM, Mason SJ:

Two-dimensional echocardiographic recognition of myocardial injury in man: comparison with postmortem studies. Circulation 1981; 63: 401-408.

4. Visser CA, Lie KI, Kan G, Mellzer R, Durrer D:

Detection and quantification of acute, isolated myocardial infarction by two-dimensional echocardiography. Am.J. Cardiol. 1981; 47: 1020-1025.

5. Horowitz RS, Morjanroth J, Parotto C, Chen CC, Soffer J, Pauletto FJ:

Immediate diagnosis of acute myocardial infarction by two-dimensional echocardiography. Circulation 1982; 65: 323-329.

6. Nixon JV, Brown CN, Smitherman TC:

Identification of transient and persistent segmental wall motion abnormalities in patients with unstable angina by two-dimensional echocardiography. Circulation $1982 ; 65: 1497-1503$.

7. Sahn DJ, DeMaria A, Kisslo J, Weyman A: The committee on M-mode standm ardization of the American Society of Echocardiography. Recommendations regarding quantitation in M-mode echocardiography: Results of a survey of echocardiographic measurements. Circulation 1978; 58: 1072-1083.

8. Henry WL, Ware J, Gardin JM, Hepner SJ, McKay J, Weiner M: chocardiographic measurements in normal subjects. Circulation 1978; 57:278-285.

9. Quinones MA, Pickering E, Alexander JK:

Percentage of shortening of the echocardiographic left ventricular dimension. Its use in determining ejection fraction and stroke volume. Chest 1978; 74: 59-65.

10. Braunwald E, Kloner RA:

The stunned myocardium: prolonged, postischemic ventricular dysfunction. Circulation 1982; 66: 1146-1149. 
11. Rahimtoola SH:

A perspective on the three large multicenter randomized clinical trials of coronary bypass surgery for chronic stable angina. Circulation 1985; 72: V123-135.

12. Charuzi $Y$, Beeder C, Marshall LA, Sasahi H, Pack NB, Geft J, Ganz W: Improvement in regional and global left ventricular function after intracoronary thrombolysis: assessment with two-dimensional echocardiography. Am. J. Cardiol. 1984; 53: 662-665.

13. Topol EJ, Weiss JL, Brinker JA, Brin KP, Gottlieb SO, Becker LC, Bulkley BH, Chandra N, Flaherty JT, Gerstenblith G, Gottlieb SH, Guera AD, Ouyang P. Llewellyn MP, Weisfeldt ML, Shapiro EP:

Regional wall motion improvement after coronary thrombolysis with recombinant tissue plasminogen activator: importance of coronary angioplasty. J. Am. Coll. Cardiol. $1985 ; 6: 426-433$.

14. Presti CF, Gentile R, Armstrong WF, Ryan T, Dillon JC, Feigenbaum H:

Improvement in regional wall motion after percutaneous transluminal coronary angioplasty during acute myocardial infarction: utility of two-dimensional echocardiography. Am. Heart J. 1988; 115: 1149-1155.

15. Neil] WA, Wharlon TP, Fluri-Lundeen J, Cohen JS:

Acute coronary insufficiency-coronary occlusion after intermittent ischemic attacks. N. Eng. J. Med. 1980: 302: 1157-1162.

16. Ninomiya K, Hashida J, Geft J, Chaux E, Shell W, Fischbein MC, Ritt J, Yano J, Ganz W:

Brief repeat episodes of ischemia have a cumulative effect and may cause myocardial necrosis. Am. J. Cardiol. 1981; 47: 445 (abstract).

17. Przyklenk K, Patel B, Kloner RA:

Diastolic abnormalities of postischemic "stunned" myocardium. Am. J. Cardiol, 1987; 60: 1211-1213.

18. Wijns W, Serruys PW, Slager CJ, Grimm J, Krayenbuehl HP, Hugenholtz PG, Hess OM:

Effect of coronary occlusion during percutaneous transluminal angioplasty in humans on left ventricular chamber stiffness and regional diastolic pressure-radius relations.

19. Haupt HM, Hutchins GM, Moore GW:

Right ventricular infarction: Role of the moderation band artery in determining infarct size. Circulation 1983; 67: 1268-1272. 
20. Verani MS, Bolli R, Tadros S, Myers ML, Borges Neto S, Jain A, Phillips L, Roberts R:

Dissociation between global and regional systolic and diastolic ventricular function during coronary occlusion and reperfusion. Am. Heart J. 1987; 114: 687-695.

21. HINT Research Group:

Early treatment of unstable angina in the coronary care unit: a randomised, double blind, placebo-controlled comparison of recurrent ischaemia in patients treated with nifedipine or metoprolol or both. Br. Heart J. 1986; 56: 400-413.

22. Plotnick GD:

Prognostic classification of the patient with rest angina. Unstable angina: a clinical approach. ISBN: No 0-87993-232-5. 



\section{Effects of thrombolytic therapy in unstable angina: clinical and angiographic results.}

Chris de Zwaan, MD, Frits W. Bär,MD, Johan H.A. Janssen, MD, Hans B. de Swart, MD, Frank Vermeer,MD, Hein J.J. Wellens, MD.

J.Am.Coll.Cardiol. 1988; 12: 301-309

\section{$\overline{\text { ABSTRACT }}$}

The incidence of intracoronary thrombus and the effects of thrombolytic therapy were studied in 41 patients with unstable angina. All patients underwent coronary angiography 2 to 69 hours (mean 19) after their last attack of chest pain. Immediately after angiography, 21 patients received intracoronary streptokinase $(250,000 \mathrm{IU}$ in 45 min.) and were retrospectively analyzed. Twenty patients received intravenous recombinant tissue-type plasminogen activator (rt-PA) (100 mg in 3 hours) and were involved in a prospective study.

Eleven of the 21 patients from the streptokinase group and 11 of the 20 patients from the rt-PA group showed a decrease in the severity of the coronary stenosis on repeat angiography 1 day later. A decrease in coronary obstruction was primarily observed in 10 of 13 patients with a complete stenosis and in 6 of 9 patients with a subtotal stenosis and markedly diminished coronary flow. Improvement in coronary anatomy was not determined by the clinical characteristics of the patients. Twenty-eight of the 41 patients had angiographic evidence of intracoronary thrombus formation before and 16 had such evidence after thrombolytic treatment. Nine patients developed a small increase in serum cardiac enzymes before or during treatment. Ischemic symptoms and the incidence of surgical or angioplastic intervention were not different in patients with or without reduction in coronary artery stenosis after fibrinolytic therapy.

These observations suggest a high incidence of coronary thrombosis in patients with unstable angina. The data do not permit assessment of the clinical therapeutic efficacy of thrombolytic therapy. Better risk stratification and placebo-controlled prospective studies are required to obtain information on the risk/benefit ratio of such therapy in unstable angina.

\section{INTRODUCTION}

In 65 to $90 \%$ of patients with acute myocardial infarction, a thrombotic obstruction is observed in the infarct-related coronary artery (1). Depending on the type of thrombolytic agent and the mode of administration, thrombolytic therapy results in recanaliza- 
tion of the infarct-related coronary artery in 40 to $88 \%$ of patients. This leads to limitation of infarct size, preservation of global and regional left ventricular function and improved 1 year survival (2-15).

In patients with unstable angina pectoris, angiographically detected intracoronary thrombosis has been described in a number of studies ( $16-22)$, with considerable variation in the reported incidence. In a recent study (23), angioscopy of the coronary arteries during coronary artery bypass surgery revealed a high prevalence of intracoronary thrombus in patients with unstable angina refractory to medical treatment. This was not observed in patients with stable angina.

In patients with unstable angina, administration of thrombolytic agents might be effective in dissolving the thrombus and improving coronary flow. Such intervention might result in a diminished risk of myocardial infarction and death. The purpose of the present study was to investigate the coronary artery anatomy in patients with unstable angina and to evaluate the effect of thrombolytic agents on coronary anatomy and outcome during hospital stay and during a 3 month follow-up period.

\section{METHODS}

\section{Patient Selection}

From March 1986 through February 1987, patients with unstable angina entered the study. Selective coronary arteriography and left ventriculography were required within 24 hours after admission to the hospital. The last episode of chest pain had to occur within 48 hours before hospital admission. If the patient had chest pain on or after admission, ischemic electrocardiographic (ECG) changes were criteria for entry into the study. If the patient had symptoms only before hospitalization and was admitted with the clinical diagnosis of unstable angina, he or she could be included into the study in the absence of ECG ST segment abnormalities.

In the first part of the study, 21 patients received intracoronary streptokinase in the artery thought to be responsible for the abnormal ECG and left ventricular angiogram (if present). Beside the artery had to be suitable for treatment with this kind of therapy, that means that a clot was thought to be present in this artery. These patients were retrospectively analyzed.

In the second part of the study, 26 patients with unstable angina were accepted for a prospective trial. In two patients, we were unable to perform cardiac catheterization. In four patients (three with a normal and one with an abnormal ECG after chest pain) no coronary artery disease was found at cardiac catheterization and, therefore, no fibrinolytic therapy was given. The remaining 20 patients received intravenous thrombolytic therapy and were analyzed.

According to studies $(3-6,11,12)$ in patients with acute myocardial infarction, the efficacy of the two thrombolytic agents (in terms of patency rate) is more or less the same if streptokinase is given in the intracoronary mode and rt-PA is administered intravenously. This was one of our reasons for combining the data for both treatment groups.

The study was approved by the hospital's institutional review board. 


\section{Diagnosis of Unstable Angina}

This diagnosis was made independently by two experienced cardiologists, and defined as angina of recent onset, sudden worsening of preexisting stable angina or postinfarction angina developing after an asymptomatic period of $\geq 3$ months and classified as New York Heart Association functional class III or IV. The symptoms of unstable angina had to start within the last 6 weeks before admission to hospital and could include repeated episodes of chest pain of long duration ( $>20$ minutes) at rest or after minimal exercise.

\section{Other Inclusion and Exclusion Criteria}

Inclusion criteria were age up to and including 70 years and disappearance or marked relief of pain after sublingual or intravenous nitroglycerin. Excluded were patients with severe valvular heart disease, (class III and IV) heart failure, pacemaker, anemia (hemoglobin $<5.5 \mathrm{mmol} /$ liter), heart rate $>100$ or $<50$ beats $/ \mathrm{min}$ at rest in the albsence of chest pain, arrhythmia-induced angina pectoris, contraindications for thrombolytic therapy or absence of consent. In addition to these clinical criteria, ECG and laboratory data were used to support the diagnosis of unstable angina.

\section{Electrocardiographic Findings}

All patients had a 12 lead ECG recorded on admission. When the patient had chest pain after hospital admission, tracings were also recorded during and after such an attack. These recordings were classified as showing only ST-T segment abnormalities, both QRS complex and ST segment abnormalities or no abnormalities at all. ST-T segment abnormalities were defined as ST segment changes cluring pain or after chest pain.

If the patient had angina on or after hospital admission, ECG changes were required. The ST segment changes during pain consisted of distinct elevation or depression of the ST segment (in, respectively, 11 and 7 patients). These changes had to disappear or markedly diminish spontaneously, after either sublingual or intravenous nitroglycerin. If the patient had chest pain before hospital admission, the ischemic ST-T segment abnormalities after chest pain consisted of an abnormal upsloping or downsloping ST segment in combination with an inverted T wave, or horizontal ST segment depression (in, respectively, 15 and 6 patients).

Patients with abnormal $Q$ waves were only accepted if there were previous electrocardiographic recordings documenting $Q$ waves that represented prior myocardial infarction. Two patients who had chest pain suggestive of unstable angina before admission but no ECG abnormalitis on admission were also entered into the study.

\section{Cardiac Enzyme Measurements}

Serial serum enzymes values for creatine kinase, serum glutamic oxaloacetic transaminase and serum lactic dehydrogenase were determined in all patients every 6 hours for 3 consecutive days. These determinations were obligatory in patients with chest pain of long duration and had to be less than twice the upper limit of the normal value 6 hours after the last attack of prolonged chest pain. 


\section{Coronary Arteriography and Left Ventriculography}

Coronary angiography was first performed within a median period of 9 hours (range 2 to 69) after the last attack of chest pain. In 40 patients it was repeated 1 day later (mean 25 hours); in one patient who developed bleeding, the restudy was carried out after 8 days.

The angina-producing artery was identified with the following criteria. In 17 patients with significant single vessel coronary disease, this vessel was considered to be the ischemia-related artery. In 22 patients with multivessel disease, the angina-producing artery was designated by the severity of the stenosis, aided by the location of ischemic ST-T segment changes during pain at rest (11 patients) or after pain (11 patients). In eight of the former and in six of the latter patients with multivessel disease, the ischemia-producing lesion corresponded with a hypokinetic left ventricular wall segment, illustrating the hemodynamic significance of the coronary obstruction.

One patient had "distant ischemia". After thrombolytic therapy, perfusion of the less severely diseased circumflex coronary artery improved and led to better retrograde filling of the occluded left anterior descending coronary artery. In this patient, the left circumflex coronary artery, which supplied the collateral vessels, was selected as the artery of interest. In one patient with a normal ECG and two vessel disease, we could not prospectively identify the ischemia-related artery. After intracoronary infusion of streptokinase, one vessel showed a significant decrease in lesion severity and was designated retrospectively the angina-producing artery.

The stenosis in the ischemia-related coronary artery was independently judged by three experienced angiographers and subjectively graded according to a modified method of the European Cooperative Study Group into one of the following categories: $0=$ normal vessel; $1=$ mild stenosis of $<50 \%$ of the vessel diameter; $2 \mathrm{a}=\bmod$ erate stenosis $\geq 50 \%$ but $<70 \%$; $2 \mathrm{~b}=$ moderate stenosis $\geq 70 \%$ but $<90 \% ; 3=$ severe stenosis $\geq 90 \%$ and complete filling of the distal vessel within three cardiac cycles not through collateral vessels; $4=$ subtotal occlusion without distal filling within three cardiac cycles; and $5=$ total occlusion with or without collateral filling (11).

Coronary artery dimensions were also assessed quantitatively by means of previously validated and described (24) computer-based cardiovascular angiography analysis system (CAAS) using high resolution digital subtraction images. This semiautomatic system has a highly reliable and reproducible edge detection algorhythm, which can assess the stenosis diameter (SEM for short-term repeat measurements of the obstructive diameter being $0.34 \mathrm{~mm}$ ). Area stenosis was calculated with videodensitometry. The profile across the vessel image was measured at the point of greatest narrowing and compared with that of the normal segment, thereby enabling calculation of the area stenosis as a function of luminal area. This is independent of its cross-sectional shape.

Qualitative techniques utilizing vessel magnification $(\times 2)$ were performed to identify intracoronary thrombosis $(25,26)$. Thrombosis was considered to be likely if a total occlusion of the coronary artery had irregular convex margins or if a nontotal occlusion showed irregular shaggy margins or an eccentric stenosis in the form of a convex intraluminal obstruction.

Collateral vessels were considered present if there was visualization of the artery differently from anterograde flow after injection of the contrast medium into another 
artery or into a proximal segment of the same artery that "joined" the obstructed dis" tal segment.

In 38 of the 41 patients, abnormalities in left ventricular wall motion were judged at the first cardiac catheterization serving to identify the angina-producing artery in the $30^{\circ}$ right anterior oblique and the 600 left anterior oblique views, and calcullated according to a modified method of Ingels et al (27). From these projections, the left ventricular silhouette was divided into several segments (anterobasal, anteroseptal, anterolateral, apical, posterobasal, diaphragmatic and posterolateral). In the remaining three patients, the left ventriculogram was not performed or of poor quality.

\section{Thrombolytic Agent and Heparin Administration}

After baseline angiography, the thrombolytic agent was administered. In the first part of the study, intracoronary streptokinase was infused at a rate of $6,000 \mathrm{U} / \mathrm{min}$. The total dose given was $250,000 \mathrm{IU}$. All these patients also received $100 \mathrm{mg}$ of prednisolone intravenously. In the second part of the study, intravenous single-chain recombinant tissue-type plasminogen activator ( $\mathrm{rt}-\mathrm{PA}$ ) was administered in the coronary care unit immediately after completion of baseline angiography. Ten $\mathrm{mg}$ was given as an intravenous bolus injection, followed by an intravenous infusion of $50 \mathrm{mg}$ in the first hour and $20 \mathrm{mg}$ in both the second and the third hour.

At the start of the first catheterization, all patients received heparin by an intraarterilal bolus injection of $1 \mathrm{mg} / \mathrm{kg}$ body weight. In the patients treated with streptokinase, heparin was only given after thrombolytic therapy if the plasma fibrinogen concentration (measured every 3 to 4 hours) had returned to values of $\geq 0.5 \mathrm{~g} /$ liter. In the study group treated with rt-PA, heparin was continued intravenously after thrombolytic therapy until the repeat angiography. The dosage of heparin was titrated depending on laboratory values measured every 3 to 4 hours. The aim of the titration was a prothrombine time of two to three times the upper limit of normal.

\section{Treatment Regimen}

Medical management consisted of therapeutic doses of a beta-adrenergic blocking agent (Lopresor), a nitrate (Mono-cedocard) and a calcium channel blocker (Tildiem) given when indicated. Antiplatelet drugs (aspirin, dipyridamole) were added after the second cardiac catheterization.

\section{Follow-up}

All patients who received thrombolytic therapy were followed-up for $\geq 3$ months after admission. The incidence of persistent unstable angina pectoris, myocardial infarction, death, coronary bypass graft surgery as well as coronary angioplasty was recorded.

\section{RESULTS}

\section{Patient Characteristics}

For the 41 patients receiving thrombolytic therapy, data on age, gender, previous his-

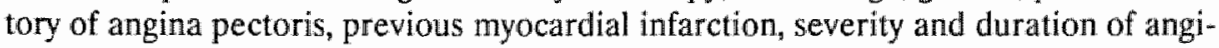


Table I. Clinical Characteristics of the 41 Patients on Entry to the Stuidy

\begin{tabular}{|c|c|c|c|}
\hline & SK & $\mathrm{r} \cdot \mathrm{PA}$ & Total \\
\hline No of patients & 21 & 20 & 41 \\
\hline Age $(\mathrm{yr})$ (mean $\pm \mathrm{SD}$ ) & $58=9$ & $58 \pm 6$ & $58 \pm 7$ \\
\hline No. of men & 17 & 16 & 33 \\
\hline Previous angina ( $>6$ waeks) & 8 & 7 & 15 \\
\hline Previous myocardial infarction & 3 & 6 & 9 \\
\hline \multicolumn{4}{|l|}{$\begin{array}{l}\text { Duration of unstable angina on entry } \\
\text { (diays) }\end{array}$} \\
\hline Mean $\pm S D$ & $7 \pm 6$ & $8 \pm 11$ & $8 \pm 9$ \\
\hline Median & 4 & 4 & 4 \\
\hline \multicolumn{4}{|l|}{ Severity of angina on entry } \\
\hline Class III & 5 & 6 & 11 \\
\hline Class IV, previous angina & 6 & 4 & 10 \\
\hline Class IV, angina of mew onset & 10 & 10 & 20 \\
\hline $\begin{array}{l}\text { Last attack of angina of long } \\
\text { duration }(>20 \mathrm{~min})\end{array}$ & 9 & 12 & 21 \\
\hline \multicolumn{4}{|l|}{ Creatine kinase } \\
\hline Normal & 19 & 17 & 36 \\
\hline $\begin{array}{l}\text { Abnormal ( } \| \times 102 \times \text { upper limit of } \\
\text { normal) }\end{array}$ & 2 & 3 & $s$ \\
\hline
\end{tabular}

ri-PA $=$ recambinant tissue-4ype plasminogen activator; $S K=$ sireptokjmase.

Table 2. Results of Baseline Coronary Angiographic and Left Ventriculographic Characteristics in the 41 Patients

\begin{tabular}{lccc}
\hline & SK & rt-PA & Total \\
\hline No. of patients & 21 & 20 & 41 \\
No. of diseased vessels & 11 & 6 & 17 \\
One & 8 & 7 & 15 \\
Two & 2 & 7 & 9 \\
Three & & & \\
Ischemia-related vesisel & 4 & 5 & 9 \\
RCA & 12 & 8 & 20 \\
LAD & 5 & 7 & 12 \\
LCX & 9 & 4 & 13 \\
Total obstruction & 7 & 8 & 15 \\
Thrombus in monoccluded wessels (28 patients) & 12 & 8 & 20 \\
Collateral vessels & 14 & 14 & 28 \\
Ischemia-retated abnormal wall motion & & & \\
(38 patients)
\end{tabular}

$\mathrm{LAD}=$ left anterior descending coronary artery; $\mathrm{LCX}=$ left circumflex coronary antery; $\mathrm{RCA}=$ right coronary artery; other abbreviations as in Table 1. 
nal complaints and enzyme changes before catheterization are given in Table 1. Fifteen patients had a prior history of stable angina, half had rest angina of new onset and 21 patients experienced episodes of chest pain of long duration.

\section{Angiographic Findings}

Table 2 gives information on the incidence of single, double and triple disease and the location and severity of the coronary lesion thought to be responsible for the unstable angina and the ECG abnormalities. Twelve of the 13 patients with a completely occluded vessel and 5 of the 9 patients with a severely narrowed vessel and sluggish anterograde flow had collateral circulation. At the second cardiac catheterization, these collateral vessels were visible in only 11 patients. Angiographic findings suggestive of intracoronary thrombus formation were present in 28 of the 41 ischemia-related vessels before thrombolytic therapy. At the second angiographic study, these findings were still present in 16 patients. The baseline contrast left ventriculogram revealed localized regions of abnormal wall motion during systole in 28 of 38 patients.

\section{Complications}

We observed a low complication rate in our patients with unstable angina. Although many patients had oozing at puncture sites and a decrease in hemoglobin level (mean $0.3 \mathrm{mmol} / \mathrm{liter}$ ), only one patient had bleeding at that site accompanied by retroperitoneal leakage requiring blood transfusion. Ventricular fibrillation occurred once in a patient and was promptly and successfully treated by external electrical countershock.

\section{Effect of Thrombolytic Therapy on Coronary Angiographic Findings}

Figure 1 demonstrates the subjective analysis and Table 3 the quantitative analysis of the coronary angiographic findings before and after thrombolysis. Figure 1 shows that the effect of thrombolytic therapy was most marked in occluded or severely narrowed vessels. This was confirmed by the quantitative analysis in which a marked improvement was found in the vessels narrowed $\geq 90 \%$ stenosis and no improvement was detected in vessels with $<90 \%$ stenosis. Table 3 indicates a $16 \%$ reduction $(\mathrm{p}<0.05$, paired $t$ test) of diameter stenosis in all patients and a $6 \%$ reduction $(\mathrm{p}<0.01$, paired $t$ test) of area stenosis in 30 of the 41 patients. In 11 patients with an extensively diseased ischemia-related vessel, it was not possible to derive a reliable measurement of area stenosis.

\section{Coronary Stenosis Severity and Clinical Characteristics}

Table 4 compares the coronary artery diameter narrowing before thrombolysis (as assessed by subjective analysis) and the clinical characteristics of the patient at the last attack of chest pain. The 10 patients with the most severely narrowed vessels (category 4 or 5) seemed to have a more frequent history of previously stable angina compared with the 5 patients with only moderate stenosis. No relation was found between the severity of coronary stenosis and the duration and severity of angina.

In the 22 patients showing a reduction in the acute coronary artery diameter narrowing (according to subjective analysis), we attempted to correlate this improvement with the clinical characteristics at entry into the study and the coronary angiographic find- 


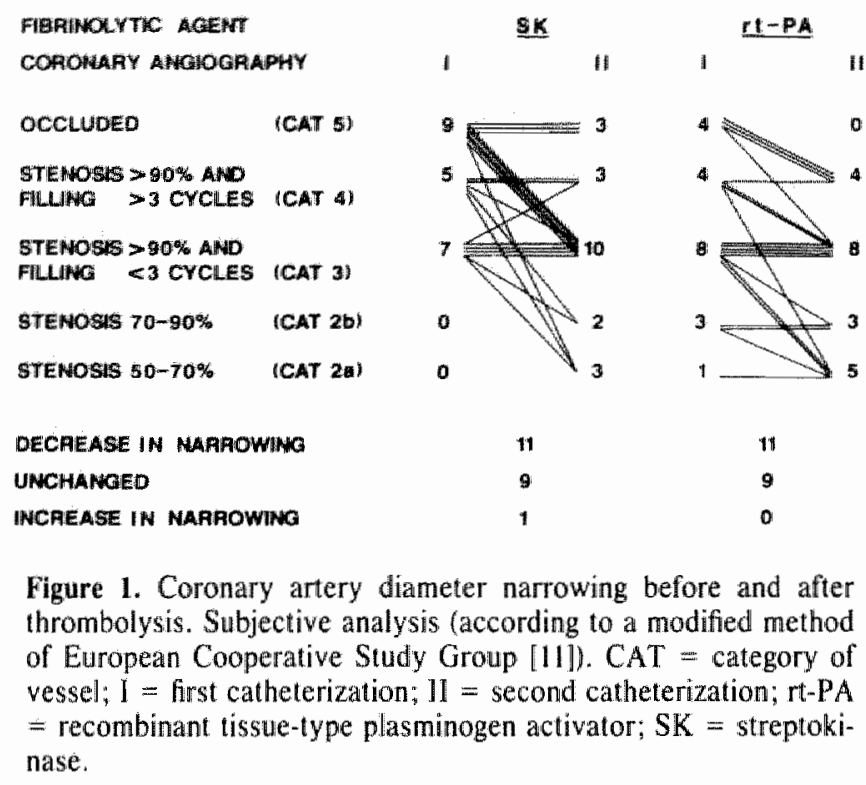

ings before thrombolysis. Except for a greater incidence of a complete or subtotal vessel occlusion, no clinical characteristics or remaining angiographic findings were different from those of the total study group.

Otherwise, improvement in coronary artery diameter narrowing did not result in improvement in functional class or a lower incidence of coronary bypass surgery or angioplasty.

We also attempted to correlate the improvement in functional class after thrombolysis and during hospitalization with clinical and angiographic variables in 26 patients. Except for a somewhat shorter mean duration of unstable angina ( 5 versus 8 days in the

Table 3. Coronary Artery Diameter Narrowing Before and After Thrombolysis: Quantitative Analysis (by CAAS)

\begin{tabular}{|c|c|c|c|c|}
\hline & \multicolumn{2}{|c|}{ Streptokinase } & \multicolumn{2}{|c|}{$\mathrm{rt}-\mathrm{PA}$} \\
\hline & 1 & $\|$ & I & II \\
\hline No. of patients analyzed & \multicolumn{2}{|c|}{21} & \multicolumn{2}{|c|}{20} \\
\hline $\begin{array}{l}\text { Diameter stenosis ( } \% \text { ) } \\
\text { (mean } \pm \text { SD) }\end{array}$ & $77 \pm 21$ & $67 \pm 20$ & $65 \pm 22$ & $51 \pm 19$ \\
\hline No. of patients analyzed & \multicolumn{2}{|c|}{17} & \multicolumn{2}{|c|}{13} \\
\hline $\begin{array}{c}\text { Area stenosis }(\%) \\
\text { (mean } \pm \text { SD })\end{array}$ & $92 \pm 9$ & $88 \pm 11$ & $93 \pm 9$ & $85 \pm 15$ \\
\hline
\end{tabular}

CAAS = Cardiovascular Angiography Analysis System; $1=$ first cardiac catheterization; II = second cardiac catheterization. 
Table 4. Coronary Artery Diameter Narrowing Before Thrombolysis (assessed by subjective analysis): Clinical Characteristics of 41 Patients at the Last Episode of Chest Pain, Peak Creatine Kinase Value and Collateral Vessels at the First Cardiac Catheterization

\begin{tabular}{lcc}
\hline & \multicolumn{2}{c}{ Category of Vessel } \\
\cline { 2 - 3 } & $4+5$ & $2+3$ \\
\hline No. of patients & 22 & 19 \\
Previously stable angina pectoris & 10 & 5 \\
Duration of unstable angina (days) & $7 \pm 8$ & $8 \pm 10$ \\
Mean \pm SD & 4 & 3 \\
Median & & \\
Severity of last attack of angina & 6 & 5 \\
Class III & 16 & 14 \\
Class IV & & \\
Time interval between last attack of & $21 \pm 19$ & $17 \pm 18$ \\
angina and first catheterization (h) & 13 & 10 \\
Mean \pm SD & & 1 \\
Median & 3 & 2 \\
Peak creatine kinase & 3 & 3 \\
I $\times$ to $2 \times$ upper limit of normal & 17 & \\
$>2 \times$ upper limil of normal & & \\
Collateral vessels present &
\end{tabular}

total study group), none of the remaining clinical characteristics or angiographic findings were different from those of the total study group. In addition, improvement in functional class was not based on a decrease in the severity of coronary artery stenosis (Table 5).

\section{Follow-up}

Myocardial infarction: Follow-up data concerning the incidence of myocardial infarction, coronary bypass graft surgery or coronary angioplasty and functional class after treament can be summarized as follows. Before or during thrombolytic treatment, nine patients had a small myocardial infarction. During hospitalization, an additional four

Table 5. Reduction in Coronary Artery Diameter Narrowing After Thrombolysis (assessed by subjectiwe analysis):

Improvement in Functional Class, Incidence of Coronary Bypass

Surgery or Coronary Angioplasty at Discharge From the Clinic

\begin{tabular}{lccc} 
& & \multicolumn{2}{c}{ Cononary Antery Anatomy } \\
\cline { 2 - 4 } & No. of Patients & Improved & Not Improved \\
\hline Angina class I, II & 26 & 14 & 12 \\
CABG-PTCA & 14 & 8 & 6 \\
\hline
\end{tabular}

$\mathrm{CABG}=$ coronary artery bypass graft: PTCA = percutaneous transluminal coronary angioplasty. 
patients developed a small myocardial infarction on an average of 6 days after entry in the study.

The mean duration of unstable angina in the group with infarction before or during thrombolysis was shorter than that in the total study group ( 4 versus 8 days). In all these patients the total duration of the last attack of chest pain was $>45$ minutes (mean 130 ), but there were no ECG signs of a new developing myocardial infarction on entry into the study. Five had relief but not complete disappearance of pain within 40 minutes after beginning treatment in the clinic.

Six of the nine patients in the group with infarction before or during trombolysis and none of the four patients with infarction "after" thrombolysis showed no or only sluggish anterograde flow in the ischemia-related vessel at the first cardiac catheterization. According to the baseline angiogram, 8 of the 13 patients did not have collateral vessels to protect the jeopardized myocardial tissue.

The highest mean creatine kinase values in the 13 patients with myocardial infarction "before or during" versus after thrombolysis were 2.2 and 3 times, the upper limit of normal, respectively. Only one of the nine patients with infarction "before or during" thrombolytic therapy and two of the four with infarction after this treatment showed a small $\mathrm{Q}$ wave and some $\mathrm{R}$ wave loss on the ECG at discharge. In eight patients, the QRS complex did not change.

Persisting or recurring angina: Eight of the 21 patients treated with streptokinase and 7 of the 20 patients receiving rt-PA continued to have anginal pain (class III and IV) in the hospital. Fourteen patients were treated during their hospital stay by coronary bypass graft surgery (10 patients) or coronary angioplasty (4 patients). After discharge, an additional number of patients had recurrent angina, leading to bypass surgery in three and angioplasty in two.

At the end of the 3 month follow-up, 31 patients were in functional class $I$ and 8 patients in class II. No patient died or developed myocardial infarction after discharge from the clinic.

\section{$\overline{\text { DISCUSSION }}$}

The term "unstable angina" has been applied to a heterogeneous group of patients with a variety of clinical presentations that have in common a picture of presumed acute myocardial ischemia and are characterized by an unpredictable blebleblebleclinical course. Increasingly severe obstructive coronary stenosis, coronary spasm (28) and platelet aggregates, alone or in combination, have been implicated as causes of unstable angina pectoris.

\section{Coronary Artery Distribution and Severity of Stenosiis}

Patients with unstable angina have a higher incidence of left main coronary artery disease and perhaps of proximal left anterior descending coronary artery disease than do patients with stable angina pectoris (29).

In our study, 20 of the 41 patients had a diseased left anterior descending coronary artery; none had sigificant left main stem disease as the "culprit" artery. 
Coronary occlusion is frequently found in patients during the evolution of $\mathrm{Q}$ wave myocardial infarction (1) and less often in early non- $\mathrm{Q}$ wave myocardial infarction ( 30 ). Among our patients with unstable angina pectoris, $50 \%$ demonstrated a complete or almost totally occluded ischemia-related vessel, a finding in agreement with the study of Plotnick et al (31)... In the streptokinase-treated group, this finding was more prevalent than in the rt-PA-treated group. A possible explanation is that in the streptokinase study group, the results were retrospectively analyzed and the vessels had to be "sultable" for treatment with a fibrinolytic agent. The data from another study (30) suggest that the rate of occlusion increases with the duration of the time interval between the last attack of chest pain and baseline angiography. In the streptokinase-treated group, this interval was twice that of the rt-PA study group (mean 25 versus 13 hours). This finding is another possible reason for the difference in the incidence of a complete (or near totally) occluded angina-producing vessel in both treatment groups.

\section{Role of Thrombus}

The incidence and the significance of thrombus formation in unstable angina are less well defined. Suggestive evidence for thrombus formation in preinfarction angina includes studies (32-34) indicating that one-third of patients with an impending myocardial infarction develop transmural infarction over a short interval. Also, pathologic anatomic studies (35-37) on coronary thrombosis in transmural infarction have demonstrated a laminar appearance of the thrombus with layers of varying age. These observations are consistent with several angiographic observations (16-22) of partially occluding thrombi seen in these patients. Furthermore, observations (23) using coronary angioscopy during coronary bypass surgery suggest that unstable angina refractory to medical treatment can be caused by pathologic processes in the intima. The therapeutic effect of antiplatelet aggregation medication (38-39) and the results of physiochemical studies (40-44) in patients with unstable angina support the important role of intracoronary thrombosis.

Using our previously described criteria, we could identify angiographic evidence of intracoronary thrombus formation in $28(68 \%)$ of 41 ischemia-related vessels before infusion of streptokinase or rt-PA. Sixteen patients continued to have angiographic evidence of thrombosis at the second angiographic study. If this observation of a "high" prevalence of thrombus after thrombolytic therapy is correct, it might explain the high incidence of patients who remained refractory to medical treatment. Irregular shaggy margins or eccentric stenosis may be caused, however, not onlly by thrombosis, but also by ulceration of the intimal plaque.

\section{Collateral Flow}

Development of collateral vessels plays an important role in myocardial oxygen supply of the jeopardized myocardium and the prevention of a large myocardial infarct. The presence of collateral flow correlates with the extent and severity of cononary artery disease $(31,45,46)$. In the earlier mentioned study of Plotnick et al. (31), collateral vessels were present in 91 of 110 totally obstructed major coronary arteries and in 15 of 69 vessels with near total ( 90 to $99 \%$ ) occlusion. 
Collateral vessels were visualized in our study in 12 of 13 totally occluded coronary arteries, in 5 of 9 severely narrowed arteries with a sluggish anterograde flow and in only 3 of 15 severely narrowed vessels with anterograde distal filling within three cardiac cycles. At the second coronary angiography, the incidence of these collateral vessels was lower (namely, 11 patients), indicating an improved or reestablished anterograde coronary flow and a less threatened myocardium.

\section{Thrombolysis and Angiographic Changes}

After streptokinase or rt-PA administration, 10 of 13 occluded coronary vessels showed recanalization, 12 vessells had a decrease in the severity of stenosis and 1 vessel had an increase in diameter narrowing. Therefore, angiographic evidence of thrombolysis was demonstrated after the second angiographic study in 22 of the 41 infusions with a thrombolytic agent or in 19 of 28 vessels with a suggestion of intracoronary thrombosis during baseline angiography. The decrease in the incidence of complete or near total occlusion after thrombolytic therapy suggests that the observed changes were a result of thrombolytic therapy and not of spontaneous resolution.

\section{Previous Studies on Thrombolysis in Unstable Angina}

Previous clinical studies using streptokinase in unstable angina demonstrated a range from minor to major angiographic changes in native and bypass vessels. Rentrop et al. (2) studied five patients with prolonged angina at rest and noted no change in "subtotal" lesions after the intracoronary administration of $128,000 \mathrm{IU}( \pm 36,000)$ of streptokinase. This is in contrast with our data, in which the effect of thrombolytic therapy was most marked in occluded or severely narrowed vessels. Ventrovec et al. (18) administered 100,000 to 350,000 IU of intracoronary streptokinase in 12 patients with repeated prolonged episodes of angina at rest of less than 2 weeks' duration. They reported angiographic "success" after 10 of the 12 infusions, although the majority of patients had minor changes. In nine patients with prolonged or frequent recurrent angina at rest, Mandelkorn et al. (19) administered 240,000 IU of intracoronary streptokinase, which resulted in angiographic "success" in four patients. The differences in outcome between these studies are probably related to differences in patient selection, timing of the intervention in relation to episodes of chest pain and total dosage of the thrombolytic agent.

In the recent study by Ambrose et al. (47) of 37 catheterized patients with either an acute episode of unstable angina (29 patients) or a recent non-Q wave infarction ( 8 patients) and in whom a less than $100 \%$ occluded ischemia-producing artery could be identified, no significant changes in any quantitative or qualitative variable were found after thrombolytic therapy. The inclusion of recent non-Q wave infarction and the exclusion of totally occluded vessels (showing the most marked beneficial effect in our study) undoubtedly explains the difference in total outcome between their study and ours. Gold et al. (48) studied 23 patients with unstable angina at rest and transient ST segment deviations of at least $1 \mathrm{~mm} ; 38$ hours ( \pm 19 ) after infusion and a monitoring period of 2 to 28 hours, they demonstrated a subocclusive thrombus in 8 of 11 patients receiving placebo, but in none of 12 patients treated with rt-PA. 


\section{Subjective versus Quantitative Measurement of Coronary Stenosis}

In our study of unstable angina, improvement in the severity of coronary artery stenosis was demonstrated by both subjective and quantitative analysis. We do not have an explanation why the effect was most marked in the severely stenotic vessels and (similar to the study of Ambrose et al. (47)) not in vessels having < $<0 \%$ diameter narrowing. In this subgroup of patients, spasm can play a (more important) role (28).

The explanation for the difference in results of the subjective and quantitative measurements of coronary artery narrowing has been provided by Mc Mahon et al. (49). The subjectively graded minimal reduction in luminal diameter is comparable with the quantitatively assessed area stenosis (in patients with new onset of refractory rest angina and ischemic ST-T changes). We calculated only the diameter stenosis and the areas stenosis for quantitative measurements because we wanted to quantify the subjectively graded minimal luminal diameter reduction, the variables we used for correlation assessments. Also, the percent stenosis determined by videodensitometric analysis correlated wel. with the percent reduction in cross-sectional area as measured postmortem by histologic planimetry $(r=0.97)(50)$.

\section{Incidence of Myocardial Infarction}

Thirteen of the 41 patients showed an increase (mean 2.4-fold) in serum creatine kinase during their hospitalization. "This incidence is in accord with previously reported data (32-34) that in one-third of patients with an impending myocardial infarction transmural infarction occurs over a short interval. The type of infarction in our study was different, however; only three patients showed the development of small electrocardiographic $Q$ waves. In the absence of a placebo-controlled study, it is as yet unknown if myocardial damage is less extensive after thrombolytic therapy.

\section{Clinical Events}

The effect of thrombolytic therapy on anginal symptoms in this study group is unclear. Twenty-six of 41 patients had a decline in symptoms during their 10 days in hospital. The improvement in functional class did not correlate with the reduction in the severity of coronary artery stenosis. Many patients had only temporary clinical benefit and experienced recurrent anginal pain, leading to coronary angioplasty in 6 patients and bypass surgery in 13 during the 3 month follow-up period. These events were also not related to the effect of thrombolytic therapy on coronary artery diameter narrowing or on the postthrombolytic antithrombotic regimen which, although not uniform, was nevertheless adlequate. Because changes in pressure vary as the fourth power of diameter stenosis ( 51 ), minimal (nondetectable) changes in coronary diameter may theoretically cause a decrease or a further increase in episodes of ischemia in unstable angina. In the study of Gold et al. (48), unstable angina persisted after completion of the infusion in 6 of 11 patients receiving placebo (follow-up $7 \pm 5$ days) and in only 1 of 12 patients receiving rt-PA (follow-up $8 \pm 4$ days).

Definite conclusions regarding the clinical response to thrombolysis in patients with unstable angina are not possible because of the small number of patients, the unknown natural course of the coronary artery anatomy (spontaneous resolution by means of endogenous thrombolysis) and the relatively short follow-up periods. Furthermore, 
several of these patients received a variety of additional pharmacologic agents, including heparin and aspirin $(38,39,52)$, which may have influenced the efficacy of thrombolytic therapy.

\section{Prognosis}

A prognostic elassification of patients with unstable angina is currently not available but is urgently needed because information about prognosis is essential to determine the aggressiveness of diagnostic and therapeutic interventions. Pain characteristics, response to conventional medical therapy, objective evidence of the extent of the ischemic area, previous myocardial infarction, coronary anatomy and left ventricular function are all factors likely to influence this prognostic classification. Furthermore, the risk and benefit of an aggressive approach with thrombolytic therapy have to be determined.

\section{$\overline{\text { CONCLUSIONS }}$}

The syndrome of unstable angina appears to be frequently associated with intracoronary thrombosis, as evidenced by angiographic changes seen before and after thrombolytic therapy. The data from this study do not allow us to make a complete assessment of the clinical efficacy of such therapy. Placebo-controlled randomized studies are required to determine the true value of thrombolytic therapy in the management of unstable angina pectoris, to assess the risk/benefit ratio of this type of therapy and to identify subgroups of patients who would receive the greatest benefit.

\section{REFERENCES}

1. De Wood MA, Spores J, Notske R, et al:

Prevalence of total coronary occlusion during the early hours of transmural myocardiall infarction. N. Engl. J. Med. 1980; 303: 897-902.

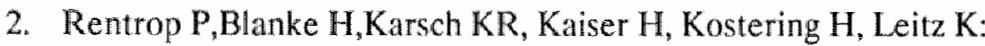

Selective intracoronary thrombolysis in acute myocardial infarction and unstable angina pectoris. Circulation 1981; 63:307-317.

3. Anderson JL, Marshall HW, Bray BE, et al:

A randomized trial of intracoronary streptokinase in the treatment of acute myocardial infarction. N. Engl. J. Med. 1983; 308: 1312-1318.

4. Kennedy JW, Ritchie JL, Davis KB, Fritz JK:

Western Washington randomized trial of intracoronary streptokinase in acute myocardial infarction. N. Engl. J. Med. 1983; 309: 1477-1482. 
5. Rentrop KP, Feit F, Blanke H, et al:

Effects of intracoronary streptokinase and intracoronary nitroglycerin infusion on coronary angiographic patterns and mortality in patients with acute myocardial infarction. N. Engl. J. Med. 1984; 311: 1457-1463.

6. Simoons ML, Serruys PW, Brand M vd, et al:

Improved survival after early thrombolysis in acute myocardial infarction: A randomized trial conducted by the I.C.I.N. Lancet $1985 ; 2: 578-582$.

7. Gruppo Italiano per lo Studio della Streptochinasi nell'Infarto miocardico (GISSI): Effectiveness of intravenous thrombolytic treatment in acute myocardial infarction. Lancet 1986; 1: 397-401.

8. The I.S.A.M. Study Group:

A prospective trial of intravenous streptokinase in acute myocardial infarction (I.S.A.M.) N. Engl. J. Med. 1986; 314: 1465-1471.

9. Isis Steering Committee:

Intravenous streptokinase given within 0-4 hours of onset of myocardial infarction reduced mortality in ISIS-2. Lancet 1987; 1: 502.

10. Vermeer F, Simoons ML, de Zwaan $C_{\text {, }}$ et al:

Cost benefit analysis of early thrombolytic therapy with intracoronary streptokinase. Br. Heart J.; in press.

11. TIMI Study Group:

The thrombolysis in myocardial infarction (TIMI) trial : phase I findings. N. Engl. J. Med. 1985; 312: 932-936.

12. Verstraete $\mathrm{M}$, Bory $\mathrm{M}$, Collen $\mathrm{D}$, et al:

Randomised trial of intravenous recombinant tissue type plasminogen activator versus intravenous streptokinase in acute myocardial infarction. Lancet 1985; 1: 842-847.

13. Been M, De Bono DP, Muir AL, et al:

Clinical effects and kinetic properties of intravenous APSAC * anisoylated plasminogen - streptokinase activator complex (BRL 26921) in acute myocardial infarction. Intern. J. Cardiol. 1986; 11: 53-61.

14. Kaspar W, Meinertz T, Wollschlager H, et al*

Coronary thrombolysis during acute myocardial infarction by intravenous BRL 26921, a new anisoylated plasminogen - streptokinase activator complex. Am. J. Cardiol. 1986; 58: 418-421. 
15. Werf $\mathrm{F}$ vd, Vanhaecke J, Geest $\mathrm{H}$ de, Verstraete M, Collen D:

Coronary thrombolysis with recombinant single-chain urokinase-type plasminogen activator in patients with acute myocardial infarction. Circulation 1986; 74 : 10661070.

16. Vetrovec GW, Cowley MJ, Overton H, Richardson DW:

Intracoronary thrombus in syndromes of unstable myocardial ischemia. Am. Heart J. 1981; 102: 1202-1208.

17. Holmes DR Jr, Hartzler GO, Smith HC, Fuster V:

Coronary artery thrombosis in patients with unstable angina. Br. Heart J. 1981; 45: 411-416.

18. Vetrovec GW, Leinbach RC, Gold HK, Cowley MJ:

Intracoronary thrombolysis in syndromes of unstable ischemia: angiographic and clinical results. Am. Heart J. 1982; 104: 946-952.

19. Mandelkorn JB, Wolf NM, Singh S, et al:

Intracoronary thrombus in nontransmural myocardial infarction and in unstable angina pectoris. Am. J. Cardiol. 1983; 52: 1-6.

20. Ambrose JA, Winters SL, Stern A, et al:

Angiographic morphology and the pathogenesis of unstable angina pectoris. J. Am. Coll. Cardiol. 1985; 5: 609-616.

21. Bresnahan DR, Davis JL, Holmes DR Jr, Smith HC:

Angiographic occurrence and clinical correlates of intraluminal coronary artery thrombus: role of unstable angina. J. Am. Coll. Cardiol. 1985; 6: 285-289.

22. Capone G, Wolf NM, Meyer B, Meister SG:

Frequency of intracoronary filling defects by angiography in angina pectoris at rest.

Am. J. Cardiol. 1985; 56: 403-406.

23. Sherman CT, Litvack F, Grundfest W, et al:

Coronary Angioscopy in patients with unstable angina pectoris. N. Engl. J. Med. 1986; 315: 913-919.

24. Reiber JHC, Serruys PW, Kooyman CJ, et al:

Assessment of short-, medium- and long-term variations in arterial dimensions from computer-assisted quantitation of coronary cineangiogram. Circulation 1985; $71: 280-288$.

25. Ambrose JA, Winters SL, Arora RR, et al:

Angiographic evolution of coronary artery morphology in unstable angina. J. Am. Coll. Cardiol. 1986; 7: 472-478. 
26. Wilson RF, Holida MD, White CW:

Quantitative angiographic morphology of coronary stenoses leading to myocardial infarction or unstable angina. Circulation 1986; 73: 286-293.

27. Ingels NB Jr, Daughters GT, Stinson EB, Alderman EL:

Evaluation of methods for quantitating left ventricular segmental wall motion in man using myocardial markers as a standard. Circulation 1980; 61: 966-972.

28. Oliva PB:

Unstable rest angina with ST-segment depression: Pathophysiologic considerations. Ann Intern Med. 1984; 100: 424-440.

29. Plotnick GD, Greene HL, Carliner NH, Becker LC, Fisher ML:

Clinical indicators of left main coronary artery disease in unstable angina. Ann. Intern. Med. 1979; 91: 149-153.

30. De Wood MA, Stifter WF, Simpson CS, et al:

Coronary arteriographic findings soon after non-Q-wave myocardial infarction. $N$. Engl. J. Med. 1986; 315: 417-423.

31. Plotnick GD, Fisher ML, Lerner B, Carliner NH, Peters RW, Becker LC:

Collateral circulation in patients with unstable angina. Chest 1982;82: 719-725.

32. Neill WA, Ritzmann LW, Selden R:

The pathophysiologic basis of acute coronary insufficiency: observations favoring the hypothesis of intermittent reversible coronary obstruction. Am. Heart J. 1977; 94: 439-444.

33. Neill WA, Whorton TP Jr, Fluri-Lundeen J, Cohen JS:

Acute coronary insufficiency - coronary occlusion after intermittent ischemic attacks. N. Engl. J. Med. 1980; 302: 1157-1162.

34. HINT Research Group:

Early treatment of unstable angina in the coronary care unit: A randomised, double blind, placebo-controlled comparison of recurrent ischaemia in patients treated with Nifedipine or Metoprolol or both. Br. Heart J. 1986; 56: 400-413.

35. Levin DC, Fallon JT:

Significance of the angiographic morphology of localized coronary stenoses: histopathologic correlations. Circulation 1982; 66: 316-320. 
36. Fak E:

Unstable angina with fatal outcome; dynamic coronary thrombosis leading to infarction and/or sudden death: autopsy evidence of recurrent mural thrombosis with peripheral embolization culminating in total vascular occlusion. Circulation 1985; 71: 699-708.

37. Feldman RL:

Coronary thrombosis, coronary spasm and speculation on the link between unstable angina and acute myocardial infarction. Am. J. Card. 1987; 59: 1187-1190.

38. Lewis HD, Davis JW, Archibald DA, et al:

Protective effect of aspirin against acute myocardial infarction and death in men with unstable angina. N. Engl. J. Med. 1983; 309: 396-403.

39. Cairns JA, Gent M, Singer J, et al:

Aspirin, Sulfinpyrazone, or both in unstable angina: results of a Canadian Multicenter Trial. N. Engl. J. Med. 1985; 313: 1369-1375.

40. Folts JD, Gallagher $K_{\text {, Rowe }} \mathrm{GG}$ :

Blood flow reductions in stenosed canine coronary arteries: vasospasm or platelet aggregation? Circulation $1982 ; 65: 248-255$.

41. Robertson RM, Robertson DM, Roberts LJ, et al:

Thromboxane $\mathrm{A} 2$ in vasotonic angina pectoris: Evidence from direct measurements and inhibition trials. N. Engl. J. Med. 1981; 304: 998-1003.

42. Hirsch PD, Firth BG, Campbell WB, Dehmer GJ, Willerson JT, Hillis LD:

Effects of provocation on transcardiac thromboxane in patients with coronary artery disease. Am. J. Cardiol. 1983; 51: 727-733.

43. Buja LM, Willerson JT:

Pathophysiology of angina pectoris and acute ischemic heart disease. Cardiovasc. Rev. Reports 1983; 4: 1553-1562.

44. Fitzgerald DJ, Roy L, Catella F, FitzGerald GA:

Platelet activation in unstable coronary disease. N.Engl.J.Med. 1986; 315: 983-989.

45. Fuster V, Frye RL, Connolly DC, Danielson MA, Elveback, LR, Kurland LT:

Angiographic patterns early in the onset of the coronary syndromes. Br. Heart J. $1975 ; 37: 1250-1255$.

46. Gorlin R, Fuster V, Ambrose JA:

Anatomic-physiologic links between acute coronary syndromes. Circulation 1986; $74: 6-9$. 
47. Ambrose JA, Hjemdahl-Monsen C, Borrico S, et al:

Quantitative and qualitative effects of intracoronary streptokinase in unstable angina and non-Q-wave infarction. J. Am. Coll. Cardiol. 1987; 9: 1156-1165.

48 Gold HK, Johns JA, Leinbach RC, et al:

A randomized, blinded, placebo-controlled trial of recombinant human tissue-type plasminogen activator in patients with unstable angina pectoris. Circulation 1987; 75: 1192-1199.

49. Mc Mahon MM, Brown BG, Cukingnan R, et al:

Quantitative coronary angiography: Measurement of the "critical" stenosis in patients with unstable angina and single-vessel disease without collaterals. Circulation 1979; 60: 106-113.

50. Nichols AB, Gabrieli CFO, Fenoglio JJ, Esser PD:

Quantification of relative coronary arterial stenosis by cine videodensitometric. analysis of coronary arteriograms. Circulation 1984; 69: 512-522.

51. Gould KL:

Dynamic coronary stenosis Am. J. Cardiol. 1980; 45: 286-292.

52. Telford AM, Wilson C:

Trial of heparin versus atenolol in prevention of myocardial infarction in intermediate coronary syndrome. Lancet 1981; 1: 1225-1228. 



\title{
Clinical diagnoses in patients showing electrocardiographic changes as seen in patients with unstable angina and a critical narrowing of the proximal left anterior descending coronary artery.
}

\author{
Chris de Zwaan,MD, Emile C. Cheriex, MD, Hein JJ Wellens, MD.
}

Submitted for publication

\section{$\overline{\text { ABSTRACT }}$}

In 264 patients ECG changes were observed as found in patients with unstable angina and a critical narrowing in the proximal left anterior descending coronary artery. Thirty nine patients had no evidence for LAD coronary artery disease but a variety of findings ranging from cardiomyopathy, mitral valve disease, pulmonary embolism, rhythm or conduction abnormalities to no disease. Frequently careful evaluation of the history and physical examination leads to the correct diagnosis. Occassionally non-invasive and invasive tests are required.

\section{INTRODUCTION}

In 1982 our group described a typical electrocardiographic pattern in patients with unstable angina pointing to a critical stenosis in the proximal left anterior descending coronary artery (LAD) (1). Recently, we reported upon the findings in a larger group of these patients (2).

Both articles stress the value of the electrocardiogram in making the correct diagnosis. It is important to know how often and under what clinical circumstances similar ECG changes occur. The purpose of this study is to report upon the clinical diagnosis in patients showing or developing ST-T segment changes indistinguishable from those seen in proximal $\mathrm{LAD}$ stenosis.

\section{MATERIAL AND METHODS}

During the study period (1980 to 1988) 264 patients admitted to the Department of Cardiology of the Academic Hospital Maastricht showed or developed the ECG pattern shown in figure 1 , consisting of ST-T segment abnormalities in leads $V_{2}$ and $V_{3}$ in the presence of an obviously normal QRS complex. These changes consisted of an isoelectric or minimally ( $<1 \mathrm{~mm}$ ) elevated take off of the $\mathrm{ST}$ segment followed by a 


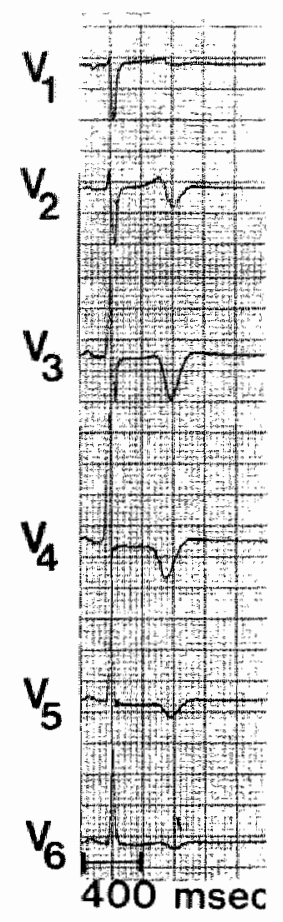

FIGURE 1: The ECG pattern found in the precordial leads in the patients discussed in the article.

concave or straight ST segment passing into a symmetrically inverted $\mathrm{T}$ wave. Frequently similar abnormalities were seen in leads $V_{4}$ and $V_{5}$. No limits were set for the exact depth of the T wave in the different leads to be admitted to the study. The abnormalities could be present persistently, intermittently or transiently during the admission to hospital and follow-up.

Patients showing only inverted $T$ waves, as seen during recovery of pericarditis, electrolyte abnormalities or following drug administration were excluded.

\section{Clinical diagnosis}

In all patients the clinical diagnosis was established after analysing the history, physical examination, laboratory tests, X-ray examination, echocardiogram and catheterization data. The investigations were done at the time of the described electrocardiographic abnormalities or shortly thereafter.

Almost all patients underwent cardiac catheterization with coronary angiography to evaluate the coronary artery anatomy. The degree of coronary artery narrowing was subjectively graded. Left (and sometimes right) ventricular wall motion was quantitatively calculated by way of the left and right anterior oblique projections of the contrast ventriculography (3) or was semi-quantitatively estimated by way of the M-mode and $2 \mathrm{D}$ echocardiogram (4). The systolic and diastolic wall motion were graded as normal or abnormat. 
Following clinical diagnosis patients were grouped in 5 categories. 1) Atherosclerotic coronary heart disease; 2) non-atherosclerotic coronary heart disease; 3 ) cardiac disease other than coronary artery disease; 4) rhythm and conduction disturbances "without" coronary artery disease; 5) "no cardiac disease".

\section{$\overline{\text { RESULTS }}$}

Table 1 lists the number of patients in the different diagnostic categories.

Patients in categories I and II had a history of ischemic chest pain and coronary artery disease on coronary angiography. One patient from category II deserves a more detailed description. This boy of 15 years old was admitted with complaints of anginal pain of acute onset. Echocardiography revealed a giant intrapericardial aneurysm of the left atrial appendage with abnormal systolic and diastolic motion of the anteroseptal region. At operation the aneurysm was found to be lying over the left anterior descending coronary artery. The aneurysm was removed. Cardiac catheterization was performed six weeks later and no coronary artery disease was found. Left ventricular wall motion had normalized. Compression of the LAD by the aneurysm was assumed to be the cause of the transient ECG and left ventricular wall motion changes.

The third category consisting of cardiac disease other than coronary artery disease was divided into 3 subgroups.

In the first subgroup 7 patients had hypertrophic cardiomyopathy. Four of them had hypertension, one was an athlete. The echocardiogram revealed in 6 patients generalized left ventricular hypertrophy, and in one case signs of obstructive cardiomyopathy.

One patient from the second subgroup, having mitral valve prolapse, showed on the left ventricular angiogram an abnormal contraction pattern of the mitral valve annulus and the basal portion of the left ventricle.

In 4 patients of the third subgroup having pulmonary disease no coronary angiography was performed. None suffered from anginal complaints. Two of them had a negative Thallium exercise test during follow-up.

Patients having chronic disease often showed persistent ST-T segment changes as compared to patients having acute injury or pressure/volume changes, where a transiently abnormal ECG was recorded.

In the fourth category one patient did not undergo left heart catheterization. That was a 23 year old man with intermittent pre-excitation who suffered palpitations since 11 years. The ST-T segment abnormalities were present when pre-excitation was absent. Following epicardial dissection of a right laterally located accessory pathway his complaints and abnormal ECG disappeared.

In the fifth category of "no cardiac disease" two patients had contusion of the brain. In the 13 year old boy autopsy was performed, which excluded coronary artery disease. The 5 patients with atypical chest pain had no abnormalities following extensive investigation. 


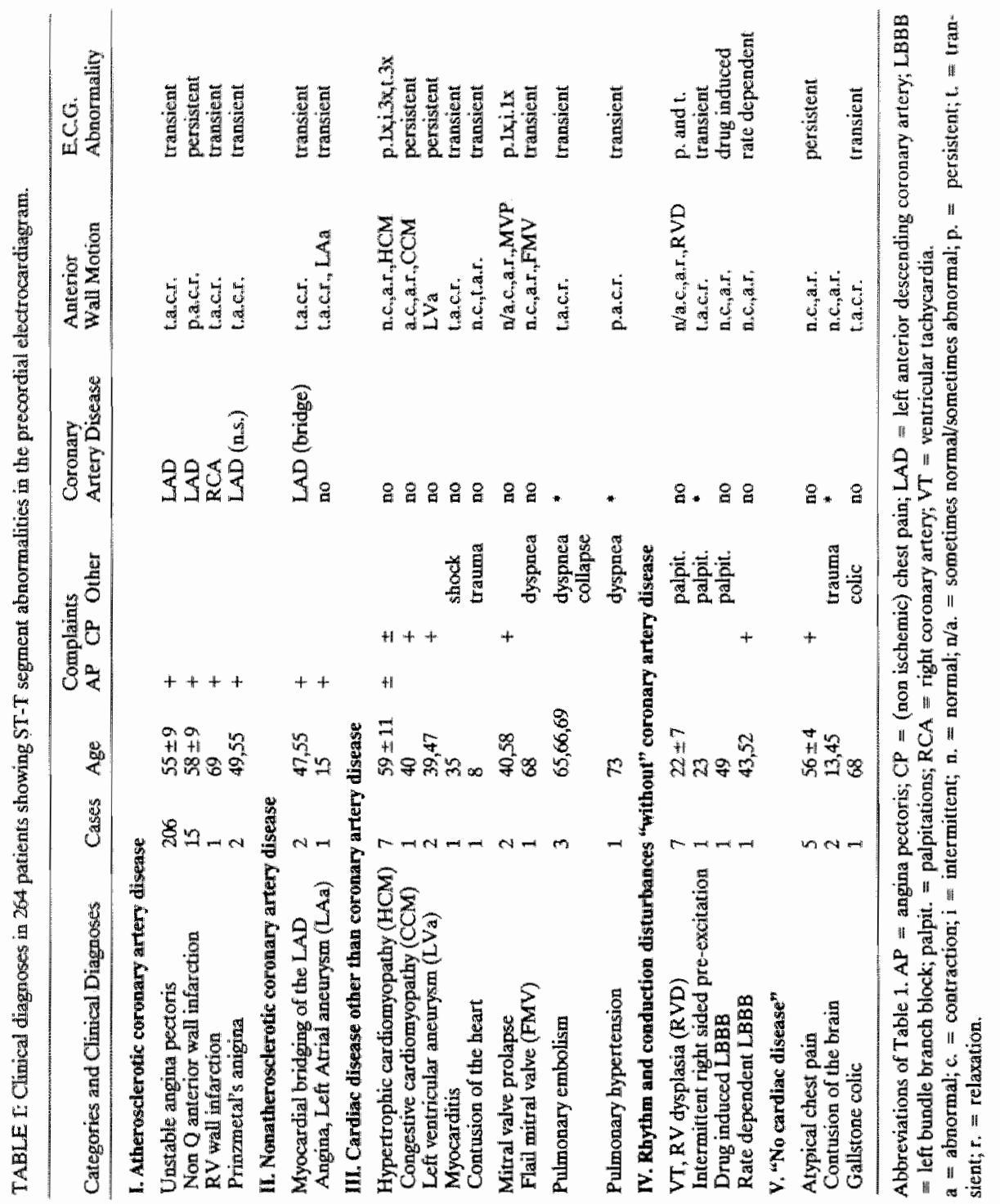




\section{$\overline{\text { DISCUSSION }}$}

Establishing the cause of an abnormality on the electrocardiogram is of obvious importance. Similar changes may result from different causes. In recent years we have called attention to a rather typical ECG pattern in patients with unstable angina pointing to severe narrowing in the proximal left anterior descending coronary artery $(1,2)$. To avoid making an incorrect diagnosis of such an electrocardiographic abnormality, we report here other conditions showing similar ECG changes. Most diagnoses listed in table 1 could be made by taking a history and doing a physical examination, illustrating that the correct interpretation of the described ECG pattern can usually be reached with that information.

The abnormal ST segment accompanied by an inverted T wave described in this article and illustrated in figure 1 were first reported in 1955 by Pruitt et al (5) in coronary artery disease and in cardiac disease other than coronary artery disease.

The mechanism of the ST-T segment changes is less well understood. Normally, in the absence of QRS changes, the precordial leads show $T$ wave positivety in leads $V_{2}$ to $V_{6}$. The $T$ wave may be positive or negative in lead $V_{1}$. In healthy children the transition from a negative to a positive $T$ wave may occur as far to the left as $V_{3}$. As pointed out by Wilson et al (6) the T wave configuration in the precordial leads of the normai heart is caused by the transmural pressure gradient which prolongs the duration of depolarization and repolarization in the subendocardial as compared to the subepicardial layer. Recently Franz et al (7) illustrated that a progressively later activation is associated with progressively earlier repolarization. The transmural gradient of repolarization suggests earlier repolarization in the epicardial layer.

Injury to the subendocardial layer may lead to further prolongation of excitation and repolarization of that area leading to a change in the terminal part of the ST segment and the $T$ wave.

Injury to the subendocardial tissue, reversible or persistent, is likely to play a role in the ST-T segment changes found in the first two categories of patients of table $\mathbb{1}$ having coronary artery disease.

In patients with unstable angina showing the described ST-T segment changes, angiography and echocardiography showed anterior wall motion abnormalities in systole and diastole, which disappeared following restoration of sufficient coronary bioodflow (4). This finding suggests temporary and reversible damage of at least the subendocardial layer. Damage in that area has been documented in patients dying of a non-Q anterior wall infarction (8). Subendocardial damage has also been reported in patients dying from intracranial disease (9-11).

In cardiomyopathy both structural changes in the ventricular wall and altered pressure volume relations may lead to ST-T segment changes. The type of overloading might induce a further prolongation of the excited state of the endocardium and thereby a change in sequence and direction of the ventricular repolarization.

Systolic and/or diastolic overload may also play a role in the ST-T segment changes seen in flail mitral valve, myocarditis, pulmonary disease and right ventricular infarction. 
In right ventricular injury the electrocardiographic anomaly can also be due to a (relative) suppression of electrical forces by simultaneous LV inferoposterior injury as occurring in the right ventricular and left infero-posterior infarction (12).

The ECG changes in mitral valve prolapse may relate to ischemia of papillary muscles and of the left ventricular bases because of increased tension on these structures by the prolapsing valve (13). An underlying cardiomyopathy has also been postulated (1.4).

An interesting group of patients are those showing the ST-T segment changes in relation to rhythm or conduction abnormalities. As pointed out by Rosenbaum et al (15) transient precordial $\mathrm{T}$ wave changes may accur following episodes of abnormal ventricular depolarization. In these cases the typical inverted $T$ wave develops in those leads where the abnormal ventricular activation originates. The first observations on this phenomenon were made in patients after pacing of the ventricle (16). The duration of these repolarization changes is related to the duration of abnormal ventricular excitation $(15,17)$.

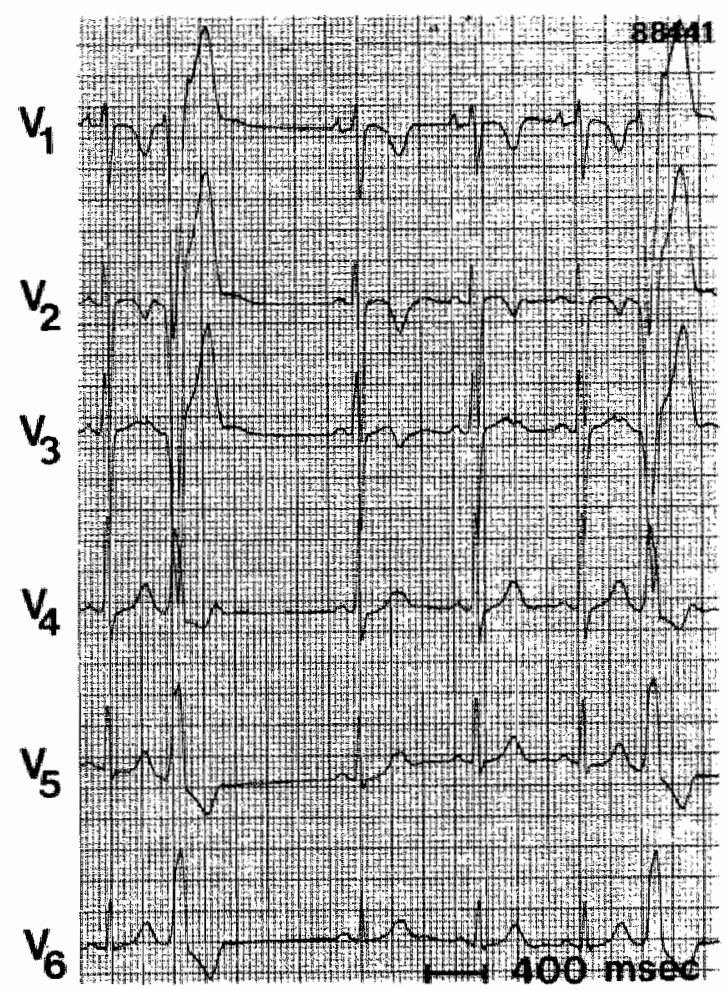

FIGURE 2: Example of the ECG pattern in the precordial leads in right ventricular dysplasia. The $T$ wave changes are most outspoken following the ventricular premature beat. 


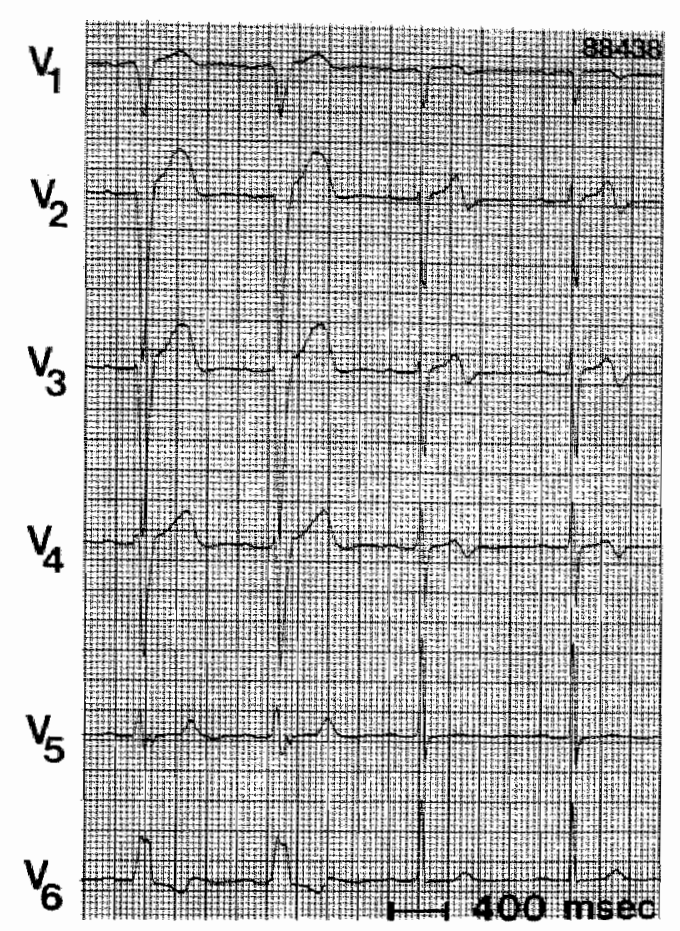

FIGURE 3: Example of the ST-T segment changes in the precordialleads following disappearance of rate dependent left bundle branch block.

In our patients $T$ wave negativity in the precordial leads was seen after right ventricular tachycardia (figure 2), intermittent left bundle branch block (figure 3) and intermittent conduction over a right sided accessory atrio-ventricular pathway. In right ventricular dysplasia we have seen in addition to transient $T$ wave negativity following an episode of ventricular tachycardia also persistent T wave negativity. Many of these patients have widespread right ventricular disease with marked dilatation of that ventricle (18).

In patients with left ventricular hypertrophy a relationship has been described between the abnormal relaxation pattern of the left ventricle and the abnormal repolarization pattern in the precordial electrocardiogram (19). Hypothetically both abnormalities can be an expression of one underlying mechanism. Alternatively the abnormal diastolic wall motion might be the consequence of the abnormal process of repolarization.

In some patients without coronary heart disease the abnormal relaxation pattern of the left ventricle was preceded by an abnormal contraction pattern. The most outspoken examples are the 2 cases with left ventricular aneurysm, which were most likely of congenital origin (20,21). In a few of our patients no abnormal systolic wall motion 
could be visualized. An explanation could be the relatively low sensitivity of contrast angiography and echocardiography to diagnose these abnormalities as has been shown in cases with cardiac contusion (22).

\section{$\overline{\text { CONCLUSION }}$}

It can be concluded that several mechanisms like temporary or persistent myocardial damage of different etiologies, intraventricular pressure elevation and repetitive abnormal ventricular activation may result in a transient or persistent pattern of abnormal $S T$ segment and inverted $T$ wave in leads $V_{2}$ to $V_{4}$ without QRS changes. However there are (some) patients showing these electrocardiographic pattern without any obvious cause.

It is important to know that the described ST-T segment abnormalities in the precordial leads may be present, transiently or persistently in many different clinical situations to avoid mislabeling the patient as suffering from coronary heart disease.

A careful history, followed by physical examination allows correct identification of the underlying cardiac or non-cardiac abnormality in most patients. When needed a definite diagnosis can be made by using the appropiate non-invasive and invasive methods.

\section{AEFERENCES}

1. de Zwaan C, Bär FW, Wellens HJJ:

Characteristic electrocardiographic pattern indicating a critical stenosis high in left anterior descending coronary artery in patients admitted because of impending myocardial infarction. Am.Heart J. 1982; 103: 730-735.

2. de Zwaan C, Bär FW, Janssen JHA, Cheriex EC, Dassen WRM, Brugada P, Penn OCKM, Wellens HJJ:

Angiographic and clinical characteristics of patients with unstable angina showing an electrocardiographic pattern pointing to a critical narrowing in the left anterior descending coronary artery. Am.Heart J.; in press.

3. Ingels NB Jr., Daughters GT, Stinson EB, Alderman EL:

Evaluation of methods for quantitating left ventricular segmental wall motion in man using myocardial markers as a standard. Circulation 1980; 61: 966-972.

4. de Zwaan C, Cheriex EC, Braat SHJG, Stappers JLM, Bauer LHB, Wellens HJJ: Left ventricular wall motion in patients treated for unstable angina showing an electrocardiographic pattern pointing to critical narrowing in the proximal left anterior descending coronary artery.

Submitted for publication. 
5. Pruitt RD, Klakeg CH, Chapin LE:

Certain clinical states and pathologic changes associated with deeply inverted $T$ waves in the precordial electrocardiogram. Circulation 1955; 9: 517-530.

6. Wilson FN, Mc Leod AG, Banker PS, Johnston FD:

The determination and the significance of the areas of the ventricular deflections of the electrocardiogram. Am.Heart J. 1934; 10:46-52.

7. Franz MR, Bargheer K, Raffenbeul W, Haverich A, Lichtlen PR:

Monophasic action potential mapping in human subjects with normal electrocardiograms: direct evidence for the genesis of the $T$ wave. Circulation 1987; 75 : $379-386$.

8. Spodick DH:

$Q$ wave infarction versus ST infarction. Nonspecificity of electrocardiographic criteria for differentiating transmural and nontransmural lesions. Am.J. Cardiol. 1983; 51:913-915.

9. Koskelo P, Punsar S, Sipila W:

Subendocardial haemorrhage and ECG changes in intracranial bleeding. Brit. Med.J. 1964; 1: 1479-1480.

10. Connor RCR:

Heart damage associated with intracranial lesions. Brit.Med.J. 1968; 3: $29-31$.

11. Page A, Boulard G, Guerin J:

Anomalies electrocardiographiques au cours des hemorragies sous-arachnoidiennes. Arch.Med.Coeur 1983; 76: 1031-1038.

12. Geft JL, Shah PK, Rodriquez L, Hulse S, Maddahi J, Berman DS, Ganz W:

$S T$ elevations in leads $V_{1}$ to $V_{5}$ may be caused by right coronary artery occlusion and acute right ventricular infarction. Am.J.Card. 1984; 53: $991-996$.

13. Winkle RA, Lopes MG, Goodman DJ, Fitzgerald JW, Schroeder JS, Harrison D: Propanolol for treatment with mitral valve prolapse. Am.Heart J. 1977; 93: 422427.

14. Malcolm AD, Chayen J, Cankovic-Darracott S, Jenkins BS, Webb-Peploe MM: Biopsy evidence of left ventricular myocardial abnormality in patients with mitral leaflet prolapse and chest pain. Lancet 1979; I-II: 1052-1055.

15. Rosenbaum MB, Blanco HH, Elizari MV, Lazzari JO, Vetulli HM:

Electronic modulation of ventricular repolarisation and cardiac memory. In Frontiers of cardiac electrophysiology; Rosenbaum MB. Elizari MV (Eds) Boston; Martinus Nyhoff, 1983; 67-99. 
16. Chatterjee K, Harris A, Davies G, Leatham A:

Electrocardiographic changes subsequent to artificial ventricular depolarization. Br.Heart J. 1969; 31: 770-779.

17. Della-Bella P, Grazi S, Cipolla CM, Fabbiocchi F, Rimondini A, Sganzerla P, Guazzi MD:

Increased cardiac electrical instability concomitant with pacing induced repolarisation abnormalities. Br.Heart J. 1987; 57: 118-124.

18. Marcus FI, Fontaine GH, Guiraudon G, Frank R, Laurenceau JL, Malerque C, Grosgogeat $\mathrm{J}$ :

Right ventricular dysplasia: in report of 24 adult cases. Circulation 1982; $65: 384-$ 398.

19. Moore RB, Shapiro LM, Gibson DG:

Relation between electrocardiographic repolarisation changes and mechanical events in left ventricular hypertrophy. Br.Heart J. 1984; 52: 516-523.

20. Gueron M, Hirsch M, Opschitzer J, Mogel P:

Left ventricular diverticulum and mitral incompetence in asymptomatic children. Circulation 1976; 53: 181-186.

21. Singh A, Katkov H, Zavorak JH, Jane SM, McLeod JD:

Congenital aneurysms of the left ventricle. Am.Heart J. 1980; 99: 25-32.

22. Hossack KF, Moreno CA, Vanway CW, Burdick DC:

Frequency of cardiac contusion in nonpenetrating chest injury. Am.J.Cardiol. 1988;

61: 391-394. 


\section{$\overline{\text { Summary }}$}

Life is short and the ant long; the occasion fleeting; experience fallacious and judgement difficult. Hippocrates.

The aim of this thesis was to investigate a subgroup of patients admitted to hospital because of unstable angina and showing an electrocardiographic pattern pointing to a critical narrowing in the proximal left anterior descending coronary artery.

In Chapter II we report upon the first experience with 26 patients. In spite of symptom control by medical therapy 12 of 16 patients who were not operated upon, developed an extensive anterior wall infarction soon after admission. Urgent coronary angiography was proposed to identify candidates for early revascularization.

In Chapter III the angiographic and clinical characteristics are deseribed of a larger study population of 180 patients with an impending anterior wall infarction. In 90 percent of cases the abnormal ST segment and inverted $T$ wave in the precordial leads normalized during follow-up. Data analysis suggested hibernation and stunning of the myocardium as the underlying mchanism of the electrocardiographic and angiographic abnormalities. Patients with a patent but severely diseased proximal $L A D$ without collateral circulation were at higher risk for suffering a myocardial infarction. Revascularization was effective in relieving signs of ischemia.

Chapter IV discusses the identification and prediction of risk of having a proximal LAD obstruction. Patients with demonstrable ischemia, as manifested by an abnormal ECG at rest, appear to have major benefit from reperfusion.

In Chapter V effect of anti-ischemic treatment on left ventricular wall motion was studied by serial echocardiography in 35 patients with unstable angina having the described typical electrocardiographic pattern. Seventeen revascularized and 18 medically treated patients demonstrated significant improvement in myocardial systolic and diastolic function when the M-mode and $2 \mathrm{D}$ echocardiographic study was repeated 2.2 months after admission.

Also these findings do suggest stunned and hibernating myocardium as the underlying mechanism of the observed electrocardiographic and echocardiographic abnormalities.

In Chapter VI 41 patients are analyzed having unstable angina and an abnormal ECG. Following treatment with a fibrinolytic agent there was retrospective evidence of a high incidence of coronary thrombosis (of $54 \%$ ) in these patients. A decrease in coronary obstruction was primarily observed in patients with a complete or subtotal stenosis and markedly diminished coronary flow. Improvement in coronary anatomy was not determined by clinical characteristics of the study population. Ischemic symptoms and the incidence of surgical or angioplastic intervention were not different in patients with or without a reduction in coronary stenosis severity after fibrinolytic therapy. 
In Chapter VII we indicate that the electrocardiographic "LAD pattern" of abnormal ST segment and inverted $\mathrm{T}$ wave in the precordial leads can also develop and sometimes disappear in many other situations like cardiomyopathy, mitral valve disease, pulmonary disease, rhythm and conduction disturbances or no disease. A careful history followed by physical examination can avoid mislabeling the patient as suffering from coronary artery disease. Several mechanisms like myocardial injury, intraventricular pressure elevation and repetitive abnormal ventricular activation were described as possible causes of the transient or persistent electrocardiographic abnormalities.

May be life will lengthen thanks to the hopefully non-fallacious experiences discussed in this thesis! 


\section{Samenvatting}

(Deze samenvatting is vooral geschreven voor hen die kennis willen nemen van de inhoud van dit proefschrift, doch niet medisch geschoold zijn).

In de laatste decennia vormen hart- en vaatziekten de belangrijkste oorzaak van ziekte en overlijden in de Westerse samenleving. Ziekten van de kransslagaders en van de grote slagaders maken hiervan het belangrijkste deel uit. In de laatste jaren hebben de kennis van dit lijden en de diagnostische en therapeutische mogelijkheden zich belangrijk uitgebreid.

Het hart is een spier die uit vier holten bestaat (figuur 1). De vier holten zijn in twee functioneel gelijke paren gerangschikt. Deze delen worden door een tussenschot, het septum, van elkaar gescheiden in een linker en een rechter harthelft. leder paar bestaat uit een dunwandige voorkamer (de boezem) en een dikwandige hoofdkamer (de kamer). Tussen de voorkamer en de hoofdkamer en tussen de hoofdkamer en de longen lichaamsslagader bevinden zich kleppen die er voor zorgen dat het bloed door het hart in een bepaalde richting stroomt.

Het hart is een pomp die er voor zorgt dat voldoende bloed door de kleine (de long-) en de grote (de lichaams-) circulatic stroomt. In rust pompt het hart iedere mi-
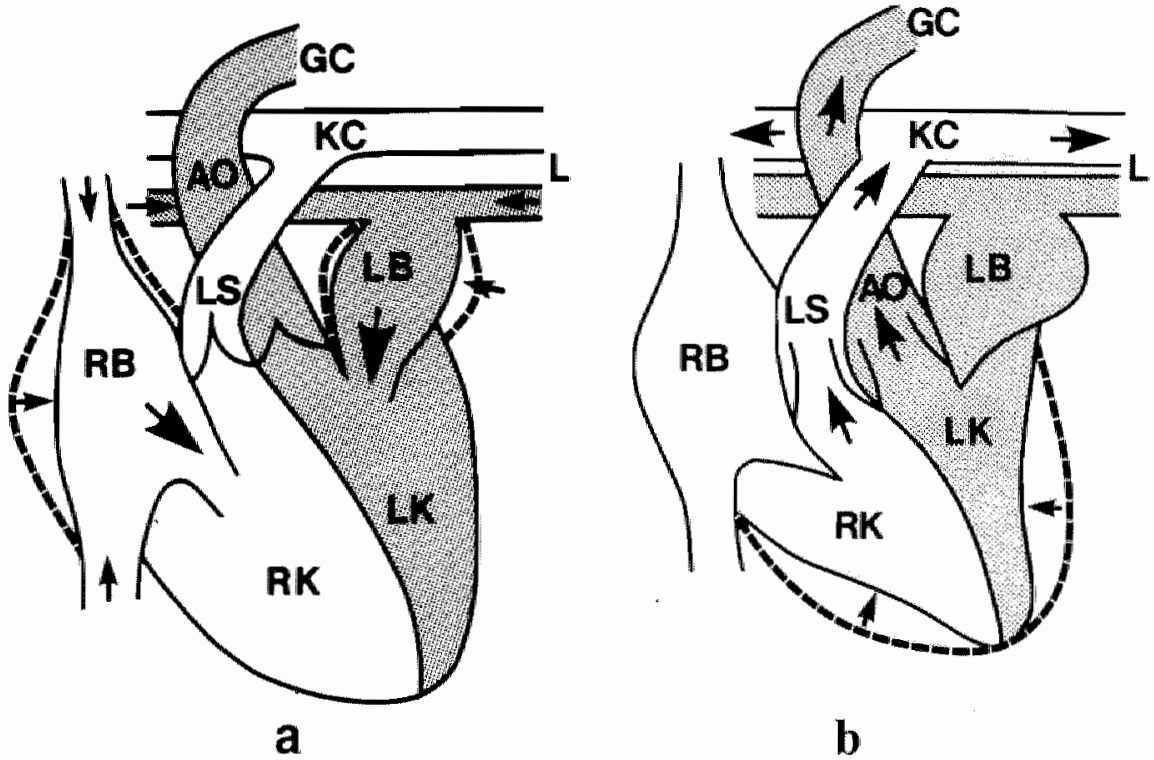

FIGUUR 1: Bloedstroom door de vier harthelften en door de kleine (de linker en rechter long-) en de grote (de lichaams-) circulatie via cen opeenvolgende samentrekkende beweging van de woorkamers (a) en de hoofdkamers (b).

$\mathrm{AO}=$ aorta; $\mathrm{GC}=$ grote circulatie; $\mathrm{KC}=$ kleine circulatie; $\mathrm{L}=$ longen; $\mathrm{LB}=$ linker boezem; $\mathrm{LK}=$ linker kamer; $L S=$ long slagader; $R B=$ rechter boezem; $R K=$ rechter kamer 
nuut ongeveer 5 liter bloed rond, bij inspanning kan dit oplopen tot 20 liter per minuut. Essentieel voor een goede pompfunctie wan het hart is dat eerst de voorkamers en daarna de hoofdkamers zich samentrekken. (figuur la en 1 b respectievelijk). Het signaal tot het samentrekken wan de hartspier wordt gegeven door een zwak electrisch stroompje dat hoog in de rechter boezem (in de sinusknoop) ontstaat. Deze electrische prikkel wordt via een gespecialiseerd type weefsel, het geleidingsweefsel, aan de overige hartonderdelen doorgegeven. Deze golf van electriciteit wordt gevolgd door de bovenbeschreven golf van hart-spiercontractie.

De energie behoefte voor het samentrekken van de hartspier is groot. De hartspier krijgt zijn energie via twee kransslagaders aangevoerd (figuur 2). De beide kransslagaders hebben hun oorsprong in de grote lichaamsslagader (aorta), vlak boven de overgang van de linker hartkamer naar de aorta. Een kransslagader voorziet voornamelijk de rechter harthelft van zuurst of en voedingsstoffen en heet de rechter kransslagader. De linker kransslagader splitst zich wlak na zijn oorsprong in twee takken. Een tak (de circumflextak) voorziet woor een belangrijk deel de achterzijde van de linker harthelft. De andere tak (de voorste afdalende tak) verzorgt de voorwand van de linker kamer en het grootste deel het kamertussenschot (het septum). Beide kransslagaders brengen behalve bloed naar de hartspier ook bloed naar het prikkelvormend- en prikkelgeleidingssysteem.

De beschreven golf van electriciteit over de hartspier kan door een apparaat worden opgevangen. De registratie hiervan heet het electrocardiogram.

De hartspiercontractie kan in beeld worden gebracht met behulp van geluidsgolven (vergelijkbaar met het sonarsysteem waarmee wordt bepaald hoever een boot van de zeebodem verwijderd is). Deze onderzoeksmethode heet echocardiografie.

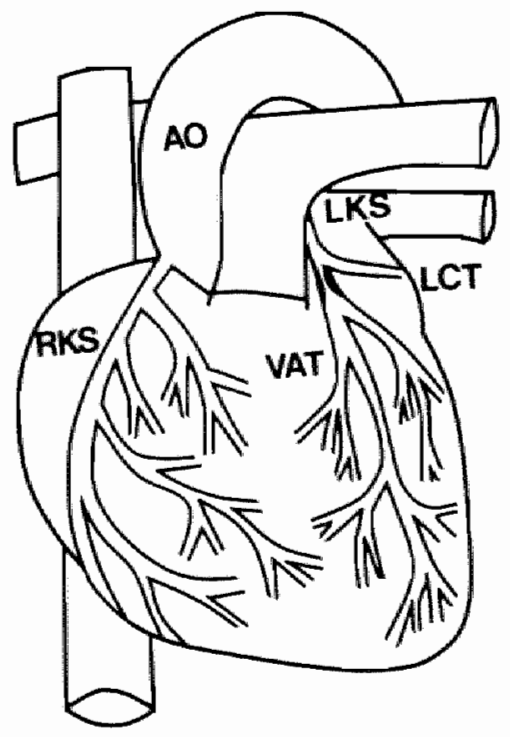

FIGUUR 2: De kransslagaders ontspringen vit de grote lichaamsslagader (de aorta). 
Daarnaast kan men via een invasief onderzoek (hartcatheterisatie) contraststof in de hartkamers spuiten, zodat de binnenkant en de knijpbeweging van het hart via röntgenstralen zichtbaar kan worden gemaakt. Laatstgenoemde techniek wordt ook toegepast bij het in beeld brengen van de binnenkant van de kransslagaders.

De wand van de kransslagaders kan om veelal onbekende redenen een dusdanige verandering ondergaan dat de doorgang verkleind en de doorstroming belemmerd wordt (figuur 3b). Een gevolg hiervan kan zijn dat het hart verstoken raakt van zuurstof en voedingsstoffen. Hierdoor kan de spier zich niet goed samentrekken, de golf van electriciteit zich niet goed voortbewegen en worden er zenuwvezels geprikkeld, waardoor de patiënt "pijn in de borst" ervaart ("angina pectoris").

Indien de doorstroming van zuurstofrijk bloed kortdurend belemmerd is, zoals bij "angina pectoris", zullen de genoemde gevolgen slechts tijdelijk zijn. Indien de doorstroming blijvend onderbroken wordt, zoals bij het hartinfarct, zullen de getroffen hartspier en het lokale geleidingssysteem ernstig en meestal blijvend beschadigd worden. De zenuwvezels in het infarctgebied zullen de patiënt net zo lang pijn bezorgen, totdat ze door een gebrek aan zuurstof definitief beschadigd zijn en geen pijnprikkels meer kunnen geven.

Is het hart echter matig lang verstoken van energie, zoals bij een zogenaamd dreigend hartinfarct, dan kan een hartkneuzing ontstaan. De schade kan voor een belangrijk deel door het lichaam hersteld worden. Net als bij een skeletspierkneuzing, zal dit herstel echter tijd vergen.

Via onderzoek dat is neergelegd in dit proefschrift, wordt aangetoond dat een groep van patiënten herkend kan worden die een dreigend hartinfarct heeft, waarbij de bloedstroom zodanig beperkt is (geweest), dat de hartspier wel gekneusd, doch niet definitief beschadigd is geraakt. Herkenning van deze groep vindt plaats via de ziektegeschiedenis van de patiënt en zijn electrocardiogram (hoofdstuk II). Laatstgenoemde onderzoekstechniek laat bepaalde afwijkingen zien die wijzen op een dreigende afslui-

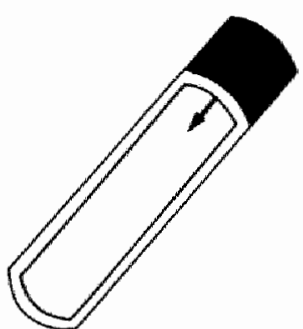

NORMAAL

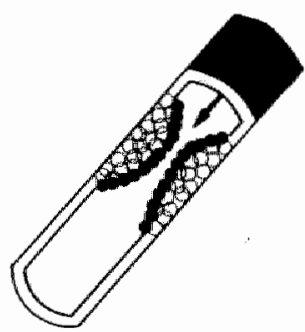

VERANDERDE WAND

b

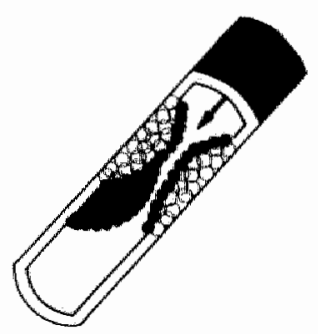

VERANDERDE WAMD

* BLOEDSTOLSEL

C

FIGUUR 3:

a) Doorsnede van een normale wand van een "gezonde" kransslagader.

b) Doorsnede wan een verdikte wand van een vernauwde kransslagader.

c) Als b, doch op de veranderde wand van de vernauwde kransslagader zit cen bloedstolsel. 
ting in het begin van de voorste afdalende tak van de linker kransslagader. Dit afwijkende patroon wordt veroorzaakt door een slechte bloedvoorziening van een belangrijk deel van het hart, te weten de voorwand en het harttussenschot.

Treedt er bij dit type dreigend hartinfarct een tijdig herstel op van bloed- en energievoorziening, dan ziet men dat de hartfunctie (de knijpbeweging) en de electrische activiteit van het hart (volgens het hartfilmpje) na meerdere dagen zich kunnen normaliseren. Beide waarnemingen werden gedaan via herhaald echo- en electro-cardiografisch onderzoek (beschreven in hoofdstuk III en V).

Treedt niet op tijd herstel op van de bloeddoorstroming en wordt de energievoorziening volledig geblokkeerd, dan ontstaat er alsnog definitieve schade en spreken we van een hartinfarct.

Het gevaar van de beschreven vernauwing in het begin van de voorste afdalende kransslagader is dus het grote risico op het krijgen van een uitgebreid hartinfarct of op overlijden (hoofdstuk IV). Dit risico is duidelijk groter dan wanneer deze vernauwing zich in een van de andere kransslagaders bevindt.

Een dreigend hartinfarct wordt onder andere veroorzaakt door het ontstaan van een vers bloedstolsel, dat zich net als bij een echt hartinfarct bovenop de reeds veranderde wand wan de vernauwde kransslagader vormt (figuur 3c). Een dergelijk stolsel kan via een stolseloplossend geneesmiddel worden verwijderd, waardoor de ernst van de vernauwing kan afnemen (hoofdstuk VI). Het is aan te nemen dat deze vorm van behandeling de bloedvoorziening van het bedreigde gebied kan verbeteren. De juistheid van deze aanname vormt het onderwerp van enkele onlangs gestarte onderzoekingen.

De meest zekere vorm van therapie van dit type dreigend infarct is anno 1989 echter het aanleggen van "een omleiding" of het oprekken van de kransslagadervernauwing (hoofdstuk III).

Is het in dit proefschrift beschreven patroon van het hartfilmpje uniek voor een ernstige vernauwing hoog in de voorste afdalende kransslagader? Het antwoord is nee. Men kan deze registratie ook zien bij andere hartziekten en bij sommige ziektebeelden die niet het hart betreffen (hoofdstuk VII). Deze bevinding benadrukt dat de diagnose van dit type dreigend hartinfarct niet alleen gesteld kan worden via het hartfilmpje doch mede gebaseerd moet zijn op de ziektegeschiedenis van de betrokken patiënt.

De bedoeling van dit proefschrift is om duidelijk te maken dat het op een goedkope manier door middel van een hartfilmpje en het klachtenpatroon mogelijk is om patiënten te herkennen met een ernstige vernauwing van een kransslagader waarbij een groot deel van de hartspier met afsterven wordt bedreigd. Het is noodzakelijk dat anno 1989 de hartspecialist goed op de hoogte is van dit beeld omdat een juiste behandeling deze catastrofe kan voorkomen. 


\section{Nawoord}

Bij het verschijnen van dit manuscript ben ik in de gelegenheid eenieder te bedanken die op enigerlei wijze heeft bijgedragen tot het tot stand komen van dit proefschrift.

Dit onderzoek is gedaan met hulp van velen, zoals ook aan het aantal mede-auteurs van de artikelen te zien is.

Prof Dr HJ』 Wellens gaf jaren en jaren vele ideeën voor dit onderzoek en was de drijvende kracht die er vertrouwen in moet hebben gehad dat het tot een goed einde gebracht zou worden. Hein, veel erkentelijkheid ben ik jou verschuldigd.

Mijn collega's werkzaam op de hartbewakingsafdeling, Ton Gorgels en Pedro Brugada, dank ik voor de wijze waarop zij de patiëntenzorg op zich hebben genomen, wat mij in staat heeft gesteld om elders aan het werk te gaan.

Het alhier beschreven, patiënt-gebonden onderzoek heeft wooral plaats gevonden op de hartbewakingsafdeling van het AZM. Ton Hofs en de verpleegkundige staf stonden borg voor een prima samenwerking.

Daarnaast wil ik de leden van de beoordelingscommissie bedanken voor het kritisch. doorlezen van dit proefschrift.

Nicole Cochrane in het bijzonder en Bea Leliveld hebben alle zorg besteed aan het typen van het manuscript en het uitvoeren van de talloze correcties die telkens weer moesten worden uitgevoerd. Ruud Leliveld was betrokken bij de laatste stappen die nodig waren om het manuscript in zijn huidige vorm te krijgen.

Ongetwijfeld zijn er meer mensen die recht thebben hier genoemd te worden en die mij hebben gesteund door hun adviezen en aanmoediging; ook hen ben ik dank verschuldigd.

Aan mijn familie denk ik op eigen wijze. 


\section{Curriculum vitae}

\section{Christoffel de Zwaian}

\begin{tabular}{|c|c|}
\hline Born & Amsterdam, January 31, 1947 \\
\hline Nationality & Dutch \\
\hline State & Married, 3 children \\
\hline $1966-1974$ & Medical School, University of Leiden \\
\hline $1974-1976$ & Internship, St. Jozef Ziekenhuis, Doetinchem \\
\hline $1976-1978$ & $\begin{array}{l}\text { Residency in Internal Medicine, Catharina Ziekenhuis, Eindhoven, } \\
\text { Head Dr JA Flendrig }\end{array}$ \\
\hline $1978-1981$ & $\begin{array}{l}\text { Residency in Cardiology, Ziekenhuis St. Annadal, Maastricht, } \\
\text { Head Prof Dr HJJ Wellens }\end{array}$ \\
\hline 1981 & Specialist in Cardiology \\
\hline 1982 & $\begin{array}{l}\text { Member of Staff of the Department of Cardiology, Academic } \\
\text { Hospital Maastricht, Chairman Prof Dr HJJ Wellens }\end{array}$ \\
\hline
\end{tabular}

